\title{
N. F. S. Grundtvig: Rim-Brev til Nordiske Paarørende, 1832. Tekstkritisk og kommenteret udgave
}

\author{
Af Flemming Lundgreen-Nielsen
}

"Rimbrev til Nordiske Paarørende", indledningsdigtet til Nordens Mythologi, 1832, genoptrykkes her med real- og sprogkommentarer til de 258 verslinjer, under hensyntagen til såvel 2 manuskripter i Grundtvig-arkivet og diverse udsagn i Grundtvigs egne omkringliggende tekster som tidligere forskeres behandlinger. Det påvises, hvor mangetydige og indforståede henvisninger Grundtvig som mytolog arbejder med. En Efterskrift sætter teksten som helhed ind i Grundtvigs verdslige forfatterskab på den tid, hvor han opstiller den humanistiske udviklingsrækkefølge "Menneske først og Christen saa". Udgivelsen demonstrerer også, at de så hyppigt citerede verslinjer om frihed for Loke så vel som for Thor og om livet på Jorden som en kamp og en kappestrid historisk set har en anden og mere nuanceret betydning end den, moderne brugere tillægger dem.

\section{Teksten}

Rim-Brev

til

Nordiske Paarørende

[I]

Sønner og Døttre af Nordens Aand:

Kæmpe-Vækkeren seiertryg,

3 Som lagde Fenris-Ulv i Baand, Pløiede Midgaards-Ormens Ryg, Reed over Ginnung-Gab i Spring,

6 Kiørde med Thurs og Trold i Ring, Stod under Aske-Kronen Maal, Veiede Guld saa godt som Staal,

9 Søgde det ei i Klippens Aarer, Søgde det før paa Havsens Bund, Fandt det saavel i Freyas Taarer

12 Som under Smil i Glaser-Lund; Malede Guld paa Grotte-Kværn, Saaede Guld til Lande-Værn,

15 Smedded deraf en Hammer dru, Tjenlig for Magn og Mod endnu, Knusde dermed den Røver-Haand,

18 Som lagde Herkules i Baand, 
Knusde dermed hvad Staal ei beed:

Jetten med Brev paa Evighed,

21 Knusde dermed det stolte Rom,

Som der skal evig kvædes om!

Sønner og Døttre af ham i Nord

$24 \quad$ Og af den Diis der græd for Balder!

Har I end Øre for Aandens Ord,

Hører det dog, en Broder kalder;

27 Lad dog et Svar ham lære brat, At ei i Fimbul-Vinternat

Han kun fik Rune-Maal for Een,

30 Som alle Kæmpers Bauta-Steen!

[II]

Græs har jeg fundet paa Danmarks-Vei,

Hvor Man ved Thoems det vented ei,

33 Sikkert ved Ex i det Danske Bjerg

Ogsaa der sidder en Gienlyds-Dværg;,

Knurrer ved Com i det Danske Taarn

36 End vel en Kæmpe, som kvad tilforn ${ }^{* *}$;

Men hvad der slumrer i Alfreds Grav

Hører ei Røsten, mig Dana gav,

39 Elve-Dronningen, daanet der,

Ikke mit Kvad om Herre-Færd!

Skjalde-Tungen mig hist i Mund

42 Er kun som Toner i Harpe-Bund,

Hvor Man ei kiender det Hande-Lag

Som til en Leg giør Harpe-Slag,

45 Og til at lalle paa Amme-Skiød

Er ikke længer min Tunge blød,

Men til, som Pogen, at nemme godt

48 Dertil er nu mit Haar for graat ${ }^{*}$ !

Løfter sig der min Stemme bold,

Giør kun paa Mur og Bom den Vold ${ }^{* *}$,

51 Kan ikke der paa fremmed Grund,

Svare sin Told i Øre-Sund!

\footnotetext{
$\left.{ }^{*}\right)$ Hvor Ruinerne af Rougemont Castle ved Exeter minder om de gamle Konger i VestSex, viser Man endnu Dansker-Bjerget, hvor vore Fædre stormede.

${ }^{* *}$ Dane-Borgen (The Danish Castle) ved Cambridge er nu et Fange-Taarn.

${ }^{*}$ Shakspear's King Richard the second. 1. 4.

${ }^{* *}$ Med Rette sagde derfor mine Venner i Cambridge om mig: he speaks English thro' a stone-wall!
} 
[III]

Men er det mueligt, skal jeg troe,

54 Her i de gamle Glaser-Lunde, Dødning-Ridt over Gjallar-Bro

$\mathrm{Nu}$ kun huger fra Skjalde-Munde;

57 Her ei kan svulme et Kæmpe-Bryst, Her ei kan lyde en Nordisk Røst, Uden Man hvidsker brat under Øe:

60 Hør, hvor den vilde Hervor-Mø Kogler og vækker til nyt Ustyr Hjorvard, Hrane og Angantyr!

63 See, hvor det gnistrer i bælgmørk Nat! Kors, nu dages vel Tyrfing brat! Kommer og lugter det christen Blod,

66 Aldrig der raades paa Vaanden Bod?

[IV]

Hvad? er al Kraft da Jetters nu, Saa intet Staal har meer Guld-Fæste!

$69 \mathrm{Hel}$, der i Nord var før en Gru, Er nu af Diser hun den Bedste! Løve-Hoved paa Klinge-Klodd!

72 Følger ei meer Du Egg og Od! Eller blev nu Man i Thrud-Vang selv Ræd for lidt Gny af Glommens Elv!

75 Hvad? I Kyster ved Bælt og Sund, Bøge-Kæmper med Sang i Mund! Klippe-Væggen med Rune-Stav,

78 Hrone-Klinten med Bjovulfs Grav! Guld-Sædevang fra Heden-Old, Bauta-Steengiærde om Fyrresvold!

81 Mjøsen og Dovre og Guldbrandsdal, Høi efter Hølge og Seng for Hval! Trylle-Navne blandt Folk i Nord!

84 Er I nu alle kun tomme Ord? Levned paa Marken os Hengst og Hors Sværmere kun for Klør og Pors,

87 Pære-Skuder og Flynder-Skind, Fløde-Bøtte og Pølse-Pind? Levnede Volse i Gøthe-Skov

90 Kulsvier kun og Kulfust grov, Øie for Gruus, for Græs og Snegl, Argus-Øine for andres Feil?

93 Levned dig, Norge, med Klipper graa Rolv kun Nisser fra Top til Taa, Vente-Brev paa en Engelsk Bill,

96 Storthings-Drømme og Throndhjems-Sild? 
Vandred I ud, eller sank i Muld

Alle, som gløded for Oldtids Guld,

99 Ahned i Odin meer end Luft,

Andet i Aand end tydsk Fornuft,

Andet i Friggas Graad for Balder

102 End hvad der fugter naar Duggen falder,

Mere i Myther end Æventyr,

Andet i Folk end kloge Dyr,

105 Mere i Kamp end Knald og Fald,

Andet end Skin i Odins Hald,

Mere i Liv end Lykke-Spil,

108 Andet end Gas i Ygdra-Sill?

[V]

Nei, ikke saa, det vist jeg veed,

Hel-Veien nok var altid breed,

111 Immer blandt Folk i Tidens Løb

Hunde-Forstand var Røver-Kiøb;

Derfor til Helte Man fandt en Hald,

114 Tog selv i Nord paa Skjalde Tal,

Mens uden Tal, som uden Navn,

Skiftinger sank i Helas Favn;

117 Men hvor saa vid blev Valhalds Port,

Som vi det seer paa Grimners-Maalet,

Og dog de Portes Tal saa stort,

120 At det af Prim-Stav ei er stjaalet; ${ }^{*}$

Hvor der blev Kæmpe-Viser fleest

Var dog af Kraft og Skjaldskab Meest,

123 Og hvor Man sang de Viser bedst,

Sikkert faae Kæmper en Valhalds-Fest,

Opskærs-Gilde i AEgers Sal,

126 Naar der indhøstet er paa Val.

Steen-Stuen feiet med Laurbær-Kost,

Bægeret fyldt med Idunnas Most!

129 Ja, hvor med Lyst de Piger smaa,

Som lode siden Vugger gaae,

Lytted til Kvad om gamle Nord,

132 Vinge-Vølund og Age-Thor,

Der vist leger nu mangen Pog

Ind sig i Nordens Billed-Sprog,

135 Der vist mangen en Unger-Svend

Ønsker sig Kæmpe-Sværd ved Lænd!

${ }^{*}$ Der var, som Man veed, ikke mindre end 540 Dørre paa Ærens Nordiske Tempel, og hver af dem saa vid, at der kunde gaa 800 Kæmper javnsides, hvad Man strax seer, giør høiere Tal, end der var i de Islandske Almanakker (PrimStave) hvori Man ellers vil have opdaget Kilden til alle vore Myther. 
[VI]

Derfor, I Børn af Kæmpe-Æt!

138 Hører mig dog, forstaaer mig ret!

Tungen er Sværd og Pennen Spyd, Skjoldet er Vidd og Daaden Dyd,

141 Slaget giælder kun Last og Skam, Hunde-Sjæle i Folke-Ham, Dem der gnave paa Askens Rod,

144 Skylle kun Bleer i Kvasers Blod, Dem der trampe paa Bifrøst-Bro Grovt med en Lap af Lokes Sko,

147 Dem der trumfe hvor Aser boe Bredt i Bord med en Hrungner-Kno, Drikke derpaa syv Boller Puns,

150 Asgaard og Valhald skal gaae tilbunds, Freya og Sifkun finde Havn, Ved deres Gunst i Jette-Favn,

153 Sif til at sidde i Hald paa Stads, Vanehjems Diis til Spas og Fias, Mens alle Guder med Spot og Spee

156 Nævnes kun der, hvor Nisser lee! Dem kun giælder vort Hammer-Slag, Alt som i Gaar, til Domme-Dag,

159 Deres Pande faae Last og Skam, For de misbruge vor gode Hamm; Men deres Blod har ingen Nød,

162 Smøre vi vil os ei paa Kiød, Ikke engang bruge Risp og Syl, Mod deres Gnæggen, Bjæf og Hyl,

165 Kun bruge Mund, som vi kan bedst, Over dem age med Thor i Sky, Springe dem over paa Odins Hest

168 Naar vi engang ride Sommer ad By, Lade dem seile der' egen Sø, Drømme sig drukne af Lethes Gammen,

171 Mens vi, ombord med Njord og Frø, Seile til Luv dem sønder og sammen; Lade dem ride i Jotun-Kraft,

174 Baade paa Grissel og Koste-Skaft, Ride paa Kaal-Stok, Hør og Hamp, Rene Former og Gas og Damp,

177 Ride til Bloks-Bjerg og til Troms, Der at sidde med Thrym til Doms, Der at thinglyse for Thurs og Trold:

180 Age-Thor ret er en vanskabt Knold, Værd kun at bruge til Hulvei-Fyld, Var det ikke for Mjølners Skyld! 
183 Odin primer, den Sag er reen,

Og da hans Hest bruger otte Been,

Skam han kun har af de store Spring

186 Med en saa unaturlig Ting!

Frey vel skinner i Ælve-Sal

Er dog immer en Maanskins-Ka'l,

189 Kiøbde sig Kys for Guld og Sværd,

Er ei et Gran af sin Lykke værd!

Ælve-Kongen et Skib ham gav,

192 Ælve-Piger et Taare-Hav,

Stout han seiler, men uden Roer,

Uden Bestik og Lods om Bord,

195 Kommer i Land men kun med Skam,

Kun som et Lykkens Dægge-Lam!

Balder alene, ja han er sød,

198 Salig at prise, thi han er $d ø d$ !

[VII]

Ja, I Sønner af Kæmpe-Æt!

Lad os forstaae vor Fordeel ret!

201 Slagne vi er over hver sin Læst,

Frihed er hvad os tjener bedst,

Frihed, men ikke som Ild og Vand,

204 Pest og Hunger og Ødeland,

Frihed, men ikke som Ulv og Bjørn,

Ikkun som voxne Menneske-Børn,

207 Og som den sig med sund Forstand

Rimer i Øine-Forblindelsens Land, Hvor vel ei Stif-Moder Ulv og Bjørn

210 Skaber nu meer af umyndige Børn,

Men hvor Endeel, som af Dyr har Mest,

Blev dog tilsyne som Folk er flest,

213 Kan ei begribe, hvad Frihed er til

Uden at giøre det Onde Man vil, Hevne sig frit, ei paa Uvenner blot

216 Men paa dem alle, som har det godt,

Og mellem Dyr tør broute af

Aandelig Byrd og Adelskab!

219 Frihed lad være vort Løsen i Nord,

Frihed for Loke saavelsom for Thor,

Frihed for Ordet i Verdenen ny,

222 Som til sig selv det har skabt under Sky:

Tankens og Troens og Vidskabens Land,

Ligest af synlige Ting dog en Strand,

225 Hvor kun i Blæst Man seer Bjerg-Toppen hvid,

Og hvor kun Livet sig rører i Strid,

Hvor, selv naar Kraften sig hyller i Damp,

228 Lydt den udraaber: mit Liv er i Kamp! 
Tankens og Troens og Vidskabens Hav, Som uden Frihed er Asernes Grav,

231 Men, som, naar Kræfterne kappes om Rang,

Ligner en blomstrende, bølgende Vang, Pranger med Borge og skyhøie Bjerge,

234 Vrimler af Aser og Alfer og Dværge, Hæver sig over hvad Hænder kan naae, Og selv hvad Ørnen i Høiheden saae,

237 Vækker, som Asernes Odel i Nord, Ære-Frygt dyb for det levende Ord! Kalde det Frihed kun hvo som har Lyst

240 Fenris at løse til Ragnaroks-Dyst, Naar dog ei Fenris, men Faderen kun, Vinder Forlov til at bruge sin Mund!

243 Fri være Loke, som Brage og Thor! Jetter kun fængsler det vingede Ord, Kamp-Guder alle, som drilles med Vid,

246 Vækkes af Dvale til seierrig Strid! Frihed for Alt hvad der stammer fra Aand, Som ikke ændres men arges ved Baand,

249 Virker skinbundet det Værste i Løn, Tæmmes alene ved Thor-Karmens Døn! Derfor, I Ædlinger! fjerne og nær,

252 Lad os ei strande paa Særhedens Skiær, Men kun bestride med Ord og med Aand Hvad ei kan røres og gribes med Haand!

255 Bundet kun være det glubende Dyr, Som i sit Svælg vil det Ædle begrave! Eenarmet stander med Æren da Tyr, 258 Magtesløs spotter kun Loke den Brave!

\section{Noter}

Tallene angiver nummer på verslinje i teksten.

De kendteste navne fra nordisk mytologi er gengivet i den almindelige danske form, mindre kendte navne bringes i normaliseret vestnordisk form. De præcise kilder, Grundtvig har benyttet overalt i Nordens Mythologi, er til overflod oplyst i hans egne talrige fodnoter og gentages ikke her, hvor kommenteringen ikke har filologisk sigte, men først og fremmest søger at skelne mellem generelt tilhørsforhold til Snorre, enkelte eddakvad eller Saxo. Snorrehenvisninger og henvisninger til Völuspá går derfor på den grundlæggende trykte udgave ved P. H. Resen i 1665, som Grundtvig også har kendt og brugt (US V, 472, 492-493, jf. originale fodnoter). Eddakvad er lokaliseret med strofenummerering fra Martin Larsens danske oversættelse af Den celdre Edda, 1943-46, sammenholdt med Jón Helgasons moderne tekstkritiske udgaver. Saxo er konsulteret i Karsten Friis-Jensens udgave fra 2005 med revideret optryk af Peter Zeebergs danske oversættelse (fra 2000), med sideblik til Stephanus Stephanius' grundlæggende tryk fra 1644 med 
kommentarbind året efter, som Grundtvig ligeledes har kendt (US V, 469, jf. mange originale fodnoter).

Titlen: Rim-Brev] om den litterære genrebestemmelse, se Efterskrift.

Titlen: Paarørende] slægtninge. Ordet har dobbelt betydning, dels den elementære, at de nordiske folk er frænder og naboer i oldtid som i nutid, dels den specifikke, som Grundtvig redegør for i sin Indledning til Nordens Mythologi, at efter sine Englandsrejser 1829-31 er han blevet klar over, at Norden også omfatter England. Han taler terminologisk om en nydansk historisk-geografisk genoptagelse af det oldnordiske ord og begreb "dansk", dækkende området "fra Eideren til Tromsøe, og fra Vester-Havet til den Finske Bugt (...) over Havet til de Nordiske Udfløttere paa Herkules-Øen" (US V, 399). Skønt englænderne har fortrængt det danske og ikke umiddelbart har villet lytte til ham, taler dog stadig historiske minder og stednavne fra anglernes og vikingernes tid om arven (jf. Grundtvig US V, 453-459, 507) og han har mærket en vis forkærlighed for at betegne noget (godt) som dansk $\left(502\right.$, note $\left.{ }^{* *}\right)$. I 1838 udleder Grundtvig engelsk væsen af, at englænderens fader er angelsakseren, og mener, at erobringen af England er den eneste, danskerne har haft lyst og lykke til at gøre (MM, 458-459). Grundtvigs digt “Ægers-Gildet i Engeland", trykt i Danskeren IV, 5. juli 1851 (PS VII, 443454), hylder endog England som mulig og ønskværdig fuldførelse af de nordiske rigers trekløverblad til et firkløver, "Lykkens Tegn og Pant". Ægirs "Hall" er et "Krystal-Palads" (nævnt hele 3 gange, jf. J. Paxtons glasdrivhus på $92.000 \mathrm{~m}^{2}$ på verdensudstillingen i London samme år), og han selv må som havets indfødte vætte være engelsk. Desværre er Ægir gift med jættekvinden Ran, der er skyld i den engelske flådes vanry i Norden, men det kan annulleres, hvis han genopfrisker Nordens asamål og sin barndoms vuggeviser hos "Angelboer og Friser" i Slesvig. Grundtvig nærer en veritabel Englandsforelskelse. Poul Borum opfatter "Paarørende" mere alment som "rette Vedkommende" (Borum 1983, 56). Det ældste manuskript til teksten, A, har overskriften "Til / Nordens Kæmpe-Børn", der så rettes til "Nordiske Paarørende", idet ordet "Riim-Brev" sættes foran (Fasc. 388.135).

1 Døttre] skønt rimbrevet reelt mest vægter mandlig heltedåd, er det bemærkelsesværdigt, at Grundtvig fra først af har kvinderne med i sin optik (jf. v. 23 og det kønsubestemte "Børn" (v. 137), "MenneskeBørn” (v. 206), “Ædlinger" (v. 251), ligesom det endelige titelord "Paarørende" er en familiebetegnelse med varm klang).

2 Kæmpe-Vækkeren] den, der vækker helte, jf. Saxos latinske gendigtning af Bjarkimál, Gesta Danorum, Liber II,7,4-7,28; udtrykket er her brugt om Nordens Aand. Allerede i 1810 havde Grundtvig forfattet en da utrykt "Vækker-Sang" (US II, 42-44, titlen er dog Svend Grundtvigs, PS I, 188), hvor han anså nutiden for åndeligt at være faldet i søvn (str. 4). Senere i Nordens Mythologi betegner Grundtvig Stærkodders Ingjaldskvad hos Saxo (Liber VI, 9,3-9,16) som "den hjemmegjorte Veekker-Saga" modsat det angelsaksiske Beowulfskvad (US V, 741). seiertryg] sejrsikker (jf. v. 246: "seierrig Strid"). 
3 Fenris-Ulv i Baand] Fenris-ulven var søn af jætteparret Loke og Angrbóða, som ifølge Snorres Edda (Resen 1665, fabel 29) blev lænket af aserne, hvorved guden Tyr mistede sin højre hånd, der lå som pant $\mathrm{i}$ uhyrets mund.

4 pløiede Midgaards-Ormens Ryg] Midgårdsormen var en anden søn af Loke og Angrbóða; ifølge Snorres Edda (Resen 1665, fabel 42) og det fragmentarisk overleverede eddakvad Hýmiskviða søgte guden Thor på en fisketur med jætten Hymer at hale Midgaardsormen op fra havets bund og kan således billedligt siges at have pløjet ormens ryg med bådens køl.

5 Reed over (...) i Spring] springet kendes ikke i den nævnte forbindelse, men da Balder er blevet dræbt, rider den tapre Hermod, søn af Odin, på sin faders hest til dødsriget og dødsgudinden Hel for at få ham frigivet og kommer med et voldsomt spring over porten til Hels borg (jf. Resen 1665, fabel 44: "Hesten sprang saa hart offver Trallvercked, at hand rørde icke det mindste der ved med sine Fødder”, jf. senere i Nordens Mythologi, US V, 600).

5 Ginnung-Gab] det tomme svælg mellem tågeverdenen og flammeverdenen før Jordens skabelse (Resens Voluspa 1665, str. 3).

6 Kiørde (...) i Ring] kørte rundt med; forvirrede; narrede (humoristisk udtryk for overlegenhed). Udtrykket kan dels gå på fysiske kampe, dels på intellektuelle samtaler med gådegætning (jf. Begtrup 1907, 109).

6 Thurs og Trold] store og stupide væsener, nærmest synonymer for jætte; Grundtvig henviser formentlig til det generelle misforhold mellem jætter og ase- og vaneguderne, næppe til en bestemt begivenhed.

7 stod (...) Maal] levede fuldt ud op til forudgivne funktioner. Manuskript A har her i samme betydning: "holdt (...) Maal" (Fasc. 388.135).

7 under Aske-Kronen] kronen på asketræet Ygdrasill, som ifølge eddakvadet Grímnismál, str. 29-35, er det største og helligste træ i verden, der efter eddakvadet Völuspá skal skælve ved Ragnaroks komme (Resen 1665, fabel 14 og 48, samt Resens Voluspa 1665, str. 44). Træet kaldes i Völuspá str. 2 for "mjötviðr", hvad der skal betyde måltræet, dvs. det efter godt mål dannede træ eller det grænsesættende træ (anderledes Grundtvig US V, 529-530). Ifølge sammenhængen skal verslinjen nævne et positivt træk ved Nordens ånd. Udtrykket kan derfor næppe henvise til Balders død som mål for misteltenen i asernes kappestrid for at understrege hans usårlighed; desuden taler ingen kilder direkte om, at drabet foregik under Ygdrasill, selv om det generelt siges, at gudeforsamlinger (ting eller domstol) dagligt holdtes under verdensaskens tredje og himmelske rod (Resen 1665, fabel 14). Snorre meddeler dog, at Loke gik "til things" med den fatale mistelten og der traf den blinde Høder yderst i kredsen af guder (Resen 1665, fabel 43, jf. US V, 610). Sprogligt ville en tolkning af "mål" som "sigtepunkt, genstand" i forbindelse med verberne "stå" eller "holde" være uden andre belæg.

8 Veiede] vejede, vurderede, satte pris på; her vel snarere: omgikkes med, håndterede. 
8 Guld (...) Staal] næppe hentydning til nogen bestemt myte, de to metaller kan henholdsvis stå for skønhed og værd og for kraft og hårdhed, måske også for egenskaber tillagt aser og jætter hver for sig.

9 Klippens Aarer] underjordiske huler og lokaliteter er i nordisk mytologi gerne jætte- og/eller dødsriger, og minedrift er derfor næppe et positivt begreb. Det kan hentyde til grubleri, dybtgående filosofi med teoretiske spekulationer (jf. Begtrup 1907, 110). I digtet "Et Blad af Jyllands Rimkrønike" i Heimdall, 1816, skriver Grundtvig om Freja: "I Taaren Ædelstenen groer / Og ei i Fieldets Aarer" (str. 176, US III, 229).

10 paa Havsens Bund] måske indirekte hentydning til Phaëtons endeligt i floden Eridanos efter en løbskkørsel med faderen Helios' solvogn; hans søstre (heliaderne) græd tårer, der blev til rav, og druknede sig af sorg i de samme bølger. Grundtvig mener, at Eri-Danos er Østersøen (Grundtvig 1875, 242, Anmærkning fra 1829) eller en forvansket form for Øresund (jf. Toldberg 1950, 162-163 samt 272, teksten til note 118). I Haandbog $i$ Verdens-Historien, II, 1836, knytter Grundtvig sammenhæng mellem Eri-Dan-floden, Phaeton, Freja og Ottar og de salige øer i Norden, hvis udødelighedsbegreb var hjemlet af genlydende "Skjalde-Sang om alle de hedenfarne Ædlingers Gammen i det grønne Gudhjem" (US VI, 593), en absolut ugræsk forestilling.

11 Freyas Taarer] i Snorres Edda (Resen 1665, fabel 30) græder kærlighedsgudinden Freja gyldne tårer over sin forsvundne ægtemage, Óttar, jf. det dunkle eddakvad Hyndluljóð og Grundtvigs frie digtning herover i "Et Par Ord i Anledning af det forkyndte Sørgespil: Signe", 1807 ( Ny Minerva 1807, 255) (jf. Toldberg 1950, 158-161 med citat af Signe-artiklen 295 , teksten til note 16 ).

12 Smil i Glaser-Lund] Glæsisvellir, mytisk stednavn i Hervarar saga ok Heiðreks, kap. 1, hvor en beundret kong Godmund (Gudmund) regerede på så kløgtig en vis, at stedet fik ry for at være blottet for død, sygdom og ælde, en Ódáinsakr (jf. Grundtvig i PS I, 442, tekst fra 1809, trykt i Idunna. En Nytaarsgave for 1811, 1810, sammesteds 512 står der fra det helt omarbejdede optryk i Nordiske Smaadigte, 1838, "Gloesmarken", jf. Nordens Mythologi, US V, 733-735). Grundtvig fordansker djærvt stednavnet til "Seilivs-Vangen" (734). Det forekommer også i eddakvadet Helgakviða Hjörvarðssonar, str. 1 (jf. "Kong Hjørvards Bopæl" i Norge, Magnusen 1823, 305), og hos Saxo i Hamletsagnet som "Undensakre" (Liber IV, 2,1, jf. Stephanius $1645,104)$. Grundtvig nævner tidligt, at Freja med smil genfinder sin elskede ("Et Blad af Jyllands Rimkrønike" i Heimdall, 1816 (US III, $229-230)$; $i$ en originalnote mener Grundtvig (228, note ${ }^{* *}$ ), at de danske øer er identiske med de "glesseriske" rav-øer nordpå ("GlerØerne"), nævnt i antikken (blandt andet Plinius' Historia naturalis, Liber IV, xxxiii,97: "Glaesaria"). I Eiríks saga vífförla bruges Ódáinsakr om det bibelske paradis (Vigfússon 1860, 29). "Gler-" er i øvrigt "glar-, glas-"; keltisk overlevering taler om "insula vitrea" (Vries 1957, 285, note 4). Senere i Nordens Mythologi citerer Grundtvig Snorre for beskrivelsen af "Gloser-Lunden" (US V, 735). 
Kong Gudmund optræder også hos Saxo i Thorkil Adelfars 1. ekspedition til underverdenen højt oppe ad Nordpolen til (Liber VIII, 14,7-11 og 19), jf. gendigtningen i danske knittelvers i Rimkrøniken, 1495 (Toldberg 1961, 71-73).

13 Grotte-Kværn] jættekvinderne Fenja og Menja malede ifølge eddakvadet Grottasöngr guld til kong Frode på en kværn kaldt Grotta (Resen 1665, fabel 66).

14 Saaede Guld] efter et besøg hos den svenske kong Adils red Rolf Krake og hans mænd hjem med guld og smykker taget fra svenskerne, men da danskerne blev forfulgt af disse, strøede de byttet ud på marken Fyrisvöllr, så svenskerne, Adils medregnet, standsede for at samle det op, og undslap således. Tildragelsen giver anledning til guldkenningen "Krakes sæd" og "Fyrisvolls frø" (Resen 1665, fabel 64 samt kenningeregistret under "Gull", nr. 23-24) (jf. også Saxo Liber II, 6,6-6,7). - V. 13-14 mangler i manuskript A (Fasc. 388.135).

14 til Lande-Værn] som forsvar, for at forsvare sig.

15 Hammer] Thors hammer Mjølner (Mjöllnir) blev ifølge Snorres Edda (Resen 1665, fabel 59) smedet af dværgeparret Eitre (ellers Sindre) og Broke, men da Loke i skikkelse af en flue generede Brokes arbejde ved blæsebælgen, fik den kort skaft og blev en hammer i stedet for en stridsøkse. Snorre skriver dog, at hammeren er smedet af jern, så det er Grundtvig, der gør den til guld for at få understreget modsætningen til "Staal" i v. 19. Senere i Nordens Mythologi fremstilles den dog af "Staal" (US V, 628). Begge manuskripter, A og B (Fasc. 388.135136), har her i stedet for v. 15-16 linjerne: "Smedded deraf en Kiølle god, / Svang den paa Val med Kraft og Mod,". Stedet har således oprindeligt henvist til kong Gram hos Saxo (Liber I, 4,2 og 4,12), der for at ligne en jætte og kunne skræmme folk gik rundt med en kølle (på latin "clava"); Vedel oversætter det først til en "Kempe staff", siden, da den forgyldes for at imødekomme en spådom, til "en Kølffue met it Guldhoffuit" (Vedel 1575, VI-VII), Grundtvig har i sin 1818oversættelse skrevet "Kiølle" (i græsk mytologi har helten Herakles i øvrigt en vældig kølle af oliventræ som sit yndlingsvåben).

15 dru] drøj; kraftig; god.

16 Magn og Mod] Thor har med jættekvinden Jarnsaxa sønnen Magni (= magt) og med sin hustru Sif sønnen Móði; Magni hjælper sin fader, da denne har fældet jætten Hrungner (Resen 1665, fabel 55), og begge halvbrødre hører til de guder, der ifølge Snorres Edda (Resen 1665, fabel 49) efter Ragnarok skal leve på Idasletten. De skal sammen arve Mjølner, når Thor er blevet dræbt (eddakvadet Vafbrúđnismál, str. 51). I Christenhedens Syvstjerne. Et Kirkeligt Sagakvad, 1860, nævnes Mod og Magne som hammersvingere i den angelsaksiske menighed (95).

17 Røver-Haand] romerne som besættelsesmagt i England (år 43-410). Den følgende mellemperiode prægedes af en opdeling af landet $i$ adskillige små riger (de største var i dominans-orden Northumbria, Mercia, Wessex og vikingesamfund). I 1013 erobrede Svend Tveskæg England, og hans søn Knud den Store slog bedriften fast i 1016, 
hvorefter England indtil 1042 regeredes af danske konger. Grundtvig karakteriserer i sin Indledning til Nordens Mythologi romerriget som en røverstat med en røverkultur (US V, 421-422).

18 Herkules] Grundtvigs betegnelse for England, som er "Herkules-Øen" (jf. senere i Nordens Mythologi, US V, 454; varieret på nordisk til “Asa-Thor paa Øen", 415). I Mands Minde-foredragene i 1838 betegnes England som "Herakles-Øen" eller "det store Thrudhjem" (dvs. Thors rige ifølge Resen 1665, fabel 19; MM, 443). I Nordens Mythologi kaldes Shakespeare "den ny Herakles" med den klassiskkyndige Ben Jonson som sin Cerberus (US V, 416) - det var jo et af Herakles' 12 arbejder eller prøvestykker at skulle kue Hades-hunden med de tre bidske hoveder og føre den bundet i en snor fra underverdenens port op på jorden (jf. udkast til Indledning, Thaning 1963, 132). Selv det i 1832 af Grundtvig så beundrede England har dog i kraft af den herskende romerkultur ved universiteterne i Oxford og Cambridge halvbygget sig "et underjordisk Herkulaneum til Jetten Hrungners Grav-Capel”, og det var til stor skade for den engelske litteraturs historie, der med Shakespeares ord er blevet "a pit of ink", med Grundtvigs en "Klak" (blækklat) i stedet for en skrift (US V, 415416 med note *; Much ado about nothing, akt IV.1, v. 141-143). Senere bruger Grundtvig udtrykket "Nordens Herkulaneum" (US V, 507, jf. Bang 1932, 89) mere positivt om sporene i det nutidige England af en oprindelig førkristen nordisk "Natur-Religion", forstået som det nordiske kæmpeliv, der ikke udspringer af "nogen anden Natur i Mytherne end Kampernes Egen" - det er en indirekte polemik imod den islandskfødte professor Finn Magnusens mytetolkninger i værket Eddaloren og dens Oprindelse, 1824-26, der går på "døde Ting og Krafter" (fx ånd = vind, Balders død = vinternat). I et udkast til Indledning til Nordens Mythologi (Fasc. 269.11) beskriver Grundtvig det antikke "Herculaneum" som et dødt sted, hvor livet smerteligt fattes og ikke kan fremkaldes (Thaning 1963, 116); den lavabegravede romerby ved Napolibugten blev genfundet 1709 og forsøgtes netop i 1828(-35) udgravet (jf. Oplysninger til digtet "Italien" i Krønike-Riim, 1829, og til digtet "Rom, Florens og Neapel" i 1842-udgaven af samme, Grundtvig 1875, 270, 140 og 145).

20 Brev paa Evighed] hentydning til Jesu ord om apostlen Peter, pavestolens grundlægger (Matt 16,19).

21 dermed] dvs. med guldhammeren (som er stærkere end stål).

22 Som] hvad.

23 ham i Nord] verslinjen er en varieret gentagelse af v. 1, så "ham" må være Nordens Aand (jf. v. 25), men kan dog samtidig ifølge v. 24 være Odin. Manuskripterne A og B staver begge "Ham" og lader i øvrigt denne verslinje være begyndelsen på et nyt afsnit (Fasc. 388.135-136).

24 Diis] gudinde, nemlig Frigg, Balders moder og Odins hustru, der begræd hans død (Resens Voluspa 1665, str. 33).

25 Aandens] manuskripterne A og B har begge her "Livets" (Fasc. 388.135-136). 
28 Fimbul-Vinternat] tre vintre uden somre imellem, der med snefog, stærk frost, storm og manglende solskin var tegn på Ragnaroks komme (Resen 1665, fabel 48, samt eddakvadet Vafprúðnismál, str. 44). Fra sin første bog Maskeradeballet i Dannemark 1808, 1808, og til Nordens Mythologi, 1832, anså Grundtvig, dog med forskellige årsagsangivelser, sin samtid for stedt $\mathrm{i}$ dybe og alvorlige åndelige kriser (om 1832 siger fx US V, 394: "nu, da Alt er af Lave"), også i England (jf. Grell 1992, 112-121). Det europæiske revolutionsår 1830 bekom ikke Grundtvig godt.

29 Rune-Maal] poetisk-profetisk tale $\mathrm{i}$ gådefuld form, som den talende undertiden ikke selv forstår. Grundtvigs brug af denne genre kan ledes tilbage til en skitse i tilegnelsesdigtet til Frederik VI i Roskilde-Saga, 1814, hvor han som digter rapporterer: "Syner jeg skued, og jeg maatte riste / Runer i Rosens den hellige Vang, / Og om Saameget, som aldrig jeg vidste, / Toned min Sang" (US II, 612). Videre grubler Grundtvig over runegåder i digtet "Et Blad af Jyllands Rimkrønike", 1816, hvor han i stroferne 183-187 søger at tyde og gendigte runetemaer fra det dunkle eddakvad Sigrdrifumál (US III, 230-232, jf. Toldberg 1950, 64 og 89-94).

29 for Een] som udelukkende fremsættes og forstås af én selv; alene på egne vegne.

30 alle Kæmpers Bauta-Steen] alle heltes gravmonument, her brugt om en person, der ved en mindetale konstaterer det afgjorte ophør af nordisk helteliv. Senere i Nordens Mythologi mener Grundtvig, at Rolf Krakes historiske død i Lejre, som af en skjald er formet over Ragnarokundergangen $i$ mytologien, er ensbetydende med guldalderens endelige afslutning. Rolf lagde nemlig navn til den yngste nordiske kenning for guld, og i hans dage fandt det store slag på den islagte Vänern-sø sted mellem den norske kong Ale og den svenske kong Adils, "hvormed Asernes egenlige Liv og de Poetiske Kiendinger slutte" (US V, 713 samt 729-731, 733, jf. Resen 1665, fabel 64). Ordet "Bauta-Steen" betyder i moderne sprog en høj og indskriftløs sten, men barokdigteren Jørgen Sorterup skriver om "Adelrune Skrift i Baute-steene" (Poetiske Smaa-Sager, I (det udkomne), 1714, 59), og lidt senere definerer Holberg "Baute-Steine" ud fra deres graveringer (Dannemarks Riges Historie, I, 1732, Petersen 1923, 92). Grundtvig og hans samtid kan også bruge betegnelsen om en mindesten med indskrift på (jf. monumentet på Odden kirkegård over Willemoes og hans mænd: "Her er jeg sat til en Bautasteen / At vidne (...)", US I, 756).“

31 Græs] af sammenhængen til og med v. 36 fremgår, at danskhed er til stede, men lettere skjult eller forringet i nutidens England (som ekko fra et bjerg og knurren i et fangetårn). Hvorledes en uventet græsvækst kan være et positivt tegn, er ikke ganske klart. Begtrup nævner i en note uden kildeangivelse vendingen "Græs gror paa den Vej, som ingen vandrer" (Begtrup 1907, 112), men den omvendte og negative version heraf rubriceres hos Peder Syv som ordsprog under begrebet "Hoor, Skjørlevnet. Løs-agtighed. Ukydskhed": "Der groer ikke Græs 
paa alfare veje" (dvs. skøgekærlighed er ufrugtbar) (Kjær 1983, 195). V. 31 har ifølge manuskript A (Fasc. 388.135) oprindelig begyndt med ordet "Vanddret", men det overstreges, hvorpå Grundtvig tager fat igen i en ny linje. I almindelighed angiver udtrykket "der gror græs over", at noget er blevet glemt, tilgivet, udslettet, men med mulighed for at blive genopdaget og genoptaget. Ifølge Snorre kunne guden Heimdal høre græsset gro (Resen 1665, fabel 25), så Grundtvig har måske haft en Heimdal-oplevelse af en i stilhed fortsat vækst på formodet gammelt dansk område.

31 Danmarks-Vei] Denmark Street i London er en lille gade, der løber mellem Charing Cross Road og St. Giles High Street, som Grundtvig kan have lagt mærke til, når han fra sin første London-adresse i 1829 (Norfolk Street tæt ved Themsen ved det nuværende Victoria Enbankment) begav sig til fods til British Library i Bloomsbury, en strækning på omkring $1 \frac{1}{4} \mathrm{~km}$ (jf. Grundtvig senere i Nordens Mythologi, US V, 502, note **, samt Bang 1932, 64 med citat af et Grundtvig-udkast, hvor alle Danmarks-stednavnene (v. 31, 33 og 35) nævnes).

32 ved Thoms] Denmark Street ligger ikke ved floden, men i sin følgende opregning af Danmarksminder i England nævner Grundtvig poetisk floderne Thæms, Ex (Exe) og Cæm (Cam) i stedet for byerne London, Exeter og Cambridge.

32 vented ei] omtalen af græs skal muligvis signalere en forbløffende idyl midt i storbyen. I et brev 18. august 1829 til sin hustru beretter Grundtvig om spadsereture i Regents-Garden, der navnet til trods snarere er "en stor Græsgang for Kiør og Faar, med et Par Træer i" (Grundtvig 1920, 60, jf. Grundtvig 1875, 272). Allerede 12. juni 1829 havde han skrevet hjem om "de romantisk landlige Situationer man træffer midt inde i London; thi deels er alle de saakaldte Squarer, som er tykt saaede omkring mig, et Slags Torve, med en heel Have paa, hvortil alle de Omboende har Adgang, og deels kan jeg ved at gaae et Par Gader langt komme paa et Sted, hvor jeg med den ny store Universitetsbygning i Baggrunden, omringet af en Square og en stor gammel Have og med en Allee som Frederiksbergs lige for mig, slet ikke begriber, at jeg staaer midt i London" (Grundtvig 1920, 21). Grundtvig noterede i øvrigt senere sin beundring for nogle velholdte fortove i London og de gode engelske veje i almindelighed (jf. Det Danske Fiir-Kløver, 1836, GSkv II, 32)

33 det Danske Bjerg] Grundtvigs originale note giver forklaringen (jf. Grundtvig senere i Nordens Mythologi, US V, 502, note ${ }^{* *}$ ). I et brev til C. Molbech den 25. juli 1830 meddeler Grundtvig, at han på sin vej til Exeter ikke fik set så meget som et glimt af Stone-Hange (Stonehenge), og fortsætter lidt senere sin turistbeskrivelse: "Mange Alderdoms-Levninger har man vel i Exeter vandalisk ødelagt, men en herlig Ruin af Rougemont Castle har dog en Gentleman frelst, og det er en egen Følelse herfra at skue ned i den brede, dybe Dal, hvor Saamange af vore Landsmænd fordum maatte bide i Græsset for Land-Vætten i Vest-Sex" (Schrøder 1888, 174). Dalen beskrives sammesteds som "den udmærket deilige amphiteatralske Egn". Land- 
vætten (dvs. en ånd, der forsvarer et bestemt landområde) er kong Alfred den Store (849-99). I sin Haandbog $i$ Verdens-Historien, II, 1836, er Grundtvig bevidst upræcis med hensyn til Alfreds talrige sammenstød med vikingerne, "da de Blod-Bad for vore Øine allesammen ligne hinanden som to Draaber Vand" og udgør et urede, som allerede historikeren William af Malmesbury i første halvdel af det 12. århundrede opgav at finde rundt i (US VII, 19). Rougemont Castle i Exeter er bygget af Vilhelm Erobreren (efter 1066) for at holde befolkningen i ro. Hvad der i historiske kilder omtales som New Castle i Exeter - eller nu Exeter Danes Castle - blev udgravet i 1993 og åbenbarede et ufuldført borganlæg, måske fra 1136. S. A. J. Bradley har venligst gjort udgiveren opmærksom på, at Grundtvig inden sine Englandsrejser via hjemlån fra Det Kongelige Bibliotek skaffede sig førstehåndskendskab til de nordiske vikingers historie $\mathrm{i}$ England, fx gennem James Ingrams The Saxon Chronicle with an English translation and notes, critical and explanatory: To which are added chronological, topographical and glossarial indices, a short Grammar of the Anglo-Saxon Language, a new map of England during the Heptarchy, plates of coins, \&c, London, 1823.

34 Gienlyds-Dværg] i nordisk folketro betegnedes ekko som dværgetale (islandsk "dvergmál; dvergmáli"); Grundtvig meddeler senere i Nordens Mythologi, at han ikke har fundet myter herom og kun kender ordet fra Björn Halldórssons Lexicon Islandico-Latino-Danicum, 1814, der ikke angiver nogen kilde (US V, 553-554).

$35 \mathrm{Com}$ ] floden Cam ved Cambridge (biflod til Ouse) betegnes af Grundtvig som "den her ubetydelige Flod" (Grundtvig 1920, 150).

36 Knurrer] brummer (i modsætning til ordene "kvad tilforn").

37 det Danske Taarn] Grundtvigs fodnote oplyser sammenhængen. I brev til hustruen Lise fra Trinity College i Cambridge den 19. juni 1831 skriver han: "den eneste Høi jeg har seet (opkastet, siger man, af de Danske) ved Slotsruinerne er indelukt med Fængselet, saa kun Fangerne komme til Foden og slet Ingen til Toppen deraf' (Grundtvig 1920, 150-151). I 1804 var fængslet Her Majesty's Prison and House of Correction blevet bygget på den gamle slotsgrund. Normannerne havde i 1068 opført en borg på Castle Hill i Cambridge by, hvor en høj, Castle Mound, stadig er bevaret. - Efter v. 36 har manuskript A tre overstregede linjer: "Men Skjalde-Tungen sig der i Mund / Kun har som Toner i Harpe-Bund / Hvor Gran ei findes af Hande-Lag" (Fasc. 388.135). "Gran" (dvs. mindste spor) forekommer også i v. 190. Stedet er et indirekte Shakespeare-citat (jf. note til Grundtvigs note til v. 47) og lyder direkte citeret (om en harpe) "put into his hands / That knows no touch to tune the harmony" (Richard II, I.3, v. 164-165).

37 slumrer i Alfreds Grav] Alfred den Store (849-99) kristnede fra sit kongerige Wessex de danske vikinger, foranledigede skrifter oversat til angelsaksisk sprog og regnedes "paa en Maade" for grundlæggeren af Oxford University (jf. Grundtvigs Haandbog $i$ Verdens-Historien, II, 1836, US VII, 20, samt digtet "Fuglesyn af Oxford", 1843, trykt i Danskeren II, PS VI, 465-468) - det sidste dog med urette. Alfred er 
rent fysisk begravet $\mathrm{i}$ en New Minster ved Winchester, senere kaldt Hyde Abbey og bevaret som ruin, skønt gravens placering er ukendt. På sin vej til Exeter i 1830 skimtede Grundtvig Salisburys domkirketårn, Englands højeste, midt om natten, men ikke Stonehenge (Schrøder 1888, 173), mens han intet noterer om Winchester (et navn, som vist ikke forekommer i forfatterskabet overhovedet). Det er vel den sproglige forståelse af og følgelige kærlighed til angelsaksisk poesi, der i England anno 1832 kan siges billedligt at slumre i Alfreds grav. Allerede ved sit første Englandsbesøg i 1829 kendte Grundtvig til og havde benyttet værker af adskillige samtidige eller næsten samtidige engelske angelsakserforskere, så hans fremstilling af sig selv som nutidig genopdager af det angelsaksiske (fx $M M, 456-463$ ) er en bekvem og harmløs fiktion til hjemmebrug. Tak til S. A. J. Bradley for påmindelse herom og for assistance til noterne til v. 33-37.

Dana] det danske sprog og dets muse, der ikke længere forstås i England.

39 Alve-Dronningen] Grundtvigs oversættelse af titlen på det ufuldførte allegoriske nationalepos The Faerie Qveene, 1590-96, af Edmund Spenser (ca. 1552-99). Denne digter nævnes af Grundtvig som den eneste ud over Shakespeare under dronning Elisabeth i Haandbog $i$ Verdens-Historien, III, 1843-56 (US VII, 621). Manuskript A har ikke ordet, men B indfører det, endda med en note: "The Fairy Queen" (Fasc. 388.136), som trykket ikke medtager. "Flve-Dronnningen" bliver for Grundtvig et symbol på den engelske nation. I Nordens Mythologi understreger han, at "Alferne (the Elfs) have holdt sig bedst i Engeland" (US V, 546). Et stambogsdigt af 26. juni 1830 til dr. John Bowring kalder England “Alfe-Dronning" (Grundtvig 1920, 103, trykt 1869, jf. $P S$ V, 497). I brev til Molbech af 6. juli 1830 fra London skriver Grundtvig om byen som "capital of the Fairy-Queen" (Schrøder 1888, 169) og betoner videre i digtet "London", indsat i 1842-udgaven af Krønike-Riim, at hovedstaden kan kaldes således "kun fordi der hersker en borgerlig Frihed, man i alle andre Hovedstæder fattes", og netop denne fe sætter "alle Menneske-Livets Kræfter i Bevægelse" og gør historisk betragtet "Mirakler alle Vegne", hvor øvrigheden vil, og hvor folket kan tåle den (Grundtvig 1875, 240, jf. 203). I et brev 16. august 1843 fra England til dronning Caroline Amalie kalder Grundtvig England for en "Elvedronning-Øe" (Danskeren 1891, 213) og gentager betegnelsen - stavet med "Æ-" - i digtkredsen Christenhedens Syvstjerne. Et Kirkeligt Sagakvad (Grundtvig 1860, 85). I brev til sin hustru Lise fra London 13. juli 1831 kan Grundtvig dog også bruge udtrykket "den Fe-Dronning" om Clara Bolton (som han traf en eneste gang i sommeren 1830) (Grundtvig 1920, 160, jf. PS VI, 507), og i 1844 husker han hende i det først i 1942 i helhed trykte digt "Smaa-Fruerne" som "AlveDronning, høitbegavet" ( $V U$ VIII, 226). Frugtbarhedsgudinden Idun med udødelighedsæblerne betegner Grundtvig i Nordens Mythologi som "Alf-Dronningen (the Fairy Queen)", hvis giftermål med digterguden Brage bliver et symbol på "det lykkelige Ægte-Skab 
mellem den historisk-poetiske Veltalenhed og den Dramatiske Poesie" (US V, 664). I Brage-Snak, 1844, kalder Grundtvig endelig mundtlig tale for en "Alve-Dronning" (US VIII, 503). Alle anvendte betydninger er positive.

39 daanet] udsagnsordet "daane" er dannet af perfektum participium af "dø", men får betydningen "falde i afmagt eller dvale; besvime". At Danmarks døde er "dog kun Daanede, som skal nu bradt opstaae", bliver Grundtvigs tese i hans fortale til Nyaars-Morgen, 1824 (US IV, 246). Både "slumrer" og "daanet" angiver i nærværende sammenhæng en dvaletilstand, der kan afløses af opvågnen.

40 Herre-Færd] heltekamp; ordet har flere forskellige betydninger, som Grundtvig har benyttet sig af. Efter sammenhængen er det vel asernes kampe imod jætterne, som Nordens Mythologi beskriver i detaljer, hans "Kvad" omhandler. Ordet er måske forvekslet med "hærfærd" for "krigstog" (islandsk "herferð"). - V. 39-40 mangler i manuskript A, men kommer ind i B (Fasc. 388.135-136).

41 hist] i England; dvs. ved brug af det engelske sprog.

42 i Harpe-Bund] dvs. dumpe toner uden resonans. Under det første Englandsophold i 1829 generede det i begyndelsen Grundtvig, at ingen i London kendte og værdsatte ham som digter, historiker og forfatter, ja der var ikke en gang nogen, som interesserede sig for hans person (jf. brevene i til Lise i sommeren 1829, Grundtvig 1920, fx 13, $18,20,31,34,36,39,52$, og et par stambogsvers fra 1830 , PS V, 495499). Et udkast fra 9. juni 1832 til Fortale til Nordens Mythologi sukker: "En i sit Hjem navnkundig Skribent kan vel føle sig forstemt ikke blot ved, som oftest, at finde sig aldeles ubekiendt paa Øen, men især ved den ubetydelige Vægt, Man der lægger paa literær Navnkundighed og boglig Virksomhed' (Thaning 1963, 287). Hvad hans angelsaksiske projekt angår, stod det ifølge et brev 9. oktober 1830 til P. Fenger først for ham som "en stor og sær Vildfarelse", indtil han blev slået af, "hvor mange uformodenlige Ting der maatte sammentræffe for at giøre disse Ting muelige", hvor utilbøjelig han var i begyndelsen, og hvor "underlig [dvs. vidunderligt] Omstændighederne have føiet sig" til at drive ham frem igen, når han gik i stå og lod hænderne synke ( $B G$ II, 183). En langt senere selvironisk skildring af manglende videnskabelig respons ved sit første besøg på British Museum i 1829 for at se angelsaksiske manuskripter har Grundtvig lagt i munden på englænderen Klearby i det store episk-dramatiske digt Dansk Ravne-Galder fra 1860 (først trykt i 1909, US X, 455).

kiender] mærker noget til.

43 Hande-Lag] håndelag, færdighed; kunst.

46 Er ikke længer] begge manuskripter har det svagere "Dertil er ikke" (Fasc. 388.135-136), der mangler tidsfaktoren.

47 Pogen] skoledrengen.

47 nemme] lære.

47 fodnote *] Richard II, I.3, v. 170-171: "I am too old to fawn upon a nurse, / Too far in years to be a pupil now." Ordene siges sidst $i$ en længere replik til Richard II af Mowbray, hertugen af Norfolk, da 
kongen har landsforvist ham på livstid. På Englandsrejsen 1829 købte Grundtvig Works of $W$. Shakespear. Carefully revised and corrected, I-VI, 1745 (Grundtvig 1920, 27 og 188, jf. Fortegnelse 1873, 153).

49 der] i England; dvs. på engelsk.

49 bold] kækt, måske fyldeord uden betydning (jf. folkeviserne).

50 Gjør kun paa Mur og Bom den Vold] angriber og skader den kun fysiske forsvarsværker uden at trænge igennem.

52 svare] betale; hele udtrykket betyder vel, at Grundtvigs engelsk ikke kan skaffe hans tale lovlig indgang hos englænderne (vendingen er brugt mere konkret senere i Nordens Mythologi, US V, 726).

52 Øre-Sund] ordspil på Øresund som farvand og ørets sund (hørelsen) som indgangsvej til et menneskes bevidsthed. Den historiske Øresundstold opkrævedes af Danmark i tidsrummet 1251-1857.

54 Her] i Norden.

54 Glaser-Lunde] se note til v. 12; stednavnet er medtaget for at understrege kontrasten $\mathrm{i}$, at man i Norden, hvor det gamle udødelighedsland lå, nu kun interesserer sig for døde og deres anliggender.

55 Dødning-Ridt over Gjallar-Bro] Gjallarbrú er navn på en guldskinnende bro over floden Gjöl i de mørke og dybe dale, der ligger på vejen til Helvede. Odins søn Hermod red på Odinshesten Sleipner over broen på sin færd til Hel for at få Balder udfriet af dødsriget; broen vogtedes af en jomfru Móðguðr, der fortalte Hermod, at broen dundrede mere under ham ene mand end under fem skarer af døde, der netop havde redet over den i går, og at han ikke havde en dødnings lød (Resen 1665, fabel 44, floden er også nævnt i eddakvadet Grímnismál, str. 28). Dette og de følgende træk til og med v. 66 forudser en dekadent fascination og dyrkelse af barbarisk gru i nutiden (jf. v. 69).

56 huger] behager. - Begge manuskripter har i stedet for v. 54-56 kun den mindre anskuelige linje: "Her alle Kæmper i Høien boe" (dvs. er døde og begravede, Fasc. 388.135-136). "Skjalde-Munde" i trykkets udvidelse forbereder v. 58: "Nordisk Røst" (hvor manuskript A i øvrigt har "Skjalde-Røst", Fasc. 388.135).

59 Uden] dvs. klangen af ægte nordisk ånd misforstås uvægerligt og opfattes som tegn på de i v. 60-66 nævnte mørke og dæmoniske gerninger, ja ligefrem som noget direkte ukristent.

59 hvidsker brat] de to ord synes lidt modstridende - "hvisken" kan begrundes med angst for de i v. 60-66 beskrevne hedenske excesser, "brat" kan være "omgående, hver gang". Ordet gentages i v. 64 i den mere vante betydning. Manuskript B har ikke "brat" med (Fasc. 388.136).

59 under Øe] egentlig folkeviseformel, der forbundet med et bevægelsesverbum angiver en retning, "af sted". Det kan gå på, at den i det følgende omtalte Hervor blandt andet optrådte på Samsø (se næste note). Manuskript A har linjen: "Uden Man tænker[: see hi] paa hver Øe", B renskriver således, men retter til "under Øe:" (Fasc. 388.135-136).

60 Hervor-Mø] Hervor, skjoldmø i Hervarar saga ok Heidreks, datter af bersærken Angantyr. Da han var dræbt og højlagt på Samsø, opsøgte hun hans høj, kaldte ham frem af graven og forlangte af ham hans 
tryllesværd Tyrfing (eller Tirfing), smedet i sin tid af to tilfangetagne dværge og i stand til at hugge i sten og jern, som var det i klæde. Gengangeren véd, at der knytter sig en forbandelse fra dværgene til sværdet, og må tvinges til at aflevere det. Sværdet kræver nemlig drab hver gang, det er draget, og vil udføre tre niddingsværker og udrydde hele Hervors æt. Hun tager derpå til gamle kong Gudmund på Glæsisvellir. - Grundtvig omtaler sagaen i Nordens Mythologi (US V, 492, 734, 750-756).

61 Kogler] fremkalder blændværk.

61 nyt Ustyr] fornyet kaos, uorden, klammeri, spektakel. Det gamle ustyr i Hervarar saga var Hervors fremgaldring af sin døde fader, bersærkerkampe og specielt sværdet Tirfings forbandelse. Begge manuskripter A og B har i stedet for v. 60-61 en følelsesmæssig gentagelse: "Hør til den vilde Hervor-Mø / Hør, hvor hun vækker til nyt Ustyr", B understreger navnet (Fasc. 388.135.136).

62 Hjorvard, Hrane og Angantyr] navne på tre af de tolv bersærker, som Orvar-Od og Hjalmar sloges med på Samsø i begyndelsen af Hervarar saga (jf. Grundtvigs oversættelse af sagaen som "Sværdet Tirfing. En Skemtesaga", skrevet 1809, trykt separat 1810, men indoptaget i Idunna. En Nytaarsgave for 1811, udgivet i december 1810, PS I, 453 og 466, benyttet igen i citat i Nordens Mythologi, US V, 752). Andre navne fra dette dusin bersærker meddeles i eddakvadet Hyndluljóð, str. 23-24.

63 gnistrer] ifølge Grundtvigs gendigtning er hele Hervors færd til hendes faders grav på Samsø omgivet af flammer og lysende luer fra gravhøje, selv hendes fodspor brænder, og sværdet Tirfings gyldne hjalte er omhvirvlet af luer (PS I, 465-472).

64 Kors] ved korset (en ed), sandelig; ih! (udtryk for skræk eller forundring).

64 Tyrfing] se note til v. 60.

64 dages] viser sig, dukker op.

65 Kommer og lugter det] verslinjen må være en betingelsessætning med omvendt ordstilling, dvs. Hvis det [dvs. sværdet] kommer og lugter kristenblod, kan en blodig kamp ikke forhindres - en reaktion, nutidsmennesker ("Man" i v. 59) kan tænkes at have over for det gammelnordiske.

65 christen Blod] forbandelsen knyttet til Tirfing udtrykker Grundtvig således i 1809: "Hver Gang det blottes, / Blod det maa have" (PS I, 451, men anderledes 495 i 1838; US V, 750 har "det blodtørstige Tirfing"). Lugten af kristenblod er et træk fra folkeeventyr og overtro tilsat af Grundtvig. Både i 1809- og 1838-versionen af sagaen skildrer han en kamp i hedenskaben mellem Odins ætmænd og jætternes afkom, mens kristendommen er unævnt. Udtrykket her danner således overgang til Grundtvigs moderne tolkning af begivenhederne.

66 raades (...) Bod] afhjælpes.

66 Vaanden] sorgen, smerten, nøden, ulykken. - Manuskript A har ikke blanklinje til markering af nyt afsnit efter v. 66, mens manuskript B følger trykket (Fasc. 388.135-136). 
68 Staal] rå styrke, jf. note til v. 8

69 Guld-Fæste] dvs. styring ved guddommelige kræfter (jf. guld-billederne v. 8-15).

$69 \mathrm{Hel}]$ dødsrigets herskerinde, datter af Loke og jættekvinden Angrbóða (ordet kan også være et stednavn for Helvede) (Resen 1665, fabel 2728).

70 Diser] gudinder.

71 Løve-Hoved] dvs. kunstnerisk pynt, svarende til våbendyret løve (identificeret med mod, kraft og åben kamp).

71 Klinge-Klodd] knap på sværdhæftet. Manuskript $\mathrm{B}$ og trykket er her ens, mens manuskript A i stedet for v. 71 har en overstreget linje: "Kiender ei meer Man Bjarkemaal" (Fasc. 388.136-135).

72 Egg og Od] sværdæg og sværdspids, udspecificering af "Staal" i v. 68.

73 Thrud-Vang] Pruðvangr er navnet på Thors rige (jf. Resen 1665, fabel 19), og da England for Grundtvig er hjemsted for Herakles = Asa-Thor med hammeren $=$ den nye maskinelle industri, må Thrud-Vang være identisk hermed. Grundtvig lærte sig at se Mjølner som urtype på senere britisk dampmaskineteknik (jf. $M M$, 443-447), men forfærdedes dog også noget over den (nordamerikanske) materialisme og pengeglæde, den medførte, fx da han i 1843 betragtede de 100.000 skorstene i Birmingham og de 100 kulmiler i Newcastle (Bang 1932, 130 og 132, Grundtvig 1891, 209).

74 Gny] larm. Er det modsat de stilfærdige og idylliske landegne, Grundtvig fandt i England uden for byerne?

74 Glommens Elv] Glomma, Norges længste elv, strækker sig ca. $600 \mathrm{~km}$ fra Røros til Oslo (jf. Roskilde-Riim, 1814, US II, 494-497). Står v. 7374 for, at man i England forholder sig tøvende til Norges naturgroede og kraftigt artikulerede nynationalisme? - Manuskript A har i stedet for v. 71-74 blot: "Giælder for Galder nu Bjarkemaal, / Blus over Bavn for Surtur-Baal!" (Fasc. 388.135). Ildjætten Surturs ankomst er et af Ragnarokssignalerne (Resen 1665, fabel 48). A har endvidere blanklinje til markering af nyt afsnit før v. 75, B og trykket har ikke afsnit her.

76 Bøge-Kæmper med Sang i Mund] vel: store og brede bøge med løv, der hvisler i vinden.

77 Klippe-Væggen med Rune-Stav] da v. $75-78$ beskæftiger sig med dansk natur, er det antagelig en hentydning til en formodet runeindskrift på klippegrund i Runamo (i det gammeldanske Blekinge) (jf. Begtrup 1907, 117). Den var Grundtvig bekendt fra fortalen til Saxos Gesta Danorum. På et opdrag fra Det Kongelige Danske Videnskabernes Selskab arbejdede hans mytologiske rival Finn Magnusen i perioden 1833-41 med at udlæse den (som et formodet hidtil ukendt kvad fra Harald Hildetands tid). I realiteten var Runamo et naturfænomen (forvitring) og ikke en menneskeskabt indskrift, hvad der blev alment anerkendt fra og med J. J. A. Worsaaes bog imod Magnusen, Runamo og Braavalleslaget. Et Bidrag til archcoologisk Kritik, 1844 (med et tillæg 1845) (jf. Kjems 2006). "Klippe-Væg" signalerer noget lodret, men Saxo beskriver tydeligt landskabet som en vej, der snor sig på 
flad klippegrund, og sådan ses det også på den illustration, Stephanius har lånt fra Ole Worm til gengivelse $\mathrm{i}$ sin Saxo-kommentar (Stephanius 1645, 21-22); Grundtvigs 1818-oversættelse er i denne henseende korrekt nok. Manuskript A er efter denne verslinje begyndt på en ny linje med et afbrudt og overstreget ord, der kun kan læses usikkert som "Gethl", "Guthl" (tøddelen over vokalen mangler) eller "Gothl", vel Gutland eller Gotland, en anden østlig del af det gammeldanske rige, hvis form med -th- Grundtvig kender, men åbenbart ikke vil benytte (jf. den gammeldanske form "Gulland" i hans Haandbog $i$ Verdens-Historien, III, 1843, US VII, 449, 458). Et af Grundtvigs tidlige historikerforbilleder, C. C. Lyschander, benytter i 1622 allehånde versioner uden tydelig skelnen: "Gether oc Gother", "Guther eller Gother", "Gulland", "Guldland", "Gullandsfarere", "Gullandske", "Guthlandiske", "Guthiland" (efter dommeren Guthi), "Gutlender", "Gotlender" (men ikke "Gothland"!) - "Gether" forbinder han blandt andet med Varberg i Halland (Lyschander 1622, 28-33, 41-49, jf. 52-53 om retmæssige titler og folkenavne). Det tyder på, at den østgammeldanske Runamo-identifikation er rimelig. Alternativt til Runamo kunne det dreje sig om bornholmske lokaliteter, Grundtvig har læst eller hørt om fra sin eneste ven i studietiden i København, P.N. Skougaard, der i 1804 udgav bogen Beskrivelse af Bornholm, I, som han blev censurdømt for (jf. Nielsen 1966, 13-16). I sin dagbog for 11. oktober 1804 noterede Grundtvig sig fra vennens værk en beskrivelse af den bornholmske klippevæg ved Ringebakkerne som mere end stejl (Albeck I 1979, 173-174, jf. II 1979, 138).

78 Hrone-Klinten med Bjovulfs Grav] Roneklint, $12 \mathrm{~m}$ høj skrænt ud til Østersøen øst for Præstø. Lokaliteten regnes af Grundtvig for det sted, hvor helten Beowulf blev højsat. Grundtvigs fordanskning Bjowulfs Drape, 1820, har "Hrone-Næs" (263, jf. Thorkelin 1815, 208, 232), i Grundtvigs register står "Hrone-Klint" (319). Senere i Nordens Mythologi vender Grundtvig tilbage til Beowulfs høj (US V, 740). I mindedigtet "Min Moder", 1822, gjorde Grundtvig forsigtigt denne heltegrav til et modstykke til hendes gravsted på Præstø kirkegård (US IV, 205).

79 Guld-Sædevang] se note til v. 14.

79 Bauta-Steengiærde] gærde af bautasten, indskriftsløse høje granitsten, der navnlig på Bornholm er anbragt tæt ved hinanden i grupper. Der er oldtidsminder omkring Gamla Uppsala, hvor Fyris-marken skal have ligget. Manuskripterne A og B deler begge ordet "Bautasteen-Giærde" (Fasc. 388.135-136).

81 Mjøsen] Mjøsa, Norges største indsø, $100 \mathrm{~km}$ lang, Østlandet.

82 Dovre] norsk højfjeldsområde nord for øvre Gudbrandsdal.

82 Guldbrands-Dal] Gudbrandsdalen er en ca. $200 \mathrm{~km}$ lang dal, der strækker sig fra Dovrefjeld til Lillehammer. Den forkerte navneform bruger Grundtvig allerede i de nydigtede afsnit til trykket af Roskilde-Riim, 1814 (US II, 496). Kilden til Grundtvigs viden om Norges geografi 
kan være Lars Hess Bing: Beskrivelse over Kongeriget Norge, Øerne Island, Fcerøerne, samt Grønland, 1796 (jf. Albeck 1953, 188).

82 Hølge] Holge eller Haloge, norsk konge i Hålogaland (Helgeland), den sydlige del af Nordland fylke i Nordnorge. Snorre anfører, at han var troldkyndig, og at hans gravhøj var gjort af guld, sølv, jord og sten og tjente som offersted (Resen 1665, fabel 65). Denne kostbare grav, der foranlediger Norges eneste kenning for guld, er for Grundtvig med de blandede materialer ensbetydende med de islandske sagaer ("det Islandske Saga-Bibliothek") og deres stærkt svingende kvalitet og har ikke andre sidestykker end Beowulfs på "Rone-Klint" (US V, 734735,740 ).

82 Seng for Hval] hjemsted for hvaler; kenningagtigt udtryk om havet, vel så de norske fjorde, parallelt med autentiske hav-kenninger som hvalfrón, hvaljörð, hvaltún (hvalens land, jord, område). - Efter v. 82 har manuskript A to overstregede linjer i træk: "Har I ei mægtet" og "Mægted med Hjemmets" (Fasc. 388.135).

83 Trylle-Navne] magisk virkningsfulde navne, navne, der fremtryller bestemte begivenheder og situationer.

85 Marken] Danmark (som Hengst og Hors forlod, se næste note).

85 Hengst og Hors] brødre, der ifølge Bedas kirkehistorie Historia ecclesiastica gentis anglorum (fra 731) skal have ledet den angelsaksiske erobring af England. Da navnene betyder "hingst" og "hoppe", kan det dreje sig om en nordeuropæisk variant af de antikke grækeres dioskurer, de krigeriske rytterbrødre Kastor og Pollux. Grundtvig har et detaljeret kapitel senere i Nordens Mythologi om de to, "denne indviklede, men høist tiltrækkende Sag" (US V, 721-726, citatet her er fra 725 , jf. 683 , note **). Da Hengest ikke forekommer i danske oldsagn, identificerer Grundtvig ham resolut med Odins hest Sleipner, der med sine 8 ben kunne trave over havet så godt som på land (723). Mens Hors dør barnløs efter landgangen, bliver Hengest stamfader til kong Æthelbert i Kent, den første angelsaksiske kristne konge, død 616. Hengest forekommer også i Beowulfskvadet (jf. Grundtvig 1820, 100-104). I Haandbog i Verdens-Historien, II, 1836, er Grundtvig som historiker skeptisk over for parret (US VII, 8-9), og i 1846 formidler han til skolebrug, at Hengst er navnet på en viking, men Hors er en kenning for skib (jf. angelsaksisk "mere-hengest" og islandsk "baru hestur", Resen 1665, kenningeregistret under "Skipa Kenningar"), hvorfor navneparret blot angiver et søtog med "hele Flaaden" (Grundtvig 1847, 257).

86 Sværmere] glødende tilhængere. I 1842 betoner Grundtvig ironisk, at det 18. århundrede bruger betegnelsen, der oprindeligt stammer fra biernes liv, for "al Livlighed i Aanden" (Grundtvig 1875, 278).

86 Klør og Pors] dvs. kortspil og stærkt øl (brygget på porse i stedet for humle).

87 Pære-Skuder] egentlig små skibe, der transporterer madvarer til hovedstaden, her vel nedsættende om små skibe modsat statelige krigsfartøjer. 
87 Flynder-Skind] anvendtes blandt andet til at klare kaffe med, vel udtryk for billig hverdagsvare. - V. 87-88 er ikke med i manuskript A (Fasc. 388.135).

89 Volse] Volse er ifølge Grundtvig det rette navn på Vølsungeslægtens stamfader (Nordens Mythologi, US V, 747), der også forekommer i Bjowulfskvadet (Grundtvig 1820, 81-83, 322, 324). Det komplicerede spørgsmål om gothernes udvandring fra Sverige og deres identitet med Vølsungerne vil Grundtvig lade ligge rent historisk, men anser ud fra sin egen poetiske samvittighed, at det kan handle om folkehistorie, ikke om enkelte heroiske personer ( $U S$ V, 746-747, jf. 490-492). Volse eller angelsaksisk Wælse må ikke forveksles med Völsi, navnet på en præserveret hestepenis, som en ramhedensk bondekone drev kult med i fortællingen Völsapáttr i Flateyarbók, til Olaf den Hellige standsede hende.

89 Gøthe-Skov] Götaland, dvs. Sverige.

90 Kulsvier] kulsviere havde ry for at være uvidende og naive mennesker, der kunne bringes til at tro på hvad som helst, de fik meddelt på en fast og bestemt måde, herfra stammer det nedsættende folkelige udtryk "Kulsvier-Tro", der blandt andet kan findes hos Grundtvig i et indlæg imod den Copernicanske astronomi i 1837 (Toldberg 1950, 61, 260).

90 kun] manuskripterne A og B har begge i v. 90: "Kulsvider grim" (Fasc. 388.135-136), med et fint bogstavrim på "grov".

90 Kulfust] mand med sorte, kullede fingre; nedsættende om en smed. Ordet, der ikke forekommer i Grundtvigs 1819-oversættelse af Saxo, er tilsat i Anders Sørensen Vedels Saxo-oversættelse, 1575, parallelt med "Askeblæser" (Liber VI,6,6, svarende til latinsk "ciniflo"), om den kælne og degenererede guldsmed, som den gammelnordiske helt Stærkodder bortjager med skam fra kong Ingjalds hof ved at hugge endeballerne af, da han forsøger flugt (Vedel 1575, CXXII).

91 Gruus (...) Græs og Snegl] Sverige er bekendt for dygtige geologer, botanikere og zoologer (Begtrup 1907, 118). De tre ord handler alle om naturfænomener i niveau med jordoverfladen og vidner således sammen med beskrivelsen $\mathrm{i}$ v. 92 af altid vågen mistænksomhed og intolerance om Grundtvigs lave vurdering af svensk væsen.

92 Argus-Øine] Argus var et græsk mytologisk uhyre med 100 øjne fordelt over hele kroppen, af hvilke halvdelen var vågne, mens de andre sov (Grundtvig 1875, 234, Oplysning fra 1842); symbol på årvågenhed. Senere i Nordens Mythologi giver billedet Grundtvig anledning til et hib til den politicensur, han var underlagt (US V, 414). - V. 91-92 savnes i manuskript A (Fasc. 388.135).

$94 R o l v]$ den norske stormand Gange-Rolf eller Rollo, som landsforvistes af Harald Hårfager for vikingeadfærd på Norges kyster og derpå vandt hertugdømme i Normandiet i 911 ved venskab med den svage franske konge Karl den Enfoldige, hvis datter han ægtede (jf. Snorres Heimskringla), endda døbt kristent til Robert. Grundtvig kalder ham "Rolv" i sin Haandbog i Verdens-Historien, II, 1836, US VII, 99-105) og accepterer tøvende hans norske afstamning, skønt Robert Waces ufuldførte rimkrønike om ham, Roman de Rou, $1160 \mathrm{ff}$., ud fra den 
normanniske historiker Dudo gør ham til søn af en oprørsk dansk stormand (Grundtvig 1875, 282, Anmærkning fra 1829). Grundtvigs digt "Normannerne" i Krønike-Riim, 1829 og 1842, behandler Rollo og hans tid (sammesteds, 110-113). Ifølge brev fra London 11. september 1829 til P. O. Brøndsted ejer Grundtvig udgaven af Waces tekst (BG II, 176).

94 Nisser] egentlig lokale navnløse skytsånder knyttet til en gård; gårdboer (jf. v. 156). I Resens $E d d a$-udgave, 1665, er ordet den vante oversættelse til dansk af de islandske ord for dværge og alfer. Grundtvig bruger i sin Snorre-oversættelse betegnelsen nissekonge om en lokal småkonge eller underkonge (det er vel egentlig næssekonge, islandsk "nes(ja)konungr", modsat stolkonge), jf. hans brug af udtrykket "Nisse-Konge" senere i Nordens Mythologi (US V, 727) samt i Haandbog i Verdens-Historien, II, 1836 (US VII, 62). I digtkredsen Nordens Myther, skrevet 1864, lader Grundtvig Roms Pantheon være bygget for "al Verdens Nisse-Guder" (PS IX, 144).

95 fra Top til Taa] fra nord til syd, dvs. over hele Norge. I Haandbog $i$ Verdens-Historien, II, 1836, lægger Grundtvig vægt på, at Norge på grund af sin geografi fra ældgammel tid har været delt i "ligesaa mange Smaa-Riger, som der var Dale" (US VII, 56).

95 Vente-Brev] brev, der garanterer adressaten et embede, når dette bliver ledigt.

95 Engelsk Bill] i England var der i netop 1832 på den liberale whigpolitiker Charles Greys initiativ blevet vedtaget en valglovsreform, the Reform Act, der fordoblede antallet af vælgere og favoriserede det industrielle Nordengland frem for det landbrugsdominerede Sydengland. Loven var til gavn for en ny borgerstand, mens arbejderne endnu ikke var med. Grundtvig opholdt sig i London, da Underhuset den 6. juli 1831 "med stor Stemme-Flerhed" vedtog loven (ifølge tilføjelse af 7. juli til brev af 26. juni 1831 til $\mathrm{F}$. W. Treschow, $B G$ II, 196).

96 Storthings-Drømme] med Eidsvoll-grundloven af 17. maj 1814 havde Norge fået sit eget parlament, men det varede til 1884, inden parlamentarisme blev indført som normal praksis, i øvrigt for første gang i et nordisk land. - V. 95-96 mangler i manuskript A (Fasc. 388.135).

97 vandred I ud] dvs. som Hengst og Hors (v. 85), Volse (v. 89) og Rolv (v. 93-94). Begge manuskripter har "de" for trykkets "I" (Fasc. 388.135-136).

99 Luft] hentydning til den københavnske islandskfødte professor Finn Magnusens naturvidenskabelige udlægninger af de nordiske myter i hans oversættelse Den celdre Edda, I-IV (med delindledninger og punktkommentarer til kvadene), 1821-23, og i monografien Eddaleeren og dens Oprindelse, I-IV, 1824-26 (jf. også v. 102 og 108). Magnusen, der især betjente sig af astronomi og meteorologi, anså med tilslutning til Friedrich David Gräters bog Nordische Blumen, Leipzig 1789, guderne og deres omgivelser for diverse former for luftfænomener (Magnusen. II 1824, fx 129, 267, 274, 280, 282), valkyrierne var "oprindeligen visse glimrende Meteorer eller Luftsyner, som Ildkugler, flammende Nordlys o.s.v." (Magnusen 1821, 
62); andre træk i myterne forklarede han som forskellige typer nedbør. Den lærde islænder var dog aldrig arrogant eller fantastisk i sin behandling af stoffet $\mathrm{og}$ følte sig over for Gräter og andre tyskere som "kun en Novitz i den eddiske Exegetik" (Magnusen II 1822, 8, note **). Grundtvig polemiserer uden navns nævnelse imod Magnusen en del steder senere i Nordens Mythologi, men omtaler ham næsten ikke direkte og da kun kort, køligt og skeptisk - særlig dadel får hans "forfærdelige Mythologiske Lexikon, der kun er os til Byrde" (US V, 472 og 493, note ${ }^{*}$ ), nemlig Prisca veterum Borealium Mythologice Lexicon i bind III af den arnamagnæanske tekstudgave Edda Scemundar hinns fróda, 1828. Heroverfor har Magnusen rundt omkring nogle venligt mente henvisninger til Grundtvigs 1808-mytologi og Danne-Virke. Videnskabshistoriske æresoprejsninger af Magnusen er ydet af N. Lukman i artiklen "Vore Eddaoversættelser" i Gads danske Magasin, 1944 (392-397), og Jens Peter Ægidius i Vølvens spådom på dansk. En litteratur- og åndshistorisk undersøgelse, 1978 (31-37). Forståelsen af de nordiske myter som forklædt eller umodnet naturvidenskab fortsættes i øvrigt hos Johs. V. Jensen i Den lange Rejse, 1-6, 1908-22 (samlet og let forkortet udgave 1-2, 1938), med efterskriften Astetik og Udvikling, 1923, samt i rejsebogen Nordvejen. Indtryk af norsk Natur, 1939, og hos Thøger Larsen i hans posthume roman Frejas Rok, 1928.

100 tydsk Fornuft] Grundtvig lagde hele livet afstand til den tyske oplysningsbevægelse, især i hvasse karakteristikker i Udsigt over Verdens-Krøniken fornemmelig $i$ det Lutherske Tidsrum, 1817, og forligte sig heller aldrig med oplysningsforfatteren Voltaire i Frankrig (jf. Kort Begreb af Verdens Krønike i Sammenhoeng, 1812, US II, 290 og 368, jf. 172, 291, 305, 321, 336, 338, 363, 368, 372; Grundtvig 1875,234 med negative portrætter fra 1829 og 1842). At Grundtvig i 1817 udnævnte Goethe til "den tydske, eller vel tydeligere den virkelige Voltaire" (US III, 715), er slemt ment, fordi Grundtvig finder, at tyskeren har "Magt til at sætte Glands paa, hvad han vil", mens franskmanden kun bygger på overfladiskhed og skin. Grundtvigs foragt for oplysningstiden kan blandt andet dateres tilbage til hans fætter Henrich Steffens' 8. indledningsforelæsning 1802 (Kondrup 1996, 139-142).

101 Friggas Graad] se note til v. 24.

102 hvad der fugter] manuskripterne A og B har det vagere og ikkeallittererende "hvad Man seer" (Fasc. 388.135-136).

102 Duggen] Grundtvig hævder senere i Nordens Mythologi, at naturforskere endnu ikke har kunnet forklare fænomenet dug, som han derfor udlægger som "et Billede paa det Vederkvægende, Poesien har for Menneske-Hjertet" (US V, 534).

103 Æventyr] fantastiske historier, løgne, opspind.

105 Knald og Fald] voldsomt og blodigt slag; kamp og undergang; hasarderet vovestykke.

106 Skin] ydre, men tom pragt. Grundtvig udlægger i 1842 ordet som "Udseende af noget stort, sandt eller skjønt, som fattes" og bruger det 
om den franske oplysning i det 18. århundrede, der indtog næsten hele Europa og endnu søger at jage sandt åndsliv på flugt til dødsriget som en anden Odysseus (Grundtvig 1875, 275). Manuskripterne A og B har her "Vind i Ærens Hald" (Fasc. 388, 135-136), hvor vind betyder blændværk, humbug, jf. ordet "vindmager" og Grundtvigs glose "Vind-Roser" (se note til v. 146).

107 Lykke-Spil] lotteri, hasard.

108 Gas] ordet går utvivlsomt på Finn Magnusens hårdnakket gentagne udlægninger af asalæren som luftfænomener, men denne synes dog aldrig at have benyttet det, skønt han nogle gange kommer ind på, hvad der må være gas-arter. Det ondes gennembrud i verden ved fimbulvinteren skyldes $\mathrm{fx}$ "Havets mod Himlen i usædvanlig Mængde opstigende (men til Snee forvandlede) Dunster" (kommentar til eddakvadet Hyndluljó d str. 40, Magnusen III 1822, 34). Desuden nævnes indernes "qvælende Dunsters og slige skadelige Naturphænomeners Dæmoner” (Magnusen II 1824, 23), “de fra Dybet opstigende Dunster" ved dværgenes fremstilling af Mjølner og de ligeledes damp-avlede "skinnende Luftsyner", der ligger bag forestillingen om Odinsspydet Gungner (Magnusen III 1825, 306); en indisk undergangsmyte siges at opvise "en giftig Vind, som dræber alle levende Væsener", ligesom Thor i Ragnarok kvæles af "Jordslangens eller det rasende Storhavs voldsomme Brænding og giftige Uddunstninger" (Magnusen IV, 1826, 512-513, 526, jf. Resen 1665, fabel 48: “Forgifft”). “Gas” får på dansk først omkring 1950 betydning af "løs snak, pjat, spøg”, så den nuance kan Grundtvig ikke sigte til. Kulgas anvendes ikke kommercielt i Danmark i 1832 (gadebelysning ved gas indførtes først i København i 1857), selv om Grundtvig åbenbart allerede i 1835 har hørt om noget sådant (jf. et da utrykt digt, $P S$ VI, 142). "Gas" må betyde ildelugtende og dræbende luftarter og være Grundtvigs sprogligt bevidste nedvurdering af Magnusens meteorologiske diagnoser. Magnusen var enig med Gräter (se note til v. 99) om, at verdenstræet var æteren eller et blot luftbillede (Magnusen II 1824, 129, jf. Magnusen 1821, 59), høgen på ørnen i træets top var "den stormdæmpende, vindstille Æther, der er ovenfor den lavere Luft" (Magnusen II 1824, 267), mens ørnen er "Skyeluften" (274), de fire navngivne hjorte er de fire hovedvinde, der kunne "forudsige vaadt eller klart Veirlig ved visse Tegn" (280) og desuden "tære og adsplitte Skyerne" (Magnusen 1821, 260). Magnusens konklusion er, at Ygdrasill udgør "et digterisk Sindbillede paa vor Verden; og at de i Mythen forekommende Dyr forestille Naturens vigtigste Phænomener”, beskrevet i en allegorisk og gådeagtig stil, som den kendes fra de gamle egyptere, indere, keltere og de ældste hellenere (Magnusen II 1824, 282). Heroverfor kan Grundtvig kun regne Magnusens tolkning af asken Ygdrasill for en ufrivillig "Spas", eftersom fx egernet Ratatosk hverken kan identificeres med hvid sne eller med grå tåge (US V, 524, samt Brage-Snak, 1844, US VIII, 539-540 og 544, Magnusen II 1824, 129-130). Grundtvig kan godt se asken som et symbol på "skjulte Natur-Virkninger", men 
finder, at hele beskrivelsen af den "henviser paa det historiske Menneske-Liv" (US V, 525). Grundtvig går ind for forfædrenes tænkemåde, som var "med den høieste Sikkerhed at slutte fra Virkningen til en forholdsmaessig Aarsag, og fra Kraften i Noget til Dets Egthed i sit Slags, en Grund-Sætning, der, udenfor Engeland, nu længe kun har været hyldet paa Papiret og fornægtet i Livet"; forkerte gætninger skal forkastes, når "de angive en Aarsag, der staaer i et øiensynligt Mis-Forhold til den sikkre Virkning, som derved giøres uforklarlig" ( $U S \mathrm{~V}, 522$ ). Lidt videre i teksten belærer Grundtvig, stadig uden navns nævnelse, Magnusen om hans hovedfejl som mytetolker: "Det ligger nemlig for det Første i Billed-Sprogets Natur, som selv de usleste Rim-Smede har en dunkel Følelse af, at Man ikke betegner det Synlige med noget Usynligt, eller det Narvarende med noget Fravarende, men netop omvendt, saa ikke selv den elendigste Smører, vil, naar han mener "Ild" sige "Kiærlighed" naar han mener "Vind" sige "Aand" naar han mener "Vand" sige "Flauhed", men netop omvendt, og selv fra den allerlaveste Stand-Punkt i Poesiens Verden, maa Man da korse sig over saadanne Forklaringer af OldTidens Billed-Sprog. Men for det Andet er det ligesaa vist, at naar enten Solens Opgang, eller Havets Brusen, eller nogen anden NaturBegivenhed skal kunne begeistre en Digter, da kan det umuelig skee ved det alene, der sees og høres, men maa være enten ved den umiddelbare Virkning deraf, eller ved en Tanke-Rokke som knytter sig dertil, saa, vil han yttre sig poetisk derom, vil han altid stræbe at udmale Scenen, og aldrig i et dødt og dunkelt Ord indslutte den store Hemmelighed, at somme Tider er det lyst og somme Tider mørkt, somme Tider sveder Man, og det er gierne om Sommeren, og somme Tider fryser Man, især om Vinteren, somme Tider bliver Man giennemblødt, sædvanlig naar det regner stærk, og til andre Tider har Man Sit paa det Tørre, især ved Mid-Sommer, naar Man slikker Soel-Skin" (US V, $524-525$ ). To originale fodnoter af Grundtvig om henholdsvis islandske skjaldes misbrug af billedsprog $\mathrm{i}$ deres kenninger og Shakespeares bevidst enfoldige definition af "a natural philosopher" brugt af fårehyrden Corin i As you like it, III.2, 1. 22-34, er her udeladt fra citatet. Senere i Brage-Snak, 1844, tilskriver Grundtvig dog "Dunsterne af det store Miød-Bryggeri under Ygdrasil" (dvs. Mimers brønd, US VIII, 547) virkning på Odin og på digtere, hvad der kan være "Gas" $i$ en anden mening end Magnusens nøgterne inddeling af luftlagene. - I manuskript A lyder v. 108 først: "Andet til Maal end hver Mand vil!" (Fasc. 388.135), men det overstreges og erstattes af den åbenbart velbetænkte "Gas - Ygdrasill"-linje; B svarer her til trykket (136).

109 vist] i usvækket betydning: med sikkerhed; fuldt og fast.

110 nok] ordet angiver en lidt skævt konstrueret modsætning til "Derfor".

110 altid breed] jf. Matt 7,13: den port er vid, og den vej er bred, som fører til fortabelsen, og de er mange, som går ind ad den.

111 Hunde-Forstand] på islandsk angiver ordet "hundvíss" en stor visdom (fx eddakvadet Hýmiskviða, str. 5), oftest tillagt jætter med nedsæt- 
tende klang, men forstavelsen "hund-" er en bestemmelse af størrelse eller omfang (hundrede; dvs. store; mange) og kommer ikke af ordet "hundr" (hund). I. v. 142 står "Hunde-Sjæle". Det store flertal af danske sammensætninger med "hund-" er negative. Manuskript A (Fasc. 388.135) har "Dyre-Forstand", men retter til "Hunde-", hvad der følges i B (136) og trykket.

111 Røver-Kiøb] meget billigt; spotpris.

113 Helte] nemlig i modsætning til "Skiftinger" i v. 116.

113 Hald] Valhal, Odins bolig, var hjemsted for faldne helte (Resen 1665, fabel 18).

114 Tog (...) paa Skjalde Tal] hentydning til Skáldatal, en liste på 60 skjalde fra Stærkodder i oldtiden op til ca. 1300, bevaret i to manuskripter af Snorres Edda (Upps. De la Gardie 11, AM $7614^{\circ}$ (afskrift af tabt original)).

116 Skiftinger] egentlig børn af overnaturlige væsener, der lægges i menneskers vugger i stedet for endnu udøbte menneskebørn; mere alment: vanskabninger, som i Grundtvigs generelle mytologiske perspektiv er forkastelige ved risikoen for at blande jætte- og menneskeblod.

116 Helas Favn] den latinske form for navnet på dødsrigets herskerinde, Lokes datter Hel (Resen 1665, fabel 28).

118 Grimners-Maalet] eddakvadet Grimnismál, str. 23, jf. 8-10, jf. Grundtvigs originale note * (jf. Resen 1665, fabel 35).

119 Portes Tal] se Grundtvigs originale note *.

120 Prim-Stav] egentlig stok med indskårne mærker, der tjener til almanak; runekalender; her mere alment om islandsk kildemateriale i prosaform.

120 ei er stjaalet] ikke stammer fra, jf. Grundtvigs notetekst *; det "høiere Tal", den nævner, bliver i alt 432.000 kæmper - tallet svarer til antallet af år i indisk kosmologis fire tidsaldre (mahayuga) (jf. Grundtvigs protestbemærkning, US V, 592, som kan sigte til præsentationen af regnestykket i Magnusen 1821, 249-250). Fra og med 1815 nærede Grundtvig stigende skepsis over for den fra omkring 1700 herskende forestillling hos danske historikere - betegnet som den islandske hypotese - om, at den islandske overlevering af nordiske myter, sagn og oldhistorie var meget ægtere og værdifuldere end den danske historieskrivning hos Sven Aggesen og Saxo (se Nordens Mythologi, US V, 497-501). Grundtvig argumenterede blandt andet med, at de danske kilder faktisk var ældre i overlevering end de islandske (jf. udkastet "Om Nordens Oldsagn", juni 1823-februar 1824, Fasc. 256, 2r-v); i et udkast ca. 1824 til en fortale til en ny udgave af den udsolgte Nordens Mytologi anklages mytologiens "senere Talsmænd" for enten som Oehlenschläger at lege med den eller at have "holdt sig til det Sandselige" (dvs. Magnusen?) (Fasc. $251,8 \mathrm{v}$ ).

121 Kæmpe-Viser fleest] den danske folkevisenedtegning er både den ældste og den omfangsrigeste i forhold til norsk, svensk, islandsk, engelsk og skotsk. Verdens første trykte samling af folkeviser, Anders Sørensen Vedels Hundredvisebog, udkom i 1591, men var oprindeligt 
bestilt som renskrift af Frederik II's dronning, Sophia (jf. fremstillingen senere i Nordens Mythologi af den særlige danske omsorg for viserne, US V, 464-465). I øvrigt anser Grundtvig den danske folkevisetradition for et kvindeligt anliggende (500 med note *, jf. BrageSnak, 1844, US VIII, 626) - dog, hvad håndskrifterne angår, ikke ganske med rette (Lundgreen-Nielsen 2002, 164-165). Grundtvig udgiver i 1847 en antologi af 72 folkeviser under titlen Danske Kampeviser til Skole-Brug, mens betegnelsen folkevise i moderne forstand først slår igennem efter Svend Grundtvigs store tekstkritiske udgave, Danmarks gamle Folkeviser, $1853 \mathrm{ff}$.

124 Valhalds-Fest] på taget af Valhal stod geden Heiðrún, hvis patter gav mjød hver dag i et kar så stort, at alle krigere kunne drikke efter behov (Resen 1665, fabel 35); der drikkes dog også øl, serveret af møer, som tog vare på fade og køkkentøj (fabel 31); middagsmaden udgøres af galten Særimner, hvis flæsk vokser ud igen om aftenen (fabel 33, jf. eddakvadet Grímnismál, str. 18). Odin selv spiste intet, men levede af vin alene (Resen 1665, fabel 34).

125 Opskærs-Gilde] høstgilde. Af fortsættelsen fremgår, at festen her er et billede på Valhals to daglige glæder: kampen til døden og en påfølgende opstandelse fejret med et yppigt måltid. Senere i Nordens Mythologi betragter Grundtvig livet i Valhal som et udtryk for "den Jordiske Udødelighed, der hos alle Folk med Aand og Hjerte, er et Ønske" (US V, 585, 594-595).

125 Agers Sal] havguden Ægir boede på Læsø (Resen 1665, fabel 50), men besøgte aserne og indbød dem til genvisit; de tog af sted uden Thor og måtte se lystig selskabelighed forstyrret af Lokes angreb på dem alle en for en, indtil Thor dukkede op og jog Loke bort (fabel 58, jf. eddakvadet Lokasenna).

126 indhøstet (...) paa Val] krigerne i Valhal sloges hver dag og dræbte hinanden for at genopstå til måltidstimen (Resen 1665, fabel 35).

127 Steen-Stuen] oprindelig et tårn eller hus bygget af sten som det sikreste tilholdssted på en middelalderlig herregård, der ellers var af træ eller bindingsværk; stenstuen havde skorsten og kunne opvarmes. Her vel snarere brugt om Valhal som en gennemsolid og urokkelig bygning.

127 Laurbær-Kost] laurbærgrene (og -kranse) var i antikken sejrstegn; her kan den uvante ordsammensætning gå på de altid lykkeligt gennemførte kampe i Valhals gård, før det fortjente måltid vankede. Den gammelnordiske tradition véd ikke af laurbær, og en kost af laurbærgrene er næppe noget praktisk redskab til hverken rengøring eller indvielse, selv om olien i bladene gav en fin aromatisk duft fra sig.

128 Idunnas Most] Idun eller på latin Iduna (Resen 1665, fabel 24, jf. 51-52) vogtede de æbler, som hindrede aserne $\mathrm{i}$ at ældes. Når Grundvig djærvt tilføjer, at hun gør most af dem, kan det være et lån fra Oehlenschlägers uhjemlede formulering i "Thors Reise til Jothunheim" fra Nordiske Digte, 1807 (Fjerde Sang, str. 29). I Frederik Barfods tidsskrift Brage og Idun, I, 1839, taler Grundtvig endnu mere hverdagsagtigt om “Æblegrød” og “Æblemoes" af hendes kostelige frugter (Barfod 1839, PS VI, 207). 
130 lode siden Vugger gaae] dvs. blev siden mødre.

132 Vinge-Vølund] Vølund smed i eddakvadet Völundarkviða ejede et par vinger, der skaffede ham hævn over kong Niduðr.

133 Age-Thor] henvisning til Thors kørsel med sine gedebukke for kærren (misforståelse af islandsk Ökupórr).

133 og 135: Der vist (...)] eftersætninger til v. 129: "Ja, hvor (...)".

136 Kæmpe-Sværd] heltesværd. - V. 129-136 mangler i manuskript A (Fasc. 388.135). Tilføjelsen af dem i manuskript B (136) og derefter i trykket sætter en menneskelig tidsdimension i kraft og indfører dels et slægtsperspektiv, dels en forvisning om børnenes individuelle udvikling.

137 Kæmpe- Æt] helteslægt.

140 Vidd] kundskaber, klogskab, sund sans.

140 Dyd] fortjenstfuld optræden; god moral.

141 Slaget] kampen; evt. mere præcist om et "Hammer-Slag" (v. 157). Manuskript A har oprindeligt "Kampen", men retter til "Slaget", som overgår til B (Fasc. 388.135).

142 Hunde-Sjæle] lave og usle personer (jf. v. 112). Manuskript A har "Dyre-Sjæle", B har som trykket, begge steder er uden rettelser (Fasc. 388.135).

142 Folke-Ham] menneskelig skikkelse, næppe folk $\mathrm{i}$ betydningen nation eller befolkning. Både manuskript A og B staver "-mm" (Fasc. 388.135-136), jf. v. 160.

143 gnave paa Askens Rod] slangen Niðhöggr bider i asken Ygdrasills rod (Resen 1665, fabel 14, jf. eddakvadet Grimnismál, str. 35; ifølge Resens Voluspa 1665, str. 37, en ligædende dæmon).

144 skylle Bleer] dvs. nedladende og foragtelig handling. Det skal måske forstås præcisere som en beskrivelse af barnagtige litterære fejder på vers (Begtrup 1907, 122), som der ikke var mangel på i dansk romantik under Frederik VI.

144 Kvasers Blod] Kvaser blev skabt ud fra en blanding af spyt fra aserne og vanerne og var en vismand, der vidste alting. Han blev dog dræbt af to dværge, som samlede hans blod op i to kar og en kedel. Blodet blandede de med honning og fremstillede dermed en digter- og vismandsmjød, som senere blev overtaget af jætten Suttung og til sidst efter mange anstrengelser kom i Odins eje (Resen 1665, fabel 60, 61 og 62). Udtrykket "Kvasers blod" er en kenning for poesi. Senere i Nordens Mythologi betegner Grundtvig denne myte som smagløs, men tager den dog alvorligt som poetik (US V, 757-759).

145 trampe paa Bifrøst-Bro] Bifrost er regnbuens bro, der fører til Valhal og bevogtes af asen Heimdal (Resen 1665, fabel 14 og 25, regnbue nævnes dog kun i dansk og latinsk version). I Ragnarok skal ildjætten Muspels sønner under ledelse af Surtur ride til Valhal ad broen, så den brister (fabel 4, 11 og 48, US V, 705), men Loke og hans sko er ikke nævnt her. Broens navn er i øvrigt afledt af verbet "bifast", at bæve eller bævre, og har intet med ordet "frost" at gøre (ordet deles "bifröst"), Grundtvig fordansker det til "Gynge-Broen" (US V, 671).

146 Grovt] manuskripterne A og B har begge: "Stolt" (Fasc. 388.135-136). 
146 Lap af Lokes Sko] Loke ejer i en myte om tilblivelsen af en række gudeklenodier "et Par urimelige Skoe, der skulde være saa gode som et Par Syvmiils-Støvler, baade til Vands og hen i Veiret", som han troede kunne sikre hans flugt fra et tabt væddemål, men Thor løb ham op og fangede ham (Nordens Mythologi, US V, 703, jf. Resen 1665, fabel 59). Hvem der har syet disse sko og givet Loke dem, berettes intetsteds. Men en anden myte fra Snorre kan være i spil i Grundtvigs verslinje. Den tavse as Vidar, søn af Odin, skal i Ragnarok træde undermunden ned på Fenris-ulven, der lige har slugt hans fader, og støde overmunden op mod himlen, så svælget flækkes, og det bliver ulvens død (Resen 1665, fabel 48). Vidar bærer på sin trampende fod en sko, som er gjort tyk og stærk af de trekanter, skomagere får til overs, når de har tilskåret skind til tæer og hæl; derfor hjælper mennesker, der smider disse lapper bort, med til Vidars faderhævn (Resen 1665, fabel 26, note (a) til den islandske tekst, og fabel 48, note (o) til den islandske tekst, indbygget i den latinske oversættelse, men ikke med i den danske; jf. Vries 1957, 276). Grundtvig mener snarere, at Vidar har båret en jernsko (Resen 1665, kenningeregistret under "Widar"), og kvier sig derfor ved skoen af læderlapper (US V, 706 , note $\left.{ }^{*}\right)$. Alligevel synes han uden belæg at antage, at en lap fra den ukendte fabrikation af Lokes tryllesko er gået til ildjætten Surtur, der med sine krigere skal få Bifrost til at falde sammen (stedet er ens $\mathrm{i}$ manuskript A og B og i trykket). Det er således en modmyte til Vidars hævn over ulven, resulterende i hjælp til jætternes ødelæggende fremfærd i Ragnarok. En parallel i det onde kan være Snorres beretning om (ild)jætternes transportskib Naglfar, gjort af negle fra døde mænd; hvis ikke de klippes af inden begravelsen, bistår man altså jætterne i Ragnarokskampen (Resen 1665, fabel 48, jf. Vries 1956, 285). Grundtvig synes så optaget af Lokes sko, at han ofrer en fodnote på at understrege, at de "svarer naturligviis til de Græske Sokker, saa de maae sagtens høre Comus og Momus til" (US V, 704, note $\left.{ }^{* *}\right)$. Soccus er en flad sko til antikke komedieopførelser, og tilhørsforholdet handler om komisk og satirisk dramatik (jf. US V, 470); Snorre-udgaven skriver på latin, at Vidar har den tykkeste sko, "Cothurnum habet spississimum" (Resen 1665, fabel 26), og koturner er i antikken sko med 15-20 cm høje såler til tragedieopførelser. Det er dog næppe rimeligt at udlægge Loke-omtalen i v. 145-146 som Holbergs spot over Nordens billedsprog (Begtrup 1907, 122), da Grundtvig senere i Nordens Mythologi forsoner sig med Holberg (US $\mathrm{V}, 469-470)$. Holberg interesserede sig ikke for nordisk hedenskab, som i hans trebinds Danmarkshistorie, 1732-35, kun får 103 sider af de i alt 2.480 dækkende tiden frem til 1660; om hedenske vers skriver han, at de "intet Poetisk havde uden Rimene" (Petersen 1923, 92). Efter v. 146 har manuskripterne A og B begge følgende vers: "Og med Vind-Roser paa femten Sprog / Broute, de vandt sig Thor til Maag", med en fodnote tilføjet i B: "See Alviis-Maal, hvor Dværgen vil have Thors Daatter." (Fasc. 388.135-136 - i PS V, 517, note 3, angiver Svend Grundtvig fejlagtigt, at B har "i" for "paa"). A har i øvrigt 
ingen notetekster, men et par asterisker som indvisningstegn. I eddakvadet Alvissmál vil en ordsnild dværg have Thors datter til ægte, men i en spørgerunde med Thor bliver han dog narret, for denne holder samtalen gående til efter solopgang, hvor dagslyset dræber dværgen. Dværgen udlægger en række naturfænomener på 6 forskellige sprog, så hvor Grundtvig har tallet "femten" fra, er ubekendt. Ordet "Vind-Roser" angiver vel tomme, men kønne betegnelser, sammensætningen er med den betydning uden belæg eller paralleller i dansk leksikografi. Alvissmál opviser nogle ord med "vind-", navnlig tillagt vanernes sprogbrug (str. 12, 18, 20, 22), men ingen vindroser. Kenningeregistret hos Snorre (Resen 1665) har heller ikke sammensætningen. Den frugtesløse ordrigdom kan være en spydighed imod Finn Magnusens eddaudgivelse med omkringliggende forskning, men kommer altså ikke med i trykket.

147 trumfe] spiller trumf ud, stikker (i kortspil), om overmodig og upassende opførsel. Der spilles selvsagt ikke kort i nogen nordiske myter, men Grundtvig har åbenbart fornøjelse af at anslå en stemning fra en borgerlig københavnsk klub, når jætternes nedbrydende virke skal skildres.

148 Hrungner-Kno] jætten Hrungner kom ved en fejltagelse til at ride ind $\mathrm{i}$ Valhal, drak sig fuld og begyndte at true aserne med død og undergang, hvad der førte til en vældig tvekamp, da Thor endelig kom til (Resen 1665, fabel 55).

149 Drikke] begge manuskripter A og B har her "Vædde", som i B rettes til "Drikke" (Fasc. 388.135-136). Hos Snorre er det Odin, der i en indledningssituation vil indgå væddemål med jætten (Resen 1665, fabel 55), men da denne uventet kommer til Asgård, bliver han hurtigt så beruset, at han truer alt og alle, så "Drikke" er mytologisk rigtigere. Desuden vil Grundtvig nok nødigt tilskrive jætter åndelige egenskaber, der sætter dem i stand til at overskue væddemål.

149 syv Boller Puns] både tallet og drikken punch er Grundtvigs gemytlige brodering på forlægget, der dels ikke specificerer kvanta, dels taler om $\varnothing l$.

150 her skal syntaktisk indtænkes et indledende "at".

151 Freya (...) Sif kun] Freja er van og kærlighedsgudinde, og Sif er Thors hustru. De pralende jætter er kun interesseret i disse gudinder, der står for henholdsvis vellyst og et godt udseende, men spotter alle guder (v. 155-156). Resens danske tekst har ved en trykfejl "Frey" (Resen 1665, fabel 55).

152 Gunst] yndest.

153 sidde paa Stads] sidde til pynt, paradere.

154 Vanehjems Diis] Freja.

155 nævnes] hos Snorre vil den berusede Hrungner ligefrem slå alle guder ihjel (Resen 1665, fabel 55).

156 Nisser] i Resens danske tekst 1665 bruges dette ord almindeligt, hvor islandsk har alfer eller dværge. Senere i Nordens Mythologi bruger Grundtvig fortrinsvis de islandske betegnelser (fx $U S \mathrm{~V}, 543-554)$. Her må "Nisser" være nedsættende ment (jf. v. 94). 
158 i Gaar] i fortiden, dvs. i de gamle myter.

159 Pande] Thor slog tit sine modstandere i panden med sin hammer. Det nærmeste islandske forlæg, Thors natlige slagsmål med jætten Skrym(n)er på rejsen til Udgårdsloke, har "Høffud" og på dansk og latin "Hofvedet" og "caput" (Resen 1665, fabel 38). Når Grundtvig specificerer til det fremhævede ord "Pande", kan det være for at få en bibetydning af "forstand; rationel fornuft" med.

159 Last og Skam] skade og beskæmmelse. Ordene indgår i fast udtryk for trussel eller forbandelse.

160 vor gode Hamm] vor venlige opførsel udadtil (?) (jf. sammensætning med "-Ham", v. 142). Det turde være for håndfast her at tale om "Poesiens Fjederham" (Begtrup 1907, 122), for "vor" er i konteksten de moderne menneskebørn af kæmpeæt; mytologisk ejes en fjederham af Freja og kan lånes af hende (US V, 550-551, 686, jf. dog også Vølunds vinger 553, 748-749). - Efter v. 160 har manuskript B et linjepar indført lodret i marginen med indvisningstegn: "Deres Fingre faae Smæk paa Smæk, / Som, hvor det giælder Gude-Sproget, / Smør os om Munden med Pen og Blæk, / Greb i Luften og Snak i Taaget;" (Fasc. 388.136). Både dette og det udeladte efter v. 146 (se note hertil) sigter vel til Finn Magnusens ekvilibristiske sprogkunnen som demonstreret $\mathrm{i}$ hans lærde, men atomistiske eddaforskning. Med historiografen Johannes Steenstrups ord var det hans metode ud fra sædvanligvis forkerte - etymologier at sammenligne religionsformer universelt ved hjælp af mytologiske enkeltheder. Magnusen var belæst og skarpsindig, men blottet for sund sans, så "det Simple og Ligefremme er ham altid mest imod" (jf. brev fra P. A. Munch til Jacob Grimm), og han nåede gerne frem til resultater, der uvilkårligt måtte slå omgivelserne som urigtige (Steenstrup 1889, 137).

161 deres Blod har ingen Nød] det er ikke nødvendigt at udgyde deres blod.

162 Smøre (...) os ei paa] ikke nyde, ikke gøre os til gode med; dvs. ikke være ude efter.

163 Risp] beget skomagertråd; hele verslinjen hentyder til en myte om kunstfærdige dværge, der efter et vundet væddemål om Lokes hoved måtte stille sig tilfreds med at sy hans mund sammen med en rem, fordi de ikke har vundet ret til at skære hans hals over (Resen 1665, fabel 59). Grundtvig udlægger senere i Nordens Mythologi dette træk som en pudsig, men ubehagelig og uhensigtsmæssig form for censur (US V, 704).

164 Hyl] manuskript B har til denne linje en fodnote: "Man husker nok Dværgen Brok og Loke." (Fasc. 388.136), som ikke trykkes.

166 Over dem age] denne og de følgende handlinger til og med v. 171 skildrer i transportverber den overlegenhed, som Nordens ånds børn føler at have over for jætter, antagelig med ordspil på udtrykkene "springe (..) over" og "seile der' egen Sø" (v. 167 og 169). Verslinjerne forbereder kappestridstemaet i v. 231

167 springe] jf. v. 5 med note. 
168 ride Sommer ad By] hente nyudsprunget majløv til byen som markering af sommerens begyndelse. Det er som tidskarakteristik modstykket til "Fimbul-Vinternat" (v. 28).

170 Drømme sig drukne af] bilder sig ind, at de har drukket sig berusede af. Hele verslinjen har måske svage klange af Johs. Ewalds "Til Sielen. En Ode", 1780, som Grundtvig op til og under julekrisen i 1810 kan have studeret (jf. Lundgreen-Nielsen 1980, 388-390). Det gælder fx Ewalds udtryk "drømmer Kræfter" (str. 4) og "Drukken af Mismod, kald nu din rasende / Stolthed, og kald hver svermerisk Drøm til Hielp!"' (str. 20) (Brix 1916, 259, 261).

170 Lethes] Lethe er glemselskilden i græsk mytologi, som en død skulle drikke af for at glemme sit jordelivs ubehageligheder (og for ifølge orfisk religion at berede sig på en senere genfødelse, jf. Vergils Eneide, 6. Sang, v. 713-715 og 749-751). Denne forestillling bringes på bane hos Magnusen som kommentar til eddakvadet Grímnismál str. 20 (Magnusen 1821, 245). I sin redegørelse for angelsaksernes historie i Haandbog $i$ Verdens-Historien, II, 1836, tager Grundtvig som fortæller afsked med dem ved at lade dem efter et dådfuldt liv "fængsles i de Dødes Rige og drikke af Lethe, saa de, fødte paa Ny som Engelsk-Moend, ei gienkiendte dem selv, og har de end lidt Skam deraf, er Skaden dog forvindelig, naar Man tænker, som Øboerne under begge Navne, at Liv og Frihed er ogsaa uden Stam-Tavler en herlig Sag" (US VII, 24).

170 Gammen] glæde. Udtrykket kan mere snævert forstås om de lærdes læsning af de døde romerske klassikere på latin (Begtrup 1907, 123).

171 ombord med Njord og Frø] hentydning til det magiske skib Skíðblaðnir, som dværgen Ivalds sønner havde smedet og siden forærede Frej; Njord er opdraget hos vanerne, men bor hos aserne som gidsel og ynder havet, søfart, fiskeri (Resen 1665, fabel 37, 59, 21). Senere i Nordens Mythologi behandler Grundtvig disse to maritime guddomme sammen (US V, 676-683).

172 Luv] vindsiden (som er fordelagtig for et skib med sejl).

173 Jotun-Kraft] jættekraft.

174 Grissel] stang med træplade for enden til at sætte brød til hævning i ovnen med.

174 Koste-Skaft] traditionelt heksebefordringsmiddel (jf. v. 177).

175 Kaal-Stok] madaffald.

175 Hør og Hamp] billige hverdagsvarer, som sælges af en hørkræmmer; måske billedligt om sejl og reb (?). Hampereb benyttedes til hængning af dømte. Alle tre betegnelser i verslinjen markerer noget usselt, værdiløst og foragteligt. Begtrup mener, at det går på "de døde Bogstaver" modsat det levende ord (Begtrup 1907, 123).

176 rene Former og Gas og Damp] disse ord kan betyde "æsthetiske Formler og naturvidenskabelige Theorier" (Begtrup 1907, 123). "Gas", jf. note til v. 108.

177 Bloks-Bjerg] bjerget Brocken i Harzen regnedes for det sted, hvor hekse kom sammen Valborgsaften, natten før 1. maj (jf. "Walpurgisnacht" i Goethes Faust, I, 1808, hvor hekse rider på høtyve, kosteskafter og 
stokke i damp, tåge, tågeslør og dis, en klud er nok til sejl og ethvert trug godt til skib).

177 Troms] fjeldet Trommen på Hvaløen (= Blåmannen på $1.050 \mathrm{~m}$ på Kvaløy) ved byen Tromsø (nær Finmarken), som efter norsk folketro var mødested for landets hekse Sankt Hansaften. Grundtvig genbruger udtrykket i 1834 i et da utrykt manuskript til en afhandling om statsmæssig oplysning (Bugge 1983, 24).

178 Thrym] jætte, der stjal Thors hammer (eddakvadet Prymskviða).

179 thinglyse] officielt bekendtgøre.

180 en vanskabt Knold] frit referat af Udgårdslokes (og ikke Thryms!) bemærkning, da Thor besøgte ham sammen med Tjalf, Roskva og Loke og tilsyneladende ikke trods al sin asakraft gjorde noget skræmmende indtryk på de kolossale jætter ved sin fysiske fremtræden (Resen 1665, fabel 39, jf. Grundtvigs genfortælling senere i Nordens Mythologi, US V, 644: "den halvvoxne Knøs"). At udtrykket skulle være Grundtvigs karakteristik af sig selv som bondeknold (Begtrup 1907, 124), er ikke sandsynligt.

182 Mjølner] Thors berømte kortskaftede hammer, der altid vendte tilbage til ham, når den blev kastet.

183 primer] taler i vildelse, vrøvler. Manuskript A og B har her "sværmer" (Fasc. 388.135-136), jf. v. 86.

184 otte Ben] Loke omskabt til hoppe bliver moder til Sleipner, Odins 8benede hest (Resen 1665, fabel 36). Senere i Nordens Mythologi udlægger Grundtvig de unaturlige 8 ben som "Aandens Ganger, altsaa, poetisk talt, Verset, der sagtens fra først af i Norden var et Slags Octo-Meter", jf. Völuspás 8-linjede strofer og det almindelige 8leddede islandske vers $(U S \mathrm{~V}, 601)$. Manuskript A har en æstetisk vinkel i en overstreget linje: "Styg er hans Hest med de otte Been" (Fasc. 388.135). - Efter v. 186 findes i manuskripterne A og B linjeparret: "Skam deraf, at med andre Øg / Sleipner farer, alt som han fløi!" (Fasc. 388.135-136), der ikke trykkes.

187 Ælve-Sal] Frej satte sig uden tilladelse i Odins tronstol Hlidskjálf og så derfra jættepigen Gerd, som han forelskede sig uhjælpeligt i (Resen 1665, fabel 32, jf. eddakvadet Skírnismál).

188 en Maanskins-Ka'l] en kærlighedens sværmer, drømmer; udsagnet her og i næste vers er en forgrovet version af, hvad Loke beskylder Frej for i eddakvadet Lokasenna (str. 42). Manuskript B staver mere korrekt "-Karl” (Fasc. 388.135).

189 Kiøbte sig Kys for Guld og Sværd] Frejs tjenestedreng Skirner tilvejebragte Frejs forening med Gerd ved at afgive hans sværd, som han derefter måtte savne i Ragnarok. Manuskripterne A og B (Fasc. 388, 135-136) har intet om guld: "Solgde for Mø sit gode Sværd" (jf. Resen 1665, fabel 32), mens eddakvadet Skirnismál har et tilbud om guldæbler og Odins armring Drypner (str. 19 og 21), og eddakvadet Lokasenna (str. 42) regner denne handel for gennemført.

190 Gran] støvkorn; meget lidt.

191 Ælve-Kongen] i myten om gudernes klenodier er det Loke, der giver Frej et af dværgesønner smedet skib, Skíðblaðnir (Resen 1665, fabel 
59, eddakvadet Grimnismál, str. 43). Hvis “Ælve-Sal” er Hliðskjálf, må dets konge være Odin. Men "Flve-Kongen" er nok snarere Ivald, faderen til de skibsbyggende dværge (jf. US V, 545).

192 Ælve-Piger] det er uklart, hvad Grundtvig hentyder til, men senere i Nordens Mythologi mener han, at Frej som kærlighedshelt skal have været særlig yndet af netop de danske kvinder (jf. US V, 678). Manuskript A har en ældre form: "Ælve-Piger af Graad et Hav", som overstreges og erstattes af en formulering svarende til trykket, dog uden fremhævelse (Fasc. 388.135).

193 Stout] stolt, prangende (på en hovmodig måde).

194 Bestik] bestemmelse af et skibs beliggenhed.

196 Lykkens] dvs. på lykke og fromme; tilfældigt (uden egen vilje og styrekunst). Denne nedsættende vurdering fra jætternes side af asernes trylleskib er der dog ikke hjemmel for hos Snorre (Resen 1665, fabel 37).

196 Dægge-Lam] lam, som opflaskes (af piger) uden at die moderen.

200 vor Fordeel] dvs. hvad der er til størst gavn for os (jf. Grundtvigs brug af ordet "Fordeel" senere i Nordens Mythologi, US V, 452). Manuskripterne A og B har begge i stedet for de to ord: "hinanden" (Fasc. 388.135-136). Efter v. 200 har manuskript A den overstregede vage linje: "Frihed er hvad vi Alle vil" (Fasc. 388.135).

201 Slagne] fremstillet.

201 Læst] træform i skomagerhåndværket; herefter: mønster, type, forbillede; dvs. være gjort på en vis måde.

204 Ødeland] normalt betyder ordet "person, der ødsler sine værdier væk; flottenheimer”. I rimbrevets kontekst skal ordet være parallel til destruktive naturkræfter og kunne så betyde "ødemark, goldt og ufremkommeligt land". Men ordet svarer til islandsk "landeyða”, der ifølge Snorres Heimskringla og Grundtvigs Anmærkning i 1829 til digtet "Harald Haardraade" i Krønike-Riim, 1829 og 1842, er navnet på denne norske konges krigsbanner, med betydningen ødelæggeren (Grundtvig 1875, 107 og 285), altså en metafor for krig. Opremsningen af nedbrydende og tilintetgørende kræfter kan minde om beskrivelsen af de fire ryttere i Åb 6,3-4 og (især) 7-8. I Kort Begreb af Verdens Krønike $i$ Sammenhong, 1812, bruger Grundtvig sammenligninger og billeder fra den uorganiske natur til sine skildringer af verdenshistoriske personer og begivenheder, som han lægger afstand til ud fra sin daværende bibelkristne målestok, mens positivt opfattede aktører karakteriseres med elementer fra organisk natur (LundgreenNielsen 1980, 559-561).

205 Ulv og Bjørn] (nordiske) rovdyr. I forbindelse med en redegørelse senere i Nordens Mythologi for, at nordisk helteliv udspringer af og bedst trives på havet (US V, 449-452 og 458-461), modsat det landlige hyrdeliv i Palæstina og (by)borgerlivet i Grækenland, hævder Grundtvig, at krig til lands er altid mere blodig end søkrig: "Hvor nemlig Land-Kæmpen ikke hæver sig som Røver og Mand-Draber, udmærker han sig som en Skytte, i Lag med Bjørne, Ulve og Ræve, som han staaer immer Fare for at lære af og efterligne" (452). 
208 Rimer] passer.

208 Øine-Forblindelsens Land] Jorden, menneskets verden; udtrykket kan gå på Platons klassiske idélære med skelnen mellem de usynlige idéer eller idealer og de synlige materielle fænomener (jf. v. 212: " tilsyne", v. 224: "synlige Ting"), mest tydeligt udtrykt i hulelignelsen i Staten (5. bog; jf. Grundtvigs digt "De Levendes Land", str. 5, skrevet 1824, men først trykt i 1832 i ændret form i L.C. Hagens samling Historiske Psalmer og Riim til Børne-Lardom, den ældste version tryktes i 1883 ved Svend Grundtvig i PS V, 283-286). Udtrykket kan samtidig hentyde til det islandske ord "Gylfaginning" (Gylfes synsforblændelse), der er navnet på den mytologiske hovedpart i Snorres Edda (opkaldt efter den dialogiske rammefortælling med kong Gylfe). Resens udgave oversætter det til dansk "Gylvis Beskuffelse" og latinsk "Gylvi illusio" (Resen 1665, fabel 1). På sin rejse til Udgårdsloke blev også Thor udsat for "Oine-Forblindelse" (US V, 647, jf. Resen 1665, fabel 41, på islandsk "Siónhuerffingar", på dansk "Kogleri"). I sin Groesk og Nordisk Mythologi for Ungdommen skriver Grundtvig ved Ødipus' gådegætning, at “Bloendvoerk er en Pestilens, men falder bort af sig selv, saasnart dets Hemmelighed, som er Tomhed, opdages" (Grundtvig 1847, 108). Heroverfor står så "den usynlige, men dog ganske virkelige Verden, som Ordet, at sige det levende Ord, der løber ud i Eet med Aand, baade skaber og befolker" (US V, 436). I øvrigt havde allerede Oehlenschläger i "Aladdin eller Den forunderlige Lampe" (Poetiske Skrifter, II, 1805) indlagt en romantisk-filosofisk monolog over "Blindvark" ved sultan Solimans Nar (den udelodes dog fra og med 2. udgaven i 1820).

209 Stif-Moder] stedmoder (ordet er grundled i sætningen).

209 Ulv og Bjørn] jf. v. 205 (ordene er genstandsled i sætningen). "Ulv" er nok i sammenhængen varulv (jf. gentagelsen af udtrykket i $1834 \mathrm{i}$ et da utrykt manuskript til en afhandling om statsmæssig oplysning, hvor Grundtvig præciserer til "Varulve" (Bugge 1983, 30)).

210 Skaber (...) af umyndige] henvisning til danske trylleviser om børn og unge, der af en ond stedmoder omskabes til vilde dyr (fx Danmarks gamle Folkeviser, II, 1856, nr. 55. "Jomfruen i Ulveham" (dvs. varulveskikkelse), nr. 64. "Dalby-Bjørn”). Manuskript A begynder verslinjen med ordet "Giør", der rettes til "Skaber", hvad der føres over i B og trykket. A har i øvrigt "uskyldige” (Fasc. 388.135), som også indgår i B, men overstreges, hvorpå "umyndige" tilføjes over linjen (136).

211 af Dyr har mest] senere i Nordens Mythologi i redegørelsen for den aldrig tilfrosne grænseflod Ifing, der skiller jætter og rimtursers rige fra gudernes, finder Grundtvig, at der principielt altid står en stor strid mellem "Guddoms-Gnisten i os" og "det dyriske, selvraadige Element" (US V, 540). I 1842 definerer Grundtvig det dyriske som hjemmehørende $\mathrm{i}$ den art mennesker, der "bryde sig, ligesom de umælende, kun om det synlige og haandgribelige" (Grundtvig 1875, 239). Ifing tolkes i øvrigt typisk hos Magnusen som "en mythisk Flod, 
formodentlig Luften eller Luftstrømmen, som adskiller Guderne fra Jætter og Mennesker" (Magnusen 1823, 249).

212 tilsyne som Folk er flest] med et bedragerisk udseende af at være ganske almindelige mennesker, altså en påmindelse om materiens upålidelighed.

216 har det godt $]$ vel: klarer sig fint uden at skade nogen og er tilfredse med deres liv, næppe udtryk for materielt vellevned, som Grundtvig aldrig forstod eller gik ind for. Den beskrevne misundelse vidner om den form for egoisme, Grundtvig senere i digtet "Folkeligheden", 1848, str. 7, placerer hos mennesketypen "Dragedukker" (profitmagere, spekulanter, som mangler sans for deres folk, deres modersmål og deres fædreland, jf. Lundgreen-Nielsen 1992, 32-33) (Danskeren II, US IX, 140).

217 Og] i manuskript B står der her "Som", men det overstreges og erstattes af "Og" (Fasc. 388.136), antagelig fordi Grundtvig indser, at to gange anaforisk anbragte "Som" i træk af læserne vil blive opfattet som henvisende til det samme, nemlig "alle" i v. 216. Rettelsen er sammen med slutkommaet i B's linje svarende til trykkets v. 216 et signal om, at subjektet for "broute af" (se næste note) er "Endeel" (v. 211) (anderledes Begtrup 1907, 126: de, der har "gode Kaar (...) vækker Vrede hos den usle Hob ved deres aandelige Fortrin", hvad han sammenligner med pariserpøbelens opførsel under Marat). V. 215-218 med de tre specifikationer af den dårlige frihed (v. 213) mangler $\mathrm{i}$ manuskript A (Fasc. 388.135) og kommer ind i B (136).

217 broute af] prale med; være stolte eller overmodige af. Ordet er på dansk entydigt negativt (jf. note her til v. 146) og kan næppe være brugt om de mennesker i gode kår, der nævnes i v. 216. - Efter v. 214 fortsætter manuskripterne $\mathrm{A}$ og $\mathrm{B}$ med så afvigende slutninger, at de mest hensigtsmæssigt beskrives for sig (se Tillæg her efter noten til v. 258).

219 Løsen] kampsignal, felttegn, feltråb; parole, nøgleord, motto.

220 Thor] Thor var den fornemste og stærkeste blandt aserne, men befinder sig med sin fysik og sit mod på et andet niveau end Loke, så det er to helt forskellige handlende figurer, Grundtvig knytter sammen i linjens senere så berømte formulering.

221 Ordet $]$ sproget (tale og skrift), der har fremkaldt moderne åndskultur, nemlig de i v. 223 og 229 opregnede områder (jf. fx Rønning 1912, 112). En anden mulighed er at læse "Ordet" som identisk med (nordvesteuropæisk) kristendomsforkyndelse (Christensen 1987, 210-211, Christensen 1998, 258).

221 Verdenen ny] den moderne (ånds)verden (jf. de hos Grundtvig hyppige nytårsbilleder og -sammenligninger samt den historiske betegnelse "Nyaars-Tiden" for epoken 1450 ff. i en Oplysning fra 1842 (Grundtvig 1875, 265) og generelt i Haandbog $i$ Verdens-Historien, III, 1843-56).

222 under Sky] egentlig: under åben himmel, i fri luft, billedligt: her på Jorden, i det verdslige liv.

223 Vidskabens] videnskabeligheds, måske bredere: viden om menneskelivet. 
224 Ligest] som mest ligner (jf. v. 232).

224 synlige Ting] ting, der tilhører sansernes fænomenverden (jf. noter til v. $208,211,212,235$ og 254).

224 Strand] dvs. modsat v. 223: " Land" og forberedende v. 229: "Hav" (jf. senere i Nordens Mythologi Grundtvigs overvejelser over forskellen på land- og havbaserede folks kultur, se note til v. 205). Strand- og landskabsbillederne v. 232-236 er således alle Grundtvigs poetiske omskrivninger af det altid bevægelige hav.

225 Blæst (...) Bjerg-Toppen hvid] et lignende, men mindre anskueligt billede af åndsliv som et landskab har Grundtvig i 1807 leveret i afhandlingen "Om Religion og Liturgie" (US I, 138-139): en dal omringet af et uoverskueligt "bølgende" Hav, som mennesket kun kan komme ud over til det ukendte land med renere luft, hvorfra det stammer, på to måder, nemlig enten ved poesiens vingede flugt eller ved filosofiens omhyggeligt byggede skib. Ingen af dem byder på varige løsninger, og mennesket tvinges derfor til at blive i dalen og nøjes med at finde regler for den bugtede vej, der fører til havet. I 1807 skildres hindringerne for menneskelig erkendelse i billeder af opslugende skyhøjt rullende bølger og stormende vinde, der gør mennesket til en passiv og begrænset størrelse, men i 1832 er kamp, bevægelse $\mathrm{i}$ naturen af bølger og vinde, modstand og drillerier tværtimod menneskets betingelser for aktivt at erobre og vedligeholde et åndsliv.

227 naar Kraften sig hyller i Damp] Begtrup gengiver dette poetisk meget frit som "hvor det bruser med Klang om Damperens Bov" (Begtrup 1907, 126). Denne maritime udlægning er uden dækning i verslinjen. Baggrunden kan være, at Grundtvig under Englandsrejserne stiftede bekendtskab med dampdreven trafik. En udflugt ad Themsen til Richmond Park 30. august 1829 var hans første tur på en dampbåd (Albeck I 1979, 433), i halvdårligt selskab, "da det slet ikke er Moden at betjene sig af Dampen til denne Lystfart, som honette Folk enten giør til Vogns, eller i deres Baade, med egne stadselige Roerkarle" (Grundtvig 1920, 67). Hjemrejsen fra England 12. september 1829 (til Hamburg 14. september og fra Kiel 17. september) med ankomst i København 18. september afvikledes ligeledes med dampskibe (Albeck I 1979, 433-434).

231 kappes] Grundtvigs begreb om det positive i konkurrence og kamp stammer fra den engelske liberalisme, som han navnlig stiftede bekendtskab med i teori og praksis under de tre sommerrejser til England 1829-31 (jf. Baagø 1955, 7-37, dog modereret Thaning 1963, 385 , note 12 vedrørende 375 , og Grell 1992, 11, 165, note 10 vedrørende 157-158). I digtet "Olympens Guder" fra Krønike-Riim til Levende Skolebrug, 1842, understreges de græske guders væsen: "Alle Livets ædle Kræfter / Mødes her med Kappelyst" og "Vædde-Kamp af alle Kræfter" (v. 5-6 og 17, Grundtvig 1875, 27-28).

231 om Rang], dvs. om førstepladsen. Jf. "Kirke-Klokken", 1845, str. 3: "Toner dine kappedes om Rangen". Efter denne verslinje har manuskript A har en dristigere, men overstreget linje, der mere selvfølgeligt 
gør åndslivets "Hav" (v. 299) til et landsceneri: "Bugner og blomstrer, og [ton] bølger i Sang" (Fasc. 388.135).

232 Ligner] manuskript A har i stedet ordet "Vorder", som lader en forvandling fra "Hav" (v. 229) til "Vang" (v. 232) finde sted, B har "Ligner" ligesom trykket (Fasc. 388.135-136). Rettelsen er ikke registreret af Svend Grundtvig (PS V, 520).

233 Borge og skyhøie Bjerge] disse romantiske landskabsingredienser skal afbilde havets bølgegang, men får nærmest digterisk egenværdi. Borge er sikre tilholds- og opbevaringssteder, og bjergene er tættest på himlen og udfordrende ved deres højde. I England $i$ august 1830 havde Grundtvig for første gang i sit liv oplevet bjerge (jf. Grundtvig 1920, 117: "Klippe-Egnen, som er mig noget Nyt", 121: "KalksteensKlipper, som paa den ene Side er skovbegroede", 122: "Bjergene i Wales"). Bjergoplevelserne under Englandsopholdet 1843 (jf. Fabricius 1952, 56) var således ikke hans første (som hævdet i Bang 1932, 131). Under de dystre udsigter i sommeren 1843 til en hessisk prins' giftermål med en russisk prinsesse, hvorefter de to ville kunne ende som dansk kongepar, hvis kronprins Frederik (VII) døde barnløs, ønsker Grundtvig sig af dronning Caroline Amalie "en Hytte mellem Norges eller Northumberlands Bjærge, hvor min Afkom, fribaaren som jeg, kunde aande i Guds fri Luft og tænke og tale i Fædrenes Nordiske Aand" (brev af 17. august, Grundtvig 1891, 214).

234 Aser og Alfer og Dværge] disse tre grupper - hvis virke skal være billeder på havets bølgegang - er i mytologien bekendt som gode og opfindsomme håndværkere, aserne især på Idamarken før krigen med vanerne (Resens Voluspa 1665, str. 7) og de andre i fortællinger fra og om en art under- og lokalmytologi, der resulterede i en række kostbare ejendele til gudernes brug, fx Mjølner og Skiðblaðnir (jf. opregningen senere i Nordens Mythologi, US V, 549-554).

235 hvad Hænder kan naae] måske atter platonisme (jf. v. 208, 254).

236 Selv] endog; meningen er vel, at tanke, tro og vidskab hæver sig fra det synlige til det usynlige og dermed også anbringer sig over ørnen $i$ verdensasketræet Ygdrasills top (udtrykket er identisk med de to manuskripters, Fasc. 388.135-136).

236 hvad Ørnen i Høiheden saa] i Ygdrasills grene sidder en ørn, der véd mange ting ("margs vitande", Resen 1665, fabel 14, jf. eddakvadet Grimnismál, str. 32: "Ørne-Beskeed", US V, 527), og som derfor afbilder "Menneske-Aanden i sin høie Flugt" (528, jf. v. 223 og 229, jf. Flor 1839, 197).

237 Odel] egentlig ret til at arve jordejendom; arv og eje.

238 levende Ord] herved forstås efter sammenhængen først og fremmest mundtlighed. Senere i Nordens Mythologi tolker Grundtvig Urdas kilde som et symbol på poesien i sin højeste grad og i sit oprindelige væsen som profeti udtrykt i en "levende Ord-Strøm" (US V, 532). Modtagersiden afhandles under Odins trone Hliðskjálf, der udlægges som "Lytte-Høien": "Sagen er nemlig den, at Hørelsen unægtelig er Hoved-Sandsen for den Historiske Poesi, ligesom Synet for den Naturlige eller Oprindelige, saa Norden har egenlig ingen langsynede 
Seere, men kun lydhøre Skjalde, og at det er giennem Øret, Odin faaer sin Viisdom, beviser saavel hans Spørgsmaal til Mimers Hoved, som hans Lytten til Hugin og Munin" (US V, 598). I bogens Indledning medtages en hel lille sprogfilosofi med udgangspunkt i Bibelens ti bud, nadver- og dåbsindstiftelsesordene og trosbekendelsen (US V, 425-429, jf. Grundtvigs mageløse opdagelse i 1825). Nøgleordet er "et lyst og levende Begreb om Aand, som den høiere Livs-Kraft, der har sit levende Udtryk i et tilsvarende mundtligt Ord", der sammesteds kaldes "det usynlige, vingede Ord" (427, jf. note til v. 244).

240 Fenris at løse] aserne bandt Fenris-ulven med en tynd, men meget stærk lænke (Resen 1665, fabel 29), men i Ragnarok kommer den løs (fabel 48: "verdur (...) laus") som følge af almindeligt jordskælv og opsluger Odin, der dog omgående hævnes af sønnen Vidar.

241 Faderen] ulven var søn af Loke.

242 bruge sin Mund] ordspil på udtrykket "at bruge mund". Konkret betyder det at bide, som ulven ifølge Snorre gør det ved at at gabe over hele verden, så underkæben hviler på jorden, mens overkæben når himlen, og Snorre tilføjer endda, at hvis der havde været mere plads, ville den have gabt endnu højere (Resen 1665, fabel 48). Overført betyder det at skælde ud på eller at skændes med, men Grundtvig forædler denne faste vending til at angive asernes beherskelse af ord og sprog (jf. allerede v. 165).

243 Brage og Thor] Brage er vis, veltalende, opfindsom med ord og den største skjald, som digtekunst er opkaldt efter (Resen 1665, fabel 24), mens Thor i den skriftlige overlevering er bekendt for fysisk styrke med tilhørende genstande (hammer, handsker, bælte) (Resen 1665, fabel 19), men ikke for sit åndsliv. Kombinationen af de to i én og samme programmatiske verslinje er lidt mærkelig, og senere i Nordens Mythologi undrer Grundtvig sig selv over, at han har besvær med at finde hjemmel $\mathrm{i}$ mytologien for Brages påståede fremragende egenskaber (US V, 661-665, 669-670).

244 det vingede Ord] udtrykket er ikke hjemlet i nordisk mytologi. Grundtvig anfører senere i Nordens Mythologi i et af de frit tolkende afsnit, at Frejas smykke Brisingamen og hendes fjederham og hendes broder Frejs vidunderskib Skiðblaðnir er skabt af lysalfer som "Poetiske Værker af den Himmelske Konst, der ikke afpræger sig i Træ og Malm, men udtrykker sig i det levende Ord, som altid har Vinger, og forherliger Alt hvad det gladelig omslynger" (US V, 550-551). Altså er det Grundtvigs egen betegnelse for frie, inspirerede og mundtligt udtalte ord (modsat jætternes brutale tvang over for sproglige ytringer, jf. v. 163). Passagen er nok ment som et angreb på den personlige censur, som Grundtvig efter den tabte injuriesag imod H.N. Clausen i 1826 var underlagt, og som skulle vare frem til årsskiftet 1837-38.

245 drilles med Vid] dette forstod Loke at gøre gang på gang, hvorved han vakte aserne til dåd og kamp, mest udpræget i eddakvadet Lokasenna, hvor han fornærmede dem en ad gangen (jf. det summariske referat $\mathrm{i}$ Resen 1665, fabel 58). Både i det mytologiske sørgespil Baldur hin Gode, 1807, og i digtet "Lokes Svig" fra digtkredsen Nordens Guder, 
1819, fremstiller Oehlenschläger Loke som en kvik underholder, der keder livet af sig blandt de monotone og ensidige, men selvsikkert og selvfølgeligt handlende gudeskikkelser og for spændings skyld som en asernes surdej sætter dem i både komiske og dødsensfarlige situationer, han så må tvinges til at hjælpe dem ud af igen.

247 for Alt hvad der stammer fra Aand] en tidligere version i manuskripterne A og B har "for Uaand saavelsom for Aand" (Fasc. 388.135, jf. PS V, 521, Fasc. 388.136 har "Aand" og "U-Aand"). Formuleringen har Grundtvig imidlertid kasseret til trykket (se Efterskrift her).

248 arges] vredes, bliver værre (jf. ordsproget "Som man ældes, saa arges man").

249 skinbundet] kun tilsyneladende bundet og uskadeliggjort.

249 i Løn] hemmeligt, i det skjulte (og derfor des mere overraskende og farligere).

250 Tæmmes alene] i nogle myter har Loke frit spil, fordi Thor er optaget andetsteds, men Thors sluttelige tilsynekomst får ham regelmæssigt bragt til tavshed (fx eddakvadet Lokasenna).

250 Thor-Karmens Døn] Thor kørte over himlen eller fra himlen til jorden og tilbage igen i en kærre trukket af to gedebukke (Resen 1665, fabel 19). I eddakvadet Lokasenna dukker Thor til slut op til drikkelaget hos Ægir for effektivt at sætte den ordsnilde og provokerende Loke på plads, der således kun kan "Tæmmes" ved Thors asekraft, ikke med bånd og lænker, og $\mathrm{i}$ forvisning herom kan Grundtvig lade Loke og Thor få samme handle- og ytringsfrihed. Senere i Nordens Mythologi tolker Grundtvig vognen som billede på "Tidens Løb paa KæmpeBanen" (dvs. i heltenes liv, US V, 627). Karm er i øvrigt på ældre dansk og i folkevisesprog en lukket vogn (karet), eventuelt med forhæng (hængekarm), og den synes navnlig brugt af (fornemme) kvinder, så Grundtvigs specificering er næppe historisk sandsynlig (jf. fx US V, 627 og 641). På islandsk bruges ordet "reið”, køretøj (Resen 1665, fabel 19: "Reid"). I 1808 anfører Grundtvig blot "Kerren (Vognen)" (US I, 349). Bestemt af versrytme og rim veksler Oehlenschlägeri i "Thors Reise til Jothunheim" i Nordiske Digte, 1807 (og i optrykket i Nordens Guder, 1819) mellem ordene "Kerre" og "Karm", som han vist anser for synonyme. Etymologien "torden" af "ThorDøn" er rimelig nok (jf. US V, 416), men Grundtvig er udmærket klar over, at hans skriftlige mytologiske kilder slet ikke behandler Thor som tordengud. I 1846 skriver han, at "de nyere Mythographer", der forklarer rumlen fra Thors kærre som torden og hans hammerslag som lynglimt, har "gjort det paa deres egen Haand" uden "mindste Vink derom" i myterne (Grundtvig 1847, 187-188, jf. Vries 1957, 147, 150). Det rammer så også Oehlenschläger, der i 1807 (og 1819) havde ladet Thor køre i det himmelske under tordenbuldren og lynglimt. Grundtvig hævder videre, at når Thor arriverer til tvekampen med Hrungner under ild og torden, er det heller ikke ægte mytisk (Resen 1665, fabel 55: "Elldingar og (...) Thrumur stórar", hvad der kan suppleres med 16 svulstige linjer om det samme fra pjóðólfr 
hvinverskis skjaldedigt Haustlöng, US V, 632-634). For hvis man gør Thor til "den naturlige Tordner", stræber man at sprænge denne trofaste Jordens søn i luften og med ham hele den nordiske mytologi, "og det er, poetisk talt, netop det Samme, som naar man, paa sin Tydsk, stræber at forvandle hele Menneske-Historien til et Skyggebillede af den saakaldte Verdens-Natur og af den rene Tydske Fornuft" (Grundtvig 1847, 188). Med andre ord, hvad Finn Magnusen forsøgte i sin eddaforskning (se her især note til v. 99, 100, 108). Betegnelsen mytograf er fra Grundtvigs hånd nedsættende (om en flittig skribent uden dybere indsigt).

251 Ædlinger] Steffens fastslog i sin 1. filosofiske indledningsforelæsning 1802, som Grundtvig påhørte, at ægteskabelig kærlighed er ædlere end absolut individualisme, at familiekærlighed er endnu ædlere, og at "Nationalismus" er det højeste og ædleste, når det gælder jordiske værdier; fundamental er en egoistisk drift, der går ud på at sikre det individuelles tilværelse i dettes "ejendommelige, specifike Væsen" (Kondrup 1996, 22, 15).

252 Særhedens Skiær] billedet af strand og hav bevares med det lidt forbløffende skærgårdsglimt. "Særhed" må være egenkærlighed, selvrådighed, egoisme. Denne brug af ordet, som ikke er registreret $\mathrm{i}$ Ordbog over det danske sprog (ODS XXIII, 1946, sp. 130), udlægges senere i Nordens Mythologi som følger: lad os stræbe "som Nordiske Mænd, med forenede Krafter, med giensidig Opoffrelse af alt det Scerskildte, som ikke Ærlighed og Sanddruhed helliger, og som derfor ei er mindre uforeneligt med den sande Klogskab end med den ægte Kiærlighed!" (US V, 396). Endnu senere lyder det om den nordiske havbaserede kulturs fortrin frem for landmagters kultur, "at til Søes, baade dagligdags, og i al Slags Kamp, betyder Enkelt-Manden langt mindre, altsaa den foelles Menneske-Aand langt mere end til Lands, hvoraf atter følger, at Enkelt-Mandens Ærgierrighed og Egen-Nytte har langt mindre Spille-Rum til Søes, og nødes til at indhylle sig i Omhu for fælles Ære og det almindelige Bedste, saa, hvordan det gaaer, beholder Aanden her dog Mest af Æren, og Menneskeheden høster den største Fordeel" (US V, 452). Allerede filosoffen Tyge Rothe, som Grundtvig for alvor fik øje på fra sommeren 1812, bruger i et forsøg på at fremelske dansk- og nordiskklingende ord i stedet for fremmede udtrykket "Særvæsen" for "individ" eller "enkeltvæsen" (Rothe 1795, 3). Senere i digtet "Folkeligheden", 1848, sammenfatter Grundtvig en hårdnakket egoistisk gennemførelse af ejendomsret til materielle goder kombineret med manglende sans for et åndeligt og historisk funderet fællesskab i begrebet "Dragedukker" (se også note til v. 216). Denne nuance kan være inkluderet i hans afstandtagen fra "Særhed". En biografisk tolkning af ordet og begrebet som gående på Grundtvigs eget sære litterære væsen er, om end lidt tøvende, foreslået af Poul Borum (Borum 1983, 56), mens Begtrup er gået uden om problemet med sin almindeliggørende parafrase: "ikke være saa snæversynede" (Begtrup 1907, 128). 
255 det glubende Dyr] Fenris-ulven (jf. note til v. 242). Senere i Groesk og Nordisk Mythologi for Ungdommen tolker Grundtvig ulven som "den lave, umættelige Egennytte" (Grundtvig 1847, 216).

256 det Ædle] i Ragnarok skal Fenris-ulven sluge Odin (Resen 1665, fabel 48).

257 Tyr] krigsguden Tyr lagde sin højre hånd i gabet på ulven som pant på asernes ærlighed, da de skulle binde den, og fik hånden bidt af, da ulven blev klar over, at den var blevet narret til at lade sig lænke (Resen 1665, fabel 29). Der kendes ikke andre mytiske træk fra Tyrs virke. Tyr kan således stå for åndens dyrekøbte sejr over jættematerialismen. Senere i Nordens Mythologi grubler Grundtvig ret forgæves over hans funktion og væsen og ender med en antagelse af, "at han modsættes paa Aandens Vegne den Dyriske Glubskhed, og udtrykker Ares-Begrebet, som netop er hvad der adler det personlige Mod" (US V, 660). I 1847 i Grask og Nordisk Mythologi for Ungdommen identificeres Tyr uændret med "Aren, som allevegne, med meer eller mindre Opoffrelse, lægger Baand paa den lave Egennytte" (Grundtvig 1847, 216-217).

258 kun] dvs. Loke må nøjes med at håne den modige krigsgud og kan ikke hævne sin søns ydmygelse; den vaklende intelligens står tilbage $\mathrm{i}$ magtesløshed (hvad der kan erindre om, at han var fader til Hel, den åndelige død, jf. US V, 703). Før Ragnarok er Loke ikke for alvor farlig og skal derfor have lov at virke under opsyn.

Tillag om Slutninger på rimbrevet $i$ manuskript $A$ og $B$ (Fasc. 388.135-136)

Efter henholdsvis v. 214 og v. 218 i trykket fortsætter manuskripterne A og B med oprindelige og indbyrdes afvigende slutninger på "Rim-Brev". De er gengivet $\mathrm{i}$ en idealkombination af Svend Grundtvig i dennes egen retskrivning ( $P S \mathrm{~V}$, 521-522); nedenstående citater er på det punkt korrigeret efter de to separate håndskrifter. A's slutning omfatter 13 parrim, altså i alt 26 verslinjer, placeret præcist på manuskriptets sidste side. B har ikke A's sidste parrim (citeret nedenfor), men består i øvrigt af 20 parrim, altså $\mathrm{i}$ alt 40 verslinjer. Samtlige parrim er mandlige med undtagelse af "Bjerge - Dværge" $\mathrm{i}$ både A og B, svarende til trykkets v. 233-234. Ingen af udkastene er daterede, men den ved overstregning ændrede titel på rimbrevet i A indføres i $\mathrm{B}$, så $\mathrm{A}$ må være ældst, en kladde over for en redigeret renskrift.

A og B er enige om 4 indledende verslinjer, der behandler modsætningen mellem de ædles begreb om frihed over for trangen til "Tvang" hos "de Dumme og Slette". Den skal disse imidlertid have lov at beholde i fred, "Thi kun den Frihed kan baade en Stat, / Som den kan skiænke de Slette uskadt" (dvs. uafkortet; baade $=$ gavne). Dette tolerance-afsnit savnes i trykket. A fortsætter med det ret tomme parrim: "Frihed til Alt, hvad der gavner et Land, / Frihed til Alt, hvad der egner en Mand". B indsætter i stedet linjerne om Lokes, men ikke Fenris', ret til at bruge mund (svarende til trykkets v. 241242 og 245-246, men uden v. 243-244 om Lokes ytringsfrihed på linje med Brage og Thor modstillet jætternes fængslen af vingede ord). 
Herefter følger i både A og B 2 verslinjer med første udkast til det berømte sted om ligeret for Loke og Thor (trykkets v. 220, jf. 243, 247) formuleret som "Frihed for Uaand saavelsom for Aand" (A; B fremhæver "Aand" og staver desuden "U-Aand"). Denne version kommer ikke på tryk. Videre bringer A kun, hvad der svarer til trykkets v. 247-248, idet dog v. 248 med ændres og arges ved bånd oprindeligt har lydt: "Der ei kan tvinges kun tirres ved Baand" (med konsonantisk bogstavrim i stedet for vokalisk). A udelader således trykkets v. 249-250 om det bundnes ugerninger og Thors hævn. B fortsætter derimod svarende til trykkets v. 248-250 (om det underkuede åndelige, der kun bliver værre ved bånd og gør den værste udåd $\mathrm{i}$ hemmelighed, hvad Thor må stoppe). Begge udkast fortsætter svarende til trykkets v. 221-222 (frihed for ordet i en ny verden just skabt dertil). A har en overstreget formulering af det, der svarer til trykkets v. 221, nemlig "Frihed for Ordet i Kredsen det slaaer", en understregning af menneskeordets kraft. Trykkets v. 222: "Som til sig selv det har skabt under Sky" hed i udkastene "Som Det har underlig skabt under Sky", hvor "underlig" formentlig betyder "ved et under; underfuldt, mirakuløst"; det skabende menneskeord har således oprindeligt været beskrevet $\mathrm{i}$ en mere bibelsk ånd, med en ikke-meningsgivende lydlig gentagelse i "underlig" og "under Sky". I opregningen af den nye verdens tre åndsområder (trykkets v. 223 og 229) har A som tredjeled begge gange "Følelsens", mens B har "Vidskabens". Det oprindelige ville have givet en trehed i bedre overensstemmelse med Grundtvigs vante psykologiske menneskemodeller (Grønbæk 1951, 74-105), så det trykte kan tolkes som en fremhævelse af menneskeåndens områder (fag) mere end af dens væsen (bestanddele). De friske billeder af humanismens land/strand og hav i A og B svarer til trykkets v. 224-236, A mangler parrimet med mottoet om kamp (v. 227-228), som kommer ind i B efter, hvad der svarer til trykkets v. 226 (hvad Svend Grundtvig dog ikke respekterer i sit selvkombinerede tillægstryk i $P S \mathrm{~V}, 521)$.

A slutter med et parrim efter, hvad der svarer til trykkets v. 238 (om ærefrygt i hele Norden for det levende ord): "Vækker, som Gudernes Gaard i Nord, / Priis og Forundring trindt paa Jord!". Det er en tom og temmelig forfejlet udgangspointe, eftersom Nordens Mythologi ikke var beregnet på at gøre opsigt over hele verden.

I B har Grundtvig forsøgt en mere filosofisk slutning. Først svarer den til trykkets v. 251-252 (advarslen imod særhed), derpå kommer 2 ikke-trykte moraliserende vers (vedrørende ikke at kives om, hvem der har ret, men at bekæmpe alt slet), og endelig følger svarende til trykkets v. 253-254 en opfordring til kun at "bekæmpe" (rettet til "bestride") det åndelige med ånd. Efter et tydeligt kolon i stedet for trykkets udråbstegn (som udgang på v. 254) hylder B's 4 afsluttende verslinjer "Ordet" (PS V, 522). De er dog ikke vellykkede, fordi det i positiv hensigt sker gennem negativt klingende udtryk: "drypper af Skarn" (en af ordets mulige egenskaber), "under Soel" (verdslig forgængelighed, jf. Præd 1,14), "vanartigste", "spotte", "hver Dødeligs Haand" (det indskrænkede menneske). I fjerdesidste linje har Grundtvig arbejdet med en positiv indrømmelse ("selv"), der ændres til en negativ accept ("vel"). Tredjesidste linje har voldt besvær. Først har Grundtvig skrevet om det misbrugte levende ord, at det "Altid", hvad der afbrydes og 
rettes til "Dog kun er Aandens vanartige Barn", som igen rettes til "Er under Soel det vanartigste Barn" (Svend Grundtvig har fejlagtigt "uartigste", PS V, 522). Positivt er "Ordet" dog tilskrevet "Vinger" og herkomst fra "Aand". Men det afsluttende parrim lader "Haand" være digtets sidste ord. Det omvendte havde været bedre. Med rette har Grundtvig ladet denne afslutning blive i kladden.

\section{Efterskrift}

\section{Tilblivelse}

"Rim-Brev til Nordiske Paarørende" er sammen med den øvrige Nordens Mythologi forfattet i 1831-32 efter Grundtvigs hjemkomst 31. august 1831 fra den tredje Englandsrejse. 29. oktober 1831 meddelte han Gunni Busck sin plan om at udsende en ny udgave af Nordens Mytologi, 1808 (BG II, 201). Til Ingemann skriver han 7. januar 1832, at hans Indledning til værket har optaget ham i de sidste tre måneder og er blevet til ved flere gennemskrivninger (Grundtvig 1882, 130131). Busck underrettes 21. januar 1832 om, at Indledning skal fylde 12 ark, men at Grundtvig har skrevet 40 (Bech 1878, 137-138), altså 192 sider over for 640, omredigeringer giver et endnu højere tal (Thaning 1963, 256, note 24). Grundtvig erklærer hele bogen for færdig pinselørdag 1832 (9. juni), hvor et ret personligt bekendende udkast til Fortale skrives (Thaning 1963, 285-288), som dog omarbejdes til en mere objektiv version dateret 12 . august, den sandsynlige begyndelsesdato for trykningen. Bogen godkendtes af censor Thomsen fra Københavns Politieret 1. december 1832 og udkom 22. december. Oplagets størrelse er ukendt, men et par år tidligere blev Grundtvigs bøger gerne trykt i 500 eksemplarer. En forlagsopgørelse fra 1859 inkluderer usolgte eksemplarer. Året efter Grundtvigs død er originaludgaven som de fleste større Grundtvig-udgivelser før 1850 udsolgt; et uændret optryk var dog fremkommet i 1870 (Johansen 1951, 72-75, SJ I, 288). Forlaget var i begge tilfælde J. H. Schubothes Boghandel.

\section{Nytrykket}

Teksten er gengivet efter originaltrykket, som er i kursiv med udhævelser i ordinær - det er der dog her byttet om på. Ligeledes er ö overalt udskiftet til ø. Den originale paginering er i romertal (III-XII); sideskift indtræder med v. 25, 48, 71, 99, 122, 149, 177, 204 og 232. Grundtvigs egne 5 fodnoter er markeret med asterisker, hvad der er fulgt her; 2 står på s. IV, 2 på s. V og den sidste på s. VI. Tekstens 7 afsnit er her markeret af udgiveren med romertal i klammer. 


\section{Manuskriptmateriale}

Til Nordens Mythologi generelt er der bevaret et meget omfattende manuskriptmateriale i Grundtvig-arkivet på Det Kongelige Bibliotek (Fasc. 269-277, omkring 900 sider). Gennemgangen af disse fylder en væsentlig del af bind I af Kaj Thanings disputats (Thaning 1963, 107256). Til "Rim-Brev til Nordiske Paarørende" er der kun overleveret to manuskripter i Fasc. 388.135-136, der omfatter i alt 16 beskrevne kvartsider. Begge er kortere end trykket, men hele hver for sig. De er under benævnelsen $\mathrm{A}$ og $\mathrm{B}$, som med blyant er påført manuskriptlæggene, i udvalg indarbejdet i noter eller til dels trykt af Svend Grundtvig i 1883 (PS V, 512-519; 521-522). A har færre understregninger af ord, færre sætningstegn og flere rettelser ved overstregninger end $\mathrm{B}, \mathrm{A}$ har ingen fodnoter. $\mathrm{B}$ er en redigeret renskrift med fodnoter indsat, men er ikke trykmanuskript.

\section{Form}

Fraregnet titlen består digtet af 258 verslinjer, der ved blanklinje typografisk er opdelt i 7 afsnit af vekslende (indholdsbestemt) længde (v. 1-30, 31-52, 53-66, 67-108, 109-136, 137-198 og 199-258). I manuskripterne $\mathrm{A}$ og $\mathrm{B}$ er der oprindeligt blanklinje også foran trykkets v. 23, og A har ikke blanklinje efter v. 66, men derimod efter v. 74.

Verslinjerne har alle 4 trykstærke stavelser, med rytme varierende mellem trestavede (daktyliske) og tostavede (jambiske) versefødder. Alle trykkets verslinjer har enderim, de 111 er parrim, mens der er 9 passager med 4-linjede krydsrim. Det signalerer en meget frit forstået rimkrønikestrofe med afgjort overvægt på kvikt indfaldende parrim. Et nøjere princip for fordeling af rimene kan næppe skimtes $i$ det blandede slutresultat. Digtet begynder og ender med en 4-linjet passage, og kun afsnit II består af lutter parrim. Mandlige rim er i absolut overtal, hvad der forstærker tekstens karakter af energisk vækkersang eller anråben, de i alt 9 kvindelige rim er i 7 tilfælde anbragt i de krydsrimede 4-linjede afsnits 2. og 4. verslinje og i 2 tilfælde i parrimede linjer (v. 101-102, 233-234). Grundtvigs formentlige forbillede, Jens Baggesen, arbejder med en meget mere ligelig fordeling af mandlige og kvindelige rim med en blidere tone til følge. Grundtvigs mange mandlige rim sikrer en god rimkvalitet, øjerim er anerkendt i tiden (v. 101-102: "Balder - falder"), tvivlsomt er vist kun rimet v. 217-218: "af Adelskab" (hverdagstalesprog eller dialekt med "-au"?). Af par-rimene i de to udkast til slutningen i A og B er kun 1 kvindeligt (svarende til v. 233-234). 


\section{Genre}

Teksten kalder sig et rimbrev. Skønt denne - oprindeligt antikke genre i Danmark kan dateres tilbage til barokken fra og med 1660'erne (Albeck 1971,7), forbindes den i 1832 navnlig med Jens Baggesens omkring 100 personorienterede digte, "Vers, som jeg har trukket ud og ind, / Alt efter Musens løierlige Sind" (Arlaud 1891, 10). Disse epistler skal underholde, og i 1814 erklærede Baggesen, at han "ei det lange Store / Kan lide; thi det morer ei" og "ei det store Lange / Kan udstaae; thi det keeder tidt" (Arlaud 1903, 257); Grundtvigs i samme år udgivne Roskilde-Riim kan derfor ikke have bekommet ham vel. Med Baggesens rimbrevgenre har Grundtvigs rimbrev fra 1832 imidlertid ikke stort til fælles. Grundtvig vil hverken more eller kede, men vække og forkynde og er dermed langt mere i slægt med dele af monologerne i den gamle danske Rimkrønike, 1495, som han da også fra og med 1814 var levende optaget af. I 1834 måtte Grundtvig indrømme, at han havde læst Rimkrøniken vel nok 200 gange og kunne den meget bedre end Bibelen (Grundtvig 1834, sp. 549-550). I anledning af C. Molbechs sproghistoriske udgave fra 1825 havde Grundtvig i 1826 arbejdet særdeles intensivt med rimkrøniken og skrevet en indgående, desværre aldrig optrykt anmeldelse af nyudgivelsen over numrene 13 og 15-18 af avisen Nyt Aftenblad (april-maj), og et omfangsrigt arbejdsmateriale fra sagen ligger utrykt og delvis ustuderet hen i Grundtvig-arkivet (Fasc. 288.1-6, se dog Toldberg 1954, 61, 64-71).

At teksten er en påkaldelse, slås fast gennem gentagne, let varierede tiltaler af adressaterne: "Sønner og Døttre af Nordens Aand" (v. 1), "Sønner og Døttre af ham i Nord" (v. 23), "I Børn af Kæmpe-Æt" (v. 137, jf. v. 206: "Menneske-Børn"), "Sønner af Kæmpe-Æt" (v. 199), "I Ædlinger" (v. 251). Til disse rettes tvivlende spørgsmål (v. 23-30, v. 53-66, v. 67-108), som dog afvises (v. 109-136). Det er værd at bemærke, at Grundtvig ikke glemmer piger og kvinder i sin opsang (jf. v. 129-132); senere i Nordens Mythologi nævner han også kvinderoller eller kvindefunktioner (US V, 464-466, 500, note ${ }^{*}, 678$, 730 med note ${ }^{* *}$ ).

Den kaldende afsender - Grundtvig som forfatter til Nordens Mythologi - identificerer sig selv som "en Broder" (v. 26), der forhåbentlig ikke er den eneste og sidste fortaler for Nordens ånd (v. 29-30). Han har personlige erfaringer med England (v. 31-52), men er ægte dansk digter (v. 38, 41), nu en ældre mand (v. 48 - han var i 1832 49 år). Han repræsenterer "en Nordisk Røst" (v. 58), ud fra en sikker fornemmelse for og sikker viden om åndelige fænomener ("vist jeg veed", v. 109), som bare skal forstås "ret" (v. 138, 200). Derfor beder han om "Svar" (v. 27) og ørenlyd (v. 138). Han er rede til et slag for sin sag (v. 141, 157), men også tolerant over for de vildførte mod- 
standere, fordi deres nederlag er sandsynligt, deres horisonter utilstrækkelige (v. 166-198). Han besidder "sund Forstand" (v. 207), styrket med dampkraftens motto: "mit Liv er i Kamp!" (v. 228). Men afsenderen har brug for en respons på sit "Rune-Maal" (gådetale) for at forvisse sig om, at han ikke er en enegænger (v. 27-30). Ligger der måske her en svag antydning af den døende hundredårige Ossian, der som den allersidste husker fortidens store bedrifter? Eller af den blinde "Mythe-Smed" Thamyris ved det isthmiske høstgilde (jf. US V, 438439)? Eller af den anonyme gamle kriger, der som den sidste af sin generation begraver sit livs guldskatte, som så siden Bjowulf vinder fra dragen (jf. Grundtvigs digt "Nordens Guld", 1834, trykt 1849, PS VI, 41-43, samt Forord til Skov-Hornets Klang mellem SkamlingsBankerne, 1844, US IX, 27, hvor han fortryder pessimismen i det da utrykte digt)?

Grundtvigs interesse for mundtlig kommunikation illustreres i lydfænomener, der forbereder digtets afrundende filosofi om det levende og vingede ord (v. 221-254). Negativt omtales hans engelske adressaters manglende hørelse (v. 38), hans egne dumpe harpetoner (v. 42) uden naturlig lethed (v. 43-44), hans ulyst til at lalle på engelsk som et lille barn (v. 45) eller blive skoledreng igen (v. 47-48), alt sammen resulterende $i$, at han ikke er i stand til at kontakte åndsfæller på engelsk (v. 49-52). Videre negerer han prøvende lyden af en nordisk "Røst" (v. 58), som er blevet en hvisken (v. 59) om det hæslige og uædle i nordisk oldtid. Ædle nordiske "Trylle-Navne" (v. 83) fremstår som måske "tomme Ord" (v. 84). Positivt håber han på "Øre" (v. 25) for Nordens ånd og har i England fundet ekko (v. 34) og knurren (i stedet for kvad) (v. 35-36) af det gammeldanske. Mismodet på vegne af Nordens ånds nutidige børn fejes senere i digtet til side af håndfaste vidnesbyrd fra Danmark og Norden om digtning, sang og lytten gående over i tilegnelse ved børns leg og i unges ambitioner (v. 121, 123, 131, 133-134 og 135-136). Han vil høres (v. 138) - som han skrev i "Paaske-Lilien" i 1817: "Døve sig hvem ei vil lytte!" (DV II, jf. US III, 438).

Digtet tilvejebringer en dialog mellem adressaterne og afsenderen. En suggererende forening af kræfterne sker ved overgang fra "jeg (mig, min, mit, mine)" (sidste gang v. 138) til "vi (vor, vort, os)" (v. $85,118,157,162,165,168,171,200$ og digtet ud).

\section{Komposition}

Den elementære bevægelse fra 1. person ental til 1. person flertal udgør ikke digtets eneste drivkraft. Et righoldigt udfoldet billedsprog, som, skønt stedvis dunkelt og indforstået, vel er et nærmere studium værd, modarbejder reduktion til en simpel grammatisk model. Digtet 
præges ved retoriske gentagelser og genoptagelser af en stadigt strømmende rytme, men undervejs giver Grundtvig sig tid til nedslag og forslag, der sinker og maner til betragtning og eftertanke. Under den konstruerede spontanitet ligger et stykke styret åndsarbejde. Digtet er skrevet som en ouverture til resten af den omfangsrige mytologiske fremstilling, der karakteriseres ved en blanding af solide filologiskhistoriske analyser og dristige subjektive tolkninger og kombinationer. Derfor er der kun få enkeltheder i rimbrevet, som ikke lader sig belyse og opklare et eller andet sted i bogens korpus.

Nedenstående kompositionsoversigt skal sammen med noterne til de enkelte verslinjer og med inddragelsen af nogle håndskriftlige varianter betragtes som bidrag til en nuanceret forståelse af teksten (tidligere oversigter, se Rønning 1927, 243, og Christensen 1987, 204214).

I Afsnit I (v. 1-30) defineres den Nordens ånd, hvis afkom digtet vil nå, $\mathrm{i}$ en række heroiske træk (v. 3-22): de første 12 (se de enkelte noter) får én verslinje hver (v. 3-14), herefter skildres i 8 verslinjer (v. 15-22) Thorshammerens tilblivelse og bedrift med at knuse romersk røverhånd og romersk ånd i England (= "Herkules", v. 18), et mindesmærke i historien, som er evigt emne for kvad, mens Roms eget krav på evighed ikke holdt (v. 22 og 20). Bedrifterne understreges sprogligt ved hjælp af 16 handlingsverber. Gennemgående for afsnittet er tillige en modsætning mellem "Guld" som en gudekraft (v. 8, 10 (= måske om heliadernes tårer, som dog var rav, ikke guld), 11 (= Frejas gyldne tårer), 13, 14, 15) og "Staal" som utilstrækkelig våbenmagt hos jætter og romere (v. 8, 17-19). Disse betydninger bekræftes senere (v. 79, 98, 189 over for 68). Hele dette afsnit om Nordens ånds heltegerninger får siden i rimbrevet sit modstykke i en langt udførligere beskrivelse af den ægte nordiske ånds fjender (v. 69-108, 110-112 og 141-198).

Stemningen sidst i Afsnit I om Englands befrielse fra Rom fører over i Afsnit II (v. 31-52), der udelukkende handler om Grundtvigs personlige indtryk af England fra de tre rejser 1829-31, udformet i et "Rune-Maal" (jf. v. 29). Minderne fra danskertiden er stadig til stede i London, Exeter og Cambridge, men høres og forstås ikke af sproglige grunde (v. 31-40). På engelsk kan Grundtvig heller ikke digte let og naturligt, og "Røsten" (v. 38), "Skjalde-Tungen" (v. 41) og en dristigt løftet "Stemme" (v. 49) preller af på de indfødtes mur og bom (hvad han attesterer $i$ en fodnote med et direkte citat fra engelske venner $i$ Cambridge). Det afvisende i England understreges ved gentagelser ( $\mathrm{v}$. 39, 49, 51: "der") og variationer (v. 41: "hist", v. 51: "paa fremmed Grund") og ved nægtende og indskrænkende ord (v. 32, 38, 43: “ei”, v. 40, 46, 51: “ikke", v. 42, 50: "kun”). Receptionen af Nordens ånd i nutidens England var dermed ikke det hurtige "Svar" (v. 27), den 
broderlige afsender havde behov for at høre. Det opfordrende udråbstegn (v. 30) var forgæves.

I Afsnit III (v. 53-66) flyttes fokus derfor efter et "Men" tilbage til Norden med anaforerne "Her" (v. 54, 57, 58) og et tvivlende spørgsmålstegn til slut (v. 66). Problemet er, om sansen for Nordens ånd er lige så død og indsovet i det egentlige Norden "nu" (v. 56, 64, jf. videre 70, 73, 84), som den er i England.

Afsnit IV (v. 67-108) bliver - stadig i spørgeform (v. 67, 75: "Hvad?"; spørgsmålstegnene v. 84, 88, 92, 96 og 108) - en opregning af en mulig søvnig og død stemning hjemme i Norden. Den romerske jætte blev knust (v. 17-21), men er Norden alligevel nu i jætters magt (v. 67) og dødsgudinden Hel den ypperste gudinde (v. 69-70)? Der opremses en række gammelkendte berømte træk og navne fra Nordens natur og geografi (se noterne): England (v. 73-74), Danmark (v. 7578), Sverige (v. 79-80) og Norge (v. 81-82). Det munder ud i et spørgsmål om, hvorvidt disse "Trylle-Navne" er blevet tømt for indhold (v. 83-84). De 10 positivt ladede verslinjer făr nu overvældende modspil i beskrivelsen af de "tomme" og altså ikke-fortryllende fænomener på 12 verslinjer. Det gælder træk fra banalt og uåndeligt hverdagsliv, der i nuet fremstår som en sørgelig arv i forhold til oldtidens (anaforisk ved verbet "Levned(e)", v. 85, 89, 93). Også de er arrangerede efter de enkelte nationer (se noterne): Danmark (v. 85-88), Sverige (v. 89-92), Norge (v. 93-96), mens England blot strejfes som udland i baggrunden (v. 85 og 95). De parallelle kolonner (v. 73-82 over for v. 85-96) konstaterer som samlet facitliste således en beklagelig degeneration i nutiden. Således indretter "kloge Dyr" (v. 104) sig. Den bedøvende opremsning af usamhørige enkeltheder udtrykkes sprogligt i 55 substantiver, hvoraf 14 endda er sammensætninger. Tilstanden synes blottet for håb om udvikling til det bedre.

Afsnittets sidste verslinjer (v. 98-108) søger årsagen til tomheden i Nordens befolkning selv, fordi de, der "gløded for Oldtids Guld", udvandrede eller døde fra indsigter, der var rigtigere end de herskende. Dette forhold fremstilles 10 linjer i træk med ligeledes mange substantiver. I gentagne sammenligninger foretrækker fortælleren noget åndeligt dybt (Odin, Aand, Graad for Balder, Myther, Folk, Kamp, Hald, Liv, Ygdra-Sill) for noget hverdagsagtigt eller overfladisk (Luft, tydsk Fornuft, fugtig Dug, Æventyr, kloge Dyr, Knald og Fald, Skin, Lykke-Spil, Gas). Det hele ender dog stadig i et spørgsmålstegn (v. 108).

Efter denne deprimerende analyse af nutidens nordboer bringer Afsnit $V$ (v. 109-136) en virkningsfuld modbevægelse. Spørgsmålene i Afsnit III om nordisk nutids dødsdrift og dødsdyrkelse og i Afsnit IV om jættematerialismens sejr relativeres med almengørende ord (v. 110: 
"altid", 111: "immer"), med et norrøniseret bibelcitat om den brede vej til Hel og med en betragtning af de fleste menneskers jævne forstandsniveau (v. 109-112); lidt senere følger en kassation af skiftinger (v. 115-116), der dør lige så dådløst, som de har levet. Men derpå opregnes kraftige modbeviser fra nordisk og dansk kultur: det islandsk-norske Valhal (v. 113), det islandske Skáldatal (v. 114), folkeviser (v. 121-122), folkevisesang (v. 123), kvadlyttende piger, der snart bliver mødre (v. 129-132), legende drenge, der som unge mænd ønsker sig heltesværd (v. 135-136). Med barsk humor forestiller Grundtvig sig et nutidigt høstgilde som det i Valhal, hvor heltene i Valhal hver dag dræbte hinanden (v. 126: "Naar der indhøstet er paa Val") og genopstod til middagsmaden. Thomas Thaarups festspil fra 1790, Høst-Gildet, var i øvrigt et af Grundtvigs yndlingsdramaer ( $M M$ 1877, 47-53, jf. Thamyris-fantasien, US V, 438-439). Afsnittet holdes sprogligt sammen af to parallelle konstruktioner: "Hvor ... / Sikkert ..." (v. 117, 121, 123 over for 124) og "Ja, hvor ... / Der ..." (v. 129 over for 133, 135). Den talende overbeviser sig selv med superlativer og bekræftende ord (v. 121 "fleest", 122 "Meest", 123 "bedst", 124 "Sikkert", 133 og 135 "vist").

Afsnit VI (v. 137-198) begynder med "ret" at annullere skitsen fra v. 136 af den sværdbevæbnede ungersvend ved at meddele, at krigeren er billede på en åndelig helt, faktisk en regulær allegori. Programmet er åndskamp, hvor sværd = tunge, spyd = pen, skjold = vid og dåd = dyd (v. 139-140, jf. v. 253-254). Slaget (v. 41) - som nok er både kampen og hammerslag af Mjølner (jf. v. 157) - gælder ikke fysisk liv og død, men rettes imod sindstilstandene last og skam. Modstanderne kaldes "Hunde-Sjæle" i menneskeskikkelse (v. 142, jf. 112 "HundeForstand" og 104 "kloge Dyr"). De bestemmes med ofte anaforisk anbragte stedord "Dem; deres" som udvalgte genstande for nedkæmpning (v. 143, 145, 147, 152, 157, 159, 161, 164, 166, 167, $169,172,173)$. Der berettes om 4 grove eksempler på overmodige jættehandlinger (v. 143-156, se noterne). Men Grundtvigs holdning er tolerant: det gælder ikke jætternes blotte liv (v. 161-164), når man kan nøjes med overliste dem med ord ("bruge Mund", v. 165, jf. 242) og elegant demonstrere deres magtesløshed ved så at sige at danse uden om deres klodsede manøvrer (v. 166-172) - i luften, til lands og til vands. Tolerancen intensiveres til at lade jætterne frit bevæge sig til deres udvalgte mødesteder på deres primitive transportmidler (v. 173179). Højdepunktet er at give dem ordet direkte (jf. kolonet i v. 179) til en hån over guderne Thor, Odin, Frej og den døde Balder (v. 180-198). Jætter har ikke noget begreb om fortjeneste, og i deres mund er "Lykke" ensbetydende med slumpetræf (v. 190, 196, jf. 107). 
Afsnit VII (v. 199-258) samler og sorterer de erfaringer, de foregående afsnit har gennemgået. Udgangspunktet er forståelsen af et fælleskab, der gavner alle ved at indrømme plads til underordnede forskelligheder (v. 200-201). Det finder udtryk i et ord og begreb, der hidtil ikke er forekommet i digtet - "Frihed" (v. 202, 203, 205, 213, 219, 220, 221, 230, 239 og 247, i alt 10 belæg), hvortil kommer "frit" (v. 215) og "Fri" (v. 243). Nordens ånd er identisk med frihed, og derfor kan den føle sig "seiertryg" (v. 2) og "seierrig" (v. 246).

Frihed defineres derefter på to måder. Den negative og forkastelige frihed er som de ubønhørlige naturelementers anarki (v. 203-204), som rovdyrs destruktive væsen (v. 205) og som materialistiske og mentalt set dyriske egoisters handlemåder ud fra tre motiver: lyst til ondt, hævn på uvenner, misundelse på dem, der har det godt (v. 213-218). Med et andet udtryk introduceret sent i teksten (v. 104: "kloge Dyr" om rationelle og materialistiske mennesker) anslås et tema, der bliver vigtig i rimbrevets slutning (jf. v. 211, 217, 255), det dyriske. Egoisterne er nemlig mere dyr end mennesker, skønt man ikke advares om det af deres udseende, som man gør det i de direkte forskabelser af børn, som onde stedmødre står for i folkeviserne (v. 209-212). Senere i Nordens Mythologi kalder Grundtvig netop et sådant åndløst og dødt menneskebegreb den "dyriske Egen-Kicerlighed og Selv-Klogskab" (US V, 411). Egoisterne praler med at være af åndelig fødsel og åndelig adel (v. 218), men den frihed, de står for, er hverken menneskelig eller medmenneskelig. Frigørelsen af Fenris-ulven til Ragnarokskampen hører under deres regimente (v. 240).

Modstykket til egoisterne er "voxne Menneske-Børn" udrustet med "sund Forstand" (v. 206-207). De opfordres til et andet frihedsideal, der kan dække både de værdier, der findes hos Loke, og dem, Thor står for (v. 220), nemlig henholdsvis drilsk og positivt vækkende og æggende intelligens (v. 245) og jættetæmmende og jættedræbende gudekraft (v. 250); digterguden Brage indføjes også i sammenhængen (v. 243). Friheden gælder ydermere "Ordet i Verdenen ny, / Som til sig selv det har skabt under Sky" på områderne filosofi, tro og videnskabelighed (v. 221-222, 223, gentaget v. 229). Ved at indrømme, at disse fag er blevet til ved menneskets sprogligt skabende digte- og tankevirksomhed, fremtræder Grundtvig som humanist. Den nærmere betingelse for dette nye åndsliv er kappestrid (231), digtets næste nøglebegreb, og den forudsætter kamp (v. 228, jf. 246) og tilladelse til at "bruge sin Mund" (v. 242), med "Ære-Frygt dyb" for denne arv fra aserne (v. 237-238). Menneskeordet er kulturskabende (v. 222), levende (v. 238), vinget (v. 244), tilladeligt (v. 242), når det vel at mærke hæver sig over, "hvad Hænder kan naae" (v. 235, 254), altså 
stammer fra "Aand" (v. 247) og derfor kun findes på et ikkehåndgribeligt niveau (v. 139-140, 235, 253-254).

De tre handlende parter sorteres til slut med det gentagne indskrænkende ord "kun". Det bruges om guderne og deres ædle moderne arvinger (v. 253), om jætteuhyret Fenris (v. 255) og om vakleren Loke (v. 258), der både kunne tirre med vid (v. 245) og spotte uden følger (v. 258). Tyr får æren for det ædles dyrekøbte sejr (v. 257, jf. 237238), men forbliver - ligesom i alle mytologiens kildeskrifter - en bleg skikkelse (jf. Grundtvigs hasarderede identifikation af ham med Uller, US V, 658-660).

Dermed holder rimbrevet op - uden præcis eller prægnant slutning. I en vis forstand er digtet aldrig blevet færdigt (jf. overvejelsen om slutning i og med trykkets v. 238, Christensen 1987, 213). En gennemgang af Grundtvigs to ældre forsøg på at afrunde og pointere digtet bringes her efter noteteksten til v. 258.

Det bekræftende udbytte til samtiden af digtet er understregningen af begreberne Frihed, Ordet, Kappestrid og Kamp - der alle "ret" forstået er forudsætningen for en ny nordisk guldalder. Det er enkle og prisværdige værdier at tilegne sig, som grundtvigianere og folkehøjskoler da også har gjort det i adskillige generationer siden 1832.

\section{Grundtvigs Loke-figur}

Mest problematisk og mest misforstået er Grundtvigs brug af Loke, der tilsyneladende skal have handle- og talefrihed parallelt med Thor og Brage, skønt han er ond jætte og skyldig i Balders død og dermed også i Ragnarok. Som et moderne bevinget ord er erklæringen om hans rettigheder (v. 220, jf. det mindre kendte v. 243) kommet til at betyde, at Grundtvig vil sætte lige vilkår for godt og ondt her på Jorden, en art fair play og gentleman's game-holdning, som den engelskorienterede skjald dog aldrig har formuleret. Tolkningen, som stemmer godt med en udbredt forestilling i det 20. århundrede om det demokratiske ved værdirelativisme, synes uudryddelig og uoprettelig, trods protester fra forskerne, der har fordybet sig i teksten og dens forudsætninger ( $\mathrm{fx}$ Thaning 1963, 284-285, 463, Christensen 1987, 210, LundgreenNielsen 1994, 190-193, og 2007, 76-79). Den er blevet en journalistog politikerklassiker ved siden af Wessels smed, der blev henrettet $i$ stedet for bageren og andre frugter af litterær desorientering.

Hvad mener Grundtvig i 1832 med Loke? Litterært har han Lokefigurer fra såvel Johs. Ewald (1775) som Oehlenschläger (1807 og 1819) i hovedet. I hans egen 1808-mytologi spillede Loke den skæbnesvangre rolle, der var foreskrevet ham i eddakvadene Völuspá og Hyndluljód (US I, 284-285), og var mindre et eksempel på den psyke, digterne tillagde ham. 
Tidens videnskabelige syn på Loke var åndsfattigt og reduktivt. Den islandskfødte oldforsker Finn Magnusen (1781-1847) forstod i 1822 i anledning af sin oversættelse af eddakvadet Vegtamskviða (Baldrs draumar) Loke som "vulkanisk Jordbrand i en Bjerghule". Omskabt til kællingen Tøk vil han som ild derfor kun begræde Balders død "med tørre Taarer", hvad Magnusen udlægger dels som "Gnister, Røg og Aske", dels som "Flammerne hvis høje Toppes Slør (eller Hovedslør) dvs. Røgskyerne nemlig, opflagre mod Himmelen”, og Loke bliver derved (i eddakvadet Lokasenna) forvandlet fra "den troløse, skadelige, fortcerende Ild til Falskhedens, Løgnens og Ondskabens Dæmon" (Magnusen II 1822, 266, 278).

Grundtvig var allerede i 1808 klar over, at Loke aldrig havde haft nogen kult for sig (US I, 268, jf. Vries 1957, 265). Derved bliver der et videre rum for at tolke hans position og funktion. I 1832 har den modne Grundtvig forladt sin ungdommelige romantisk farvede idealisme og sin strikse bibelortodoksi og er blevet klogere på menneskelivet. Det barske religiøse enten-eller, som han konfronterede fx Oehlenschläger og J.P. Mynster med i 1812 (Lundgreen-Nielsen 1980, 522$524,545)$, er blevet et mere humanistisk både-og. Rent teknisk føler han sig fristet til at flække Loke midtover, fordi han netop ligesom grækernes Prometheus har to sider, og fordi der "virkelig findes et saadant tvetydigt Væsen hos ethvert Menneske og hos ethvert Folk, der troer paa Meer end de selv begribe, thi hos dem Alle opstaaer der et besynderligt Forhold mellem Anskuelsen og Troen paa den ene Side, og Begrebet paa den Anden: et Forhold, Loke-Mythen udtrykker saa dybt og træffende, at den nødvendig maa være udsprunget ei blot deraf, men af en Følelse, hvori det dybt afprægede, og en Anskuelse, hvori det klarlig speilede sig" (US V, 702). Den indsigt har bevirket, at Grundtvig lader Loke være uflækket og "gaae for den han er". For ved at binde hænderne på Loke binder man også hænderne på den fornuft, han trods alt repræsenterer, og gør således sig selv skade. I digtet "Tids-Aanden" fra 1834, men først trykt i 1885, gentager Grundtvig synspunktet: "Raade jeg skal med det Samme / Folket af fredegod Stamme / Aldrig trods bidhvasse Ord / Loke at binde i Nord" (Fasc. $389.520 \mathrm{v}-21 \mathrm{r}$, jf. PS VI, 67).

Løsningen for Grundtvig er i 1832, at Loke skal have lov at virke, men under opsyn af vægterguden Heimdal (dvs. en myndighed styret af ånd). Herved vises, "at de Nordiske Myther hænge ligesaa nøie sammen med det Nordiske Menneske-Liv, hvoraf de udsprang" (US V, 703). Loke er kort sagt med sine fejl og mangler et udtryk for åndsliv, og det er årsagen til, at Grundtvig ikke kan bruge sin fortællerstemme i manuskripterne, når den fremsætter en erklæring om "Frihed for $U$ Aand saavelsom for Aand" (forstadium i manuskript A og B til 
trykkets berømte v. 220, her fra den renskrevne version B). Grundtvig har på et tidspunkt i 1831 ment, at videnskabsmænd i Norden, både hedenske og kristne, må have ånd nok til at indvi historiens tempel til "en Helligdom, hvor selv Fenris-Ulven er sit Liv saa sikker som AsaThor" (Udkast C 2 til Nordens Mythologi, Thaning 1963, 163). Senere indser han åbenbart, at både Loke og guderne Thor og Brage repræsenterer stadier af ånd, mens jætterne og deres uhyrer er uånd og ikke skal indrømmes retttigheder.

I og med dette bliver den overordentlig og bemærkelsesværdigt lydhøre, men mytologisk set temmelig dådløse gud Heimdal også en vigtigere og interessantere figur $\mathrm{i}$ asadramaet end tidligere antaget. Heimdal er naturligvis "Udtrykket for den Vidskab og Forstand, der ikke spotter, bestrider eller forraader, men forsvarer Aandens og Poesiens Verden, og staaer derfor fiendtlig ikke blot mod Jetterne, de aabenbare Aands-Foragtere, men ogsaa mod Hinkeren imellem Begge, der i Grunden er af Jette-Byrd, og ender derfor med at blive Asernes Forræder: den falske Viismand Loke" (US V, 672). Hinkeren hentyder til 1 Kong 18.21, hvor Elias udtaler sig om jødernes vaklen mellem Herren (Jehova) og Baal. Det er et vigtigt træk i Heimdals mytologiske placering, at "Heimdal og Loke skal i Ragna-Roke drages saa længe, til de fældes Begge" (dvs. de slår hinanden ihjel i en af Ragnaroks symmetriske tvekampe). Det besegler, "at Heimdal er Forstanden paa Asernes Side, ligesom Loke paa Jetternes, og erindrer om, at al vor Erkiendelse hernede, selv den rette, skal som umoden affalde" (US V, 675) - måske et skjult citat fra Åb 6,13 om figentræets frugter. Heimdal vogter gyngebroen (Bifröst), som via den synlige regnbue afbilder "den usynlige Bro mellem Himlen og Jorden, mellem Aandens og Legemets Verden, som Billed-Sproget slaaer, og Forstanden skal forsvare" (US V, 675).

Loke er prototypen på "Al den Kløgt, der sig som Snogen / Snoer imellem Krop og Aand" (Grundtvigs digt "Nordens Aand", 1834, US VIII, 47). I Brage-Snak, 1844, fortsætter Grundtvig sin specifikation af Loke: han er "Sjoelen i Øieblikket eller i den norvaerende Tid", eksempel på "den fri Virksomhed" i dette (US VIII, 661, 663). At Loke langtfra er en negativ djævleskikkelse for Grundtvig, fremgår af, at han kan tildele tre lødige danske forfattere som Holberg, Steffens og Baggesen Loke-træk (US VIII, 632, 577, 624). Mest velment gælder dette Baggesen, hos hvem Grundtvig allerede i 1818 fandt et "ualmindeligt Øie for Aand i det Hele"; han var en "Øieblikkets Lys-Plet" ( $D V$ IV, US III, 612 og 609). Et samtidigt udkast tillægger ham styrke, ikke “i Øiet, men i Øret og i Haanden" (Fasc. 180.1, 32 v). Omkring 1823 resulterer denne aktuelle henvisning i en utrykt karakteristik af Loke som den tvetydige fornuft i sproget og i mennesket, haltende på sit 
højeste historiske punkt "mellem Aandens og Kroppens Verden" (jf. Lundgreen-Nielsen 2007, 77).

"Rim-Brev til Nordiske Paarørende" arbejder med sin Loketolkning ikke i en tankeverden, hvor der kun er to modsatrettede kræfter: godt (aser, vaner) over for ondt (Loke, jætter). I teksten antager Grundtvig tre faktorer: jætterne $=$ materien, dyriskhed (de spiser og drikker, slås og bruger kræfter, udøver sex, samler rigdom i råstoffer), aser og vaner $=$ en oprindelig guddommelighed, nu og da plettet af for stor selvrådighed, Loke $=$ den hinkende og haltende fornuft, der dels redder guderne fra kalamiteter, han selv har konstrueret, dels bliver årsag til deres endelige fald. Han er både den verdenskloge ironiker og den fatale ulykkesfugl. Drillende vid og tvetydig fornuft er hans hjemmebane. I asamyternes lange løb er hans udtryk mere nuancerede end Thors hammerslag og Odins spydkast. Han skal overvåges, om fornødent tæmmes, men ikke bindes. I den forstand er han ikke farlig i tiden før Ragnarok. Loke er nødvendig i gudernes åndsliv og skal have ligeret med Thor og Brage. Han er en halvbroder til grækernes Prometheus, og den, der smedede myten om ham, har bestemt været inspireret af mere end "Tørve-Røg eller Kul-Damp" - ordene må ses som et forgrovet referat af Magnusens ovenomtalte tolkning af Loke som fortærende ild - nemlig af noget enten "Aandeligt eller Djævelsk, da det saae ud til Allehaande" (US V, 702). Usikkerheden om hans væsen er inspirerende. Loke er og skal også være en bestandig udfordring.

\section{Modtagelse}

Ingemann skriver en privat anmeldelse i et brev til Grundtvig 26. december 1832 og anfører bl.a., at "Rimbrevet maatte du helst have sat sidst i Bogen, som for dine fleste Læsere indeholder Nøglen dertil" (Grundtvig 1882, 139); imod den enfoldige fejllæsning, at fortalens sølvbrud (dvs. hans muse for nordisk mytologi 1808-32) skulle være Lise Blicher, har Grundtvig "maaske vel betænkt sat en Skildvagt i Rimbrevet" (141). De to venners debat fortsætter til 7. februar 1833 (til og med 149). A. G. Rudelbach tilbyder fra Glaucha at oversætte værket til tysk og er endog begyndt at studere islandsk for at kunne gøre fyldest ( $B G$ II, 223). Det blev der dog intet af.

I samtiden anmeldtes værket ikke i Danmark (jf. Rønning 1912, 85-86) før af Christian Flor i Fr. Barfods tidsskrift Brage og Idun, I.1, 1839 (skrevet 1835, Ægidius 1985, 155). Det sker på den usædvanlige og interessante baggrund, at Flor som personlig ven af Grundtvig har drøftet sin anmeldelse med ham og derved har fået vished for, at han i sin gennemgang har truffet Grundtvigs mening på en prik (156). Flor lod den optrykke som selvstændig pjece i 1865 , let bearbejdet sprog- 
ligt og med nye fodnotehenvisninger til Grundtvigs Grask og Nordisk Mythologi for Ungdommen, 1847 (Flor 1865). "Rim-Brev" er lige nævnt i 1839, men slet ikke behandlet.

Lidt senere kaldte historikeren og historiografen Johannes Steenstrup rimbrevet fra 1832 for uheldigt (uden begrundelse) og fandt, at "Grundtvig er bleven betydelig lærdere end hin første Gang [dvs. 1808], men desværre er det gaaet med dette Arbejde som med Grundtvigs øvrige Virken, han, som var saadan fortrinlig Vækker og Kalder, blev dunkel og ofte mat, naar det hele skulde udarbejdes i System" (Steenstrup 1889, 51).

\section{Forskning}

En af de første undersøgelser af Grundtvigs forfatterskab, som bygger på videnskabelige studier og arkivforskning, er F. Rønnings monografi N. F. S. Grundtvig. Et bidrag til skildring af dansk åndsliv $i$ det 19. århundrede, hvor Nordens Mythologi karakteriseres i bind III.2 (Rønning 1912, 69-85). Det grundlægger vist en tradition i Grundtviglitteraturen for, at "Rim-Brev til Nordiske Paarørende" citeres for en lille håndfuld $\mathrm{nu}$ efterhånden klassiske verslinjer sidst $\mathrm{i}$ digtet, men ellers lades upåagtet og ukommenteret, som om alt andet var umiddelbart forståeligt (se fx Bang 1932, 59-61, Toldberg 1950, 132, 158, 291- 292, Baagø 1955, 14-16, Bredsdorff 1969, 37-38, Albeck 1971, 29, Borum 1983, 53-57, Grell 1992, 110-112, Auken 2005, 516$520,524)$.

Højskoleforstander Holger Begtrup udgav i 1907 teksten med forklarende Oplysninger neden under hver side (Begtrup 1907, 106-128). Desværre blev han så godt som hele tiden på et venligt genfortællende plan med overspringelse af de vanskelige problemer. Begtrup oversatte kort sagt rimbrevets broget sammensatte gruppe af symboler og den kollage, de udgjorde, til entydigt abstrakte tegn, uden at bryde sig om vekselvirkningen mellem dem eller de skiftende nuancer. Det bevirker, at det særprægede digt bliver gjort alment og uanskueligt. Guld fx betyder "Livets ædle Malm" og stål "det ydre Middel i Haandens Verden“ (Begtrup 1907, 109). En Phaëton-heliade-hentydning i "Havsens Bund" (v. 10) udlægges håndfast som "Tidens Strøm, Historiens Hav" (110), Fenris-ulven som "den vilde, dyriske Drift" (128), verdenstræet som "Slægtens Stamtræ" (119). I sjældnere tilfælde poetiserer Begtrup uden belæg Grundtvig, fx når "Skin i Odins Hald" (v. 106) forklares som en (forkastelig) identifikation af "Ærens Borg" med en "solbeskinnet Sky" (119), og når "seile der' egen Sø" (v. 169) omskrives til, at jætterne får lov at "tumle i Mørkets Moser" (123). Det er ligeledes videredigtning ud over tekstens ordlyd, når den enkle glose "Folk" (v. 104) gengives som "Mennesket af Gudeæt" (118). 
Grundtvigs beskrivelse af sværdet Tirfings mulige opdukken i den bælgmørke nat under gnister (v. 63) - og i kilden Heiðreks saga også andre ildfænomener (jf. $P S$ I, 465, 467, 468-469, 472) - kommenteres som en tilbagegang til "Hedenskabets Mørke" (115, fremhævet her). Det konkrete (høst)gilde i Ægers sal (v. 127) siges at betyde, at "Mindets Højsal (den historiske Højskole) bliver prydet med Heltenes Lavrbær" (120). Videre forklarer Begtrup Grundtvigs neutrale ord "Borge" og "skyhøie Bjerge" (v. 233) som "Ordets Højsale" og "Synernes Himmelbjerge" (127), og i udtrykket om åndslivets frie hav, der hæver sig over, hvad hænder kan nå (v. 235), øjner han "den nordiske Højskole" (127). Begtrups indtænkning af en kommende folkehøjskole får ham også til at se romer- og latinhad, hvor der ikke er sikkert vidnesbyrd om det hos Grundtvig. De gudebespottende jætter à la Hrungner (v. 143-156) tillægges ubegrundet den "romerske Uaand" (122), og Lethe-flodens glemselsstrøm (v. 170) håbes at være endemål for deres latinske "døde 'Klassikere"" (123), ørnens udsigt fra Ygdrasills top (v. 236) foreslås, dog med et spørgsmålstegn, henlagt til "Roms Kapitolium" (127). Det Grundtvigske ord "Dødbideri" fra de noget senere skoleskrifter (1836 ff.) bliver en kommentar (116) til Hels mulige regimente i Norden (v. 69-70). Også Begtrups noter om Loke er mindre nuanceret end Grundtvigs vurdering af figuren: Loke repræsenterer "Jættekløgten" (126), er den "aandelige Ophavsmand" til en radikal lære, "Talsmanden for Dybets Kræfter" (127), han tilhører "Mørkets Aander" og er selv "den ondskabsfulde Mørkets Aand" (128). Det er faktisk mere Magnusen end Grundtvig. I rimbrevet begrundes Lokes åndsfrihed med, at det kun er jætter, som fængsler det mundtlige ord (v. 244), og altså ikke aser eller ordentlige mennesker - det forstår Begtrup med ombytning af grundled og genstandsled som, at "kun det frie Ord kan binde Mørkets Aander" (128). Her cementeres en dualisme, Grundtvig ikke har gjort til sin formel for Lokes karakter og funktion. Også Lokes ord er nemlig vinget som tegn på åndsliv, og han "bruger Mund" i en anden mening end den, der gælder hans glubske ulvesøn.

Dristig, men også harmløsere er Begtrups sammenstilling af de mytologiske skikkelser Loke (v. 145-146), Thor (v. 180), Frej (v. 187196) med henholdsvis Holberg (122), Grundtvig og Ingemann (123) så kunne Balder (v. 197-198) såmænd også have været den døde Johannes Ewald. Men den slags noter ændrer Grundtvigs universelle perspektiv til snævrere dansk litteraturhistorie. Endelig skal hertil føjes nogle tvivlsomme eller rent ud forkerte gæt fra kommentatorens side. Det er hans generelle problem, at han ikke ænser de mytologiske og episke sammenhænge, Grundtvig har hentet sine enkeltheder fra, og 
simpelthen er uinteresseret i Grundtvigs kilder, skønt Nordens Mythologi er fyldt med fodnoter om og med dem.

Holger Begtrup er en så fortjent Grundtvig-forsker og Grundtvigudgiver, at disse velmente fejltrin sagtens kan tilgives ham. Hans generelle beskrivelse af tekstens virkning vidner om en god oplevelse og er samtidig typisk for de friheder, forkyndende højskolelærere på dette tidspunkt tager sig:

Der er Vaarliv og Vestenvind i dette Rimbrev. Isen er ved at bryde op i de danske Sunde, hvor den længe har ligget saa fast, at man næsten kunde tvivle om, at der var levende Vande derunder. Men nu brager og klirrer de brudte Flager, som skrues op paa Stranden, mens de forløste Bølger atter rører sig frit for Strøm og Vind, toppes med Skum og spiller i Solens Glans. Over den friske Sø stævner Grundtvig hjem for god Bør fra Englands Hav. Og da han er landet i Kongens København, skriver han en Bog, som er fuldt af det Vejr, han har indaandet. (Begtrup 1907, 107)

Begtrups appetitvækkende vision hjælper dog ikke de læsere stort, der mangler Grundtvigs mytologiske og historiske horisonter. Helge Toldberg døde desværre i 1964 som kun 50-årig fra en bredt anlagt undersøgelse af Grundtvigs forhold til nordisk mytologi. Heller ikke den udførligste moderne drøftelse af teksten (Christensen 1987, 204214 , jf. Christensen 1998, 258) går meget ind på rimbrevets flueøjede billedsprog. I den nyeste og mest dybtborende behandling af tilblivelsen af Nordens Mythologi, Kaj Thanings disputats, synes det at være en pointe, at "Rim-Brev til Nordiske Paarørende" nævnes så lidt som muligt (Thaning 1963, 253, note 5 til s. 163, og 285, hvor det figurerer med genrebetegnelsen "prologen"). I populært formidlende eller ligefrem romanagtige sammenhænge går det naturligvis ikke bedre. Der er behov for nøgtern oplysning.

\section{Nyd, som du nemmer!}

"Rim-Brev til Nordiske Paarørende" tilhører den del af Grundtvigs versdigtning, som er interessant $i$ kraft af tankerigdom udtrykt i et broget og indforstået billedsprog med en stor mængde associationer. Dets genremæssige pårørende er fx "Udby Have", "Strandbakken ved Egeløkke", Roskilde-Riim, "Skjalde i den usle Døgn!", "Ragna-Roke", "Nordens Aand" og "Dansk Ravne-Galder". Æstetisk måler det sig ikke med hans bedste indsats på feltet, det virkeligt mageløse kvad Nyaars-Morgen, 1824 - men hvad gør overhovedet det? Det kan heller ikke bære vand mod den fortjente popularitet, Grundtvigs verdslige og kristelige lyrik har vundet $\mathrm{i}$ langt enklere stilarter. Rimbrevet kræver medarbejde af læseren og aftvinger respekt, men er ikke af den slags poesi, som læres udenad, end sige synges. En god måde at nærme sig 
det på er langsomt at læse det højt, lade det få den lydelige form, Grundtvig navnlig siden 1825 havde dyrket og talt om.

\section{Forkortelser}

$B G$ I-II: Georg Christensen og Stener Grundtvig (udg.) (1924-26), Breve fra og til N. F. S. Grundtvig, 1807-1872, bind 1-2, København.

Fasc.: Fascikel, dvs. håndskriftskapsel i N. F. S. Grundtvigs Arkiv på Det Kongelige Bibliotek.

GSkv I-II: K. E. Bugge (udg.) (1968), Grundtvigs skoleverden i tekster og udkast, bind 1-2, København.

MM: Svend Grundtvig (udg.) (1877), Mands Minde 1788-1838. Foredrag over det sidste halve Aarhundredes Historie, holdte 1838 af Nik. Fred. Sev. Grundtvig, København.

Nordens Mythologi: N. F. S. Grundtvig (1832), Nordens Mythologi eller Sindbilledsprog, København.

PS I-IX: Svend Grundtvig et al. (udg.) (1880-1930), N. F. S. Grundtvigs Poetiske Skrifter, bind 1-9, København.

Resen 1665: Anthony Faulkes (ed.), Edda Islandorum. Völuspá. Hávamál. P. H. Resen's editions of 1665, Reykjavík, 1977.

Resens Voluspa 1665: P. H. Resen (udg.), Philosophia antiqvissima NorvegoDanica dicta Voluspa, Havniæ, 1665.

SJ I-IV: Steen Johansen (1948-54), Bibliografi over N. F. S. Grundtvigs Skrifter, bind 1-4, København.

US I-X: Holger Begtrup (udg.) (1904-09), Nik. Fred. Sev. Grundtvigs Udvalgte Skrifter, bind 1-10, København.

$V U$ I-X: Georg Christensen og Hal Koch (udg.) (1940-49), N. F. S. Grundtvigs Veerker i Udvalg, bind 1-10, København.

\section{Litteraturliste}

\section{Voerker af N. F. S. Grundtvig}

Begtrup, Holger (udg.) (1904-09), Nik. Fred. Sev. Grundtvigs Udvalgte Skrifter, bind 1-10, København.

Bugge, K. E. (udg.) (1968), Grundtvigs skoleverden i tekster og udkast, bind 1-2, København.

Bugge, K. E. og Nielsen, Vilhelm (udg.) (1983), N. F. S. Grundtvig: Statsmaessig Oplysning. Et udkast om samfund og skole, København.

Christensen, Georg og Grundtvig, Stener (udg.) (1924-26), Breve fra og til N. F. S. Grundtvig, 1807-1872, bind 1-2, København.

Christensen, Georg og Koch, Hal (udg.) (1940-49), N. F. S. Grundtvigs Varker i Udvalg, bind 1-10, København.

Fabricius, Jørgen (udg.), "N. F. S. Grundtvigs breve til hans hustru under Englandsrejsen 1843" i Grundtvig-Studier 1952, 39-71. 
Grundtvig, F. L. (udg.) (1891), "N. F. S. Grundtvigs Breve fra England til Dronning Karoline Amalie. 1843" i Nygård, Fr. og Schrøder, L. (red.), Danskeren. Tidsskrift for Land og By, bind 5, Kolding, 195-220.

Grundtvig, N. F. S., Fasc. 180.1, 251, 256, 269.11, 388.135-136, 389.5.

- (1807), "Om Religion og Liturgie" i US I, 136-173.

- (1807), "Et Par Ord i Anledning af det forkyndte Sørgespil: Signe" i $N y$ Minerva 1807, 249-263.

- (1808), "Maskeradeballet i Dannemark 1808" i US I, 225-240.

- (1810), Idunna. En Nytaarsgave for 1811, København.

- (1810), "Sværdet Tirfing. En Skemtesaga" i PS I, 447-492.

- (1810), "Vækker-Sang" i US II, 42-44.

- (1812), "Kort Begreb af Verdens Krønike i Sammen-hæng” i US II, 167422.

- (1814), "Roskilde-Riim"' i US II, 427-608.

- (1814), "Roskilde-Saga" i US II, 610-693.

- (1816), "Et Blad af Jyllands Rimkrønike" i US III, 196-247.

- (1817), "Paaske-Lilien" i US III, 438-440, 458-459.

- (1817), Udsigt over Verdens-Krøniken fornemmelig $i$ det Lutherske Tidsrum, København.

- (1820), Bjowulfs Drape. Et Gothisk Helte-Digt fra forrige Aar-Tusinde af Angel-Saksisk paa danske Riim, København.

- (1822), "Min Moder" i US IV, 205-209.

- (1832), "Nordens Mythologi eller Sindbilled-Sprog historisk-poetisk udviklet og oplyst" i US V, 378-767.

— (1833, 1836, 1843-56, med Tillæg 1869), "Haandbog i Verdens-Historien. Efter de bedste Kilder. Et Forsøg", bind 1-3, i US VI, 7-692 og US VII, 5-704.

- (1834), "Nordens Aand" i US VIII, 40-51.

- (1834), "Den danske Rim-Krønike" i Den Nordiske Kirke-Tidende for 17.31.august 1834, sp. 549-558, 568-576, 577-591.

- (1834), "Tids-Aanden" i PS VI, 54-74.

- (1836), "Det Danske Fiir-Kløver eller Danskheden partisk betragtet" i GSkV II, 7-56.

— (1838), "Sværdet Tirfing. (efter Hervors Saga)" i PS I, 493-537.

- (1838), Nordiske Smaadigte, Christiania.

- (1844), "Skov-Hornets Klang mellem Skamlings-Bankerne" i US IX, 1938.

- (1844), "Brage-Snak om Græske og Nordiske Myther og Oldsagn for Damer og Herrer" i US VIII, 493-788.

- (1847), Graesk og Nordisk Mythologi for Ungdommen, København.

- (1848-51), Danskeren. Et Ugeblad, bind 1-4, København.

- (1849), "Nordens Guld" i PS VI, 41-51.

- (1851), “Ægers-Gildet i Engeland" i PS VII, 443-454.

- (1860), Christenhedens Syvstjerne. Et Kirkeligt Saga-kvad, København.

- (1864), Nordens Myther i PS IX, 137-265.

Grundtvig, Stener m.fl. (udg.) (1920), N. F. S. Grundtvigs Englandsbreve til hans Hustru, København. 
Grundtvig, Svend (udg.) (1875), Krønnike-Rim med Indledninger og Oplysninger af Nik. Fred. Sev. Grundtvig. Tredje Udgave, København.

- (udg.) (1877), Mands Minde 1788-1838. Foredrag over det sidste halve Aarhundredes Historie, holdte 1838 af Nik. Fred. Sev. Grundtvig, København.

— et al. (udg.) (1880-1930), N. F. S. Grundtvigs Poetiske Skrifter, bind 1-9, København.

- (udg.) (1882), Grundtvig og Ingemann. Brevvexling 1821-1859, København.

Schrøder, L. (udg.) (1888), Christian Molbech og Nikolai Frederik Severin Grundtvig. En Brevvexling, samlet af Chr. K. F. Molbech, København.

\section{Varker af andre forfattere}

Albeck, Gustav (1953), Omkring Grundtvigs Digtsamlinger. Studier $i$ Grundtvigs lyriske Forfatterskab 1808-16, København.

- (1971), "Grundtvigs rimbreve" i Grundtvig-Studier 1971, 7-30).

- (1979), N. F. S. Grundtvigs Dag- og Udtogsbøger, bind 1-2, København.

Arlaud, A. (udg.) (1891), Jens Baggesens Poetiske Skrifter, II. Riimbreve og Poetiske Epistler. Første Samling 1784-1808, København.

— (udg.) 1903, Jens Baggesens Poetiske Skrifter, V. Blandede Digte. Anden Samling 1803-1814, København.

Auken, Sune (2005), Sagas spejl. Mytologi, historie og kristendom hos N. F. S. Grundtvig, København.

Baagø, Kaj (1955), "Grundtvig og den engelske liberalisme" i GrundtvigStudier 1955, 7-37.

Bang, J. P. (1932), Grundtvig og England. Studier over Grundtvig, København.

Barfod, Frederik (1839-42), Brage og Idun, et nordisk Fjardingårskrift, bind 1-5 (i 9 hefter), København.

Bech, Henr. (1878), Gunni Busck, et Levnedsløb i en Prastegaard, 2. udg., København.

Begtrup, Holger (1907), "N. F. S. Grundtvig: Rim-Brev til Nordiske Paarørende med Oplysninger" i Tidsskrift, III, København, 106-128.

Borum, Poul (1983), Digteren Grundtvig, København.

Bredsdorff, Morten (1969), "Grundtvig og Shakespeare" i Grundtvig-Studier 1969, 33-46.

Brix, Hans m.fl. (udg.) (1916), Johannes Ewalds Samlede Skrifter, III, København.

Christensen, Bent (1987), Fra drøm til program. Menneskelivets og dets verdens plads og betydning $i N$. F. S. Grundtvigs kristendomsforståelse fra Dagningen i 1824 over Opdagelsen i 1825 til Indledningen i 1832, København.

- (1998), Omkring Grundtvigs Vidskab. En undersøgelse af N.F. S. Grundtvigs forhold til den erkendelsesmossige side af det kristeligt nødvendige livsengagement, København.

Faulkes, Anthony (ed.) (1977), Edda Islandorum. Völuspá. Hávamál. P. H. Resen's editions of 1665, Reykjavík. 
Flor, Christian (1839), "Anmeldelse af Grundtvigs Nordens Mythologi, 1832" i Barfod, Fr. (red.): Brage og Idun, 1.1, 176-230.

- (1865), Kort Fremstilling af N. F. S. Grundtvigs mythologiske og historiske Betragtningsmåde. En Ledetråd, København.

Fortegnelse over N. F. S. Grundtvigs Bibliothek (1873), København.

Friis-Jensen, Karsten (udg.) og Zeeberg, Peter (overs.) (2005), Saxo Grammaticus, Gesta Danorum. Danmarkshistorien, bind 1-2, København.

Grell, Helge (1992), England og Grundtvig. Grundtvigs møde med England og dets betydning for hans forfatterskab, Århus.

Grundtvig, Svend (udg.) (1856), Danmarks gamle Folkeviser, II, København.

Grønbæk, Villiam (1951), Psykologiske tanker og teorier hos Grundtvig, København.

Hagen. L. C. (red.) (1832), Historiske Psalmer og Riim til Børne-Lardom, København.

Helgason, Jón (udg.) (1955-56), Eddadigte I. Völuspá Hávamál, II. Gudedigte, bind 1-2, København, Oslo, Stockholm.

Johansen, Steen (1951), "Om Grundtvig-udgaver" i Grundtvig-Studier 1951, 69-91.

- (1948-54), Bibliografi over N. F. S. Grundtvigs Skrifter, bind 1-4, København.

Kjems, Rud (2006), Runamo. Skriften der kom og gik, Århus.

Kjær, Iver og Kousgaard Sørensen, John (udg.) (1983), "Peder Syv: Danske Ordsproge", I, 1682, i Danmarks gamle Ordsprog, VII.1, København.

Kondrup, Johnny (udg.) (1996), Henrich Steffens: Indledning til philosophiske Foreloesninger, København.

Larsen, Martin (overs.) (1943-46), Den celdre Edda og Eddica Minora, bind $1-2$, København.

N. Lukman, N. (1944), "Vore Eddaoversættelser" i Gads danske Magasin 1944, 387-401.

Lundgreen-Nielsen, Flemming (1980), Det handlende ord. N. F. S. Grundtvigs digtning, litteraturkritik og poetik 1798-1819, bind 1-2, København.

— (1992), "Dragedukke, subst." i Ejskjær, I. m.fl. (red.), 80 Ord til Christian Lisse 12. januar 1992, 32-33.

- (1994), "Grundtvigs nordisk-mytologiske billedsprog - et mislykket eksperiment?" i Grundtvig-Studier 1994, 142-198.

- (2002), "Anders Sørensen Vedel og Peder Syv - To lærde folkeviseudgivere" i Lundgreen-Nielsen, Flemming og Ruus, Hanne (red.), Svøbt $i$ mår. Dansk folkevisekultur 1550-1700, 4. Lardom og overtro, København, 153-374.

- (2007), "Grundtvig og censuren" i Grundtvig-Studier 2007, København, 44-90.

Lyschander, C. C. (1622): Synopsis Historiarum Danicarum (...) Danske Kongers Slectebog, København.

Magnusen, Finn (Magnússon, Finnur) (udg.) (1818-28), Edda Samundar hinns fróda, bind 2-3 (i 3 Prisca veterum Borealium Mythologice Lexicon). 
- (overs.) (1821-23), Den celdre Edda. En Samling af de nordiske Folks aldste Sagn og Sange, ved Samund Sigfussøn kaldet hin Frode. Oversat og forklaret, bind 1-4, København.

- (1824-26), Eddalceren og dens Oprindelse eller nøjagtig Fremstilling af de gamle Nordboers Digtninger og Meninger om Verdens, Gudernes, Aandernes og Menneskenes Tilblivelse, Natur og Skjæbne i udførlig Sammenligning, saavel med Naturens store Bog, som med Grokers, Persers, Inders og flere gamle Folks mythiske Systemer og Troesmeninger, med indblandede historiske Undersøgelser over den gamle Verdens markvoerdigste Nationers Herkomst og aeldste Forbindelser, bind 1-4, København.

Nielsen, E. Brandt (1966), "Peter Nikolaj Skougaard, Grundtvigs mathematiske ven" i Grundtvig-Studier 1966, 7-38.

Oehlenschläger, Adam (1805), Poetiske Skrifter, II (heri “Aladdin eller den forunderlige Lampe"), København.

- (1807), Nordiske Digte (heri "Thors Reise til Jothunheim, et episk Digt i 5 Sange" og "Baldur hin Gode, et mythologisk Sørgespil"), København.

- (1819), Nordens Guder. Et episk Digt, København.

Petersen, Carl S. (udg.) (1923): Ludvig Holbergs Samlede Skrifter, VI.

Rothe, Tyge (1795), Jorden - efter kiendelig lagt Plan - en Verden for levende vellidende Veesener (I.1-2, dvs. det udkomne), København.

Rønning, F. (1912), N. F. S. Grundtvig. Et bidrag til skildring af dansk åndsliv $i$ det 19. århundrede, III.2, København.

- (1927), Grundtvig som toenker. Indledningen til "Nordens Mythologi" af 1832. Med en efterskrift, København.

Steenstrup, Johannes (1889), Historieskrivningen $i$ Danmark $i$ det $19^{\text {de }}$ Aarhundrede (1801-1863), København.

Stephanius, Stephanus (1645): Notce Vberiores in historiam Danicam Saxonis Grammatici, Sorø.

Thaning, Kaj (1963), Menneske først - Grundtvigs opgør med sig selv, bind 1-3, København.

Thorkelin, G. J. (1815), De Danorum Rebus Gestis Secul. III \& IV. Poëma Danicum Dialecto Anglosaxonica, København.

Toldberg, Helge (1950), Grundtvigs symbolverden, København.

- (1954), "Grundtvig og den danske rimkrønike" i Grundtvig-Studier 1954, 40-95.

- (udg.) (1961): Den danske rimkrønike, I. Ghementrykket 1495 med variantapparat, København.

Vedel, Anders Sørensen (overs.) (1575): Den Danske Krønicke som Saxo Grammaticus screff, København.

Vigfússon, G. og Unger, C. R. (udg.) (1860): Flateyarbók, I, Kristiania.

Vries, Jan de (1956-57), Altgermanische Religionsgeschichte, Zweite, völlig neu bearbeitete Auflage, bind 1-2, Berlin.

Ægidius, Jens Peter (1978), Vølvens spådom på dansk. En litteratur- og åndshistorisk undersøgelse (Studier fra Sprog- og Oldtidsforskning, nr. 294), København.

- (1985), Bragesnak. Nordiske myter og mytefortælling i dansk tradition (indtil 1910), Odense. 